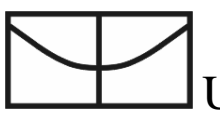

Universidade de Brasília - UnB

FACULDADE DE ECONOMIA, ADMINISTRAÇÃO, CONTABILIDADE E CIÊNCIA DA INFORMAÇÃO E DOCUMENTAÇÃO - FACE

PROGRAMA DE PÓS-GRADUAÇÃO EM ADMINISTRAÇÃO - PPGA

ADAM LUIZ ALVES BARRA

\title{
COMPATIBILIDADE DO REGIME JURÍDICO DO CONCURSO PÚBLICO FEDERAL COM A SELEÇÃO DE SERVIDORES POR COMPETENCIAS
}




\title{
COMPATIBILIDADE DO REGIME JURÍDICO DO CONCURSO PÚBLICO FEDERAL COM A SELEÇÃO DE SERVIDORES POR COMPETENCIAS
}

\begin{abstract}
Monografia apresentada ao curso de Gestão de Pessoas do Programa de Pós-Graduação em Administração da Faculdade de Economia, Administração, Contabilidade e Ciência da Informação e Documentação - FACE, da Universidade de Brasília - UnB, como requisito parcial para obtenção do título de Especialista em Gestão de Pessoas.
\end{abstract}

Orientador: Prof. Dr. Pedro Meneses

Brasília-DF

2009 
BARRA, Adam Luiz Alves.

Compatibilidade do regime jurídico do concurso público federal na seleção de servidores por competências. Adam Luiz Alves Barra.

Monografia - Pós-Graduação em Gestão de Pessoas.

Brasília-DF, Setembro de 2009.

Área de Concentração: Seleção de Pessoas - Concurso Público.

Orientador: Prof. Dr. Pedro Meneses.

1. Administração Pública. 2. Seleção de Pessoas por Competências. 3. Concurso Público. 


\section{AGRADECIMENTOS}

Agradeço, sobretudo, a Deus pelo dom inestimável da vida e pelo Seu imenso Amor de Pai que sempre me acompanha e me protege, dando sentido a tudo que faço.

À minha linda esposa, Shirley, minha musa inspiradora e melhor amiga, agradeço por ter me incentivado a ser perseverante, pela sua companhia e sua ajuda constante, fundamentais à conclusão desta monografia.

Aos meus pais, mesmo que fisicamente distantes, são presentes de Deus para mim, que com seu amor me proporcionaram a vida e, sabiamente, ensinaram-me a superar os momentos difíceis.

Aos meus queridos irmãos, pelo carinho e amizade, essenciais em cada momento e igualmente sentidos apesar das centenas de quilômetros que nos separam.

Ao meu orientador, Doutor Pedro Meneses, pela confiança depositada em mim ao aceitar me conduzir pelo polêmico tema deste trabalho monográfico. 


\section{RESUMO}

O presente estudo monográfico discute o uso da entrevista comportamental, um instrumento de seleção por competências, no atual regime jurídico do concurso público federal brasileiro. Buscou-se, a partir da análise da seleção de servidores por competência prevista legalmente na República Dominicana, verificar se um dos instrumentos de seleção utilizados por esse país é compatível com as normas e princípios que regem o concurso público federal. A pesquisa realizada foi de caráter documental, sendo os dados coletados submetidos à categorização e interpretação por meio da análise de conteúdo proposta por Bardin (2009). Os resultados obtidos indicaram que a utilização da entrevista comportamental em concursos públicos federais é juridicamente viável, não podendo ser igualada aos exames psicotécnicos, que aferem a aptidão mental do candidato, têm caráter exclusivamente eliminatório e constituem um requisito específico para a investidura em alguns cargos públicos.

1. Administração Pública. 2. Seleção de Pessoas por Competências. 3. Concurso Público. 


\title{
LISTA DE SIGLAS
}

\author{
APF - Administração Pública Federal \\ CF/88 - Constituição da República Federativa do Brasil de 1988 \\ CLAD - Centro Latino-americano de Administração para o Desenvolvimento \\ ENAP - Escola Nacional de Administração Pública \\ EUA - Estados Unidos da América \\ OCDE - Organização para a Cooperação e Desenvolvimento Econômico \\ SRH - Secretaria de Recursos Humanos \\ STF - Supremo Tribunal Federal \\ STJ - Superior Tribunal de Justiça
}




\section{SUMÁRIO}

\section{AGRADECIMENTOS} iv

RESUMO $\mathbf{v}$

LISTA DE SIGLAS vi

1 INTRODUÇÃO 8

2 REFERENCIAL TEÓRICO 11

2.1 Administração Pública___ 11

2.1.1 Conceitos

2.1.2 Administração Pública e Reforma 14

2.1 .3

Administração Pública Gerencial e Gestão por Competências 20

2.2 Seleção de Pessoas 22

2.2.1 Origem e evolução

2.2.2 Instrumentos de seleção 23

2.2.3 Seleção por competências 25

2.3 Concurso Público 34

3 METODOLOGIA 35

3.1 Tipo de pesquisa 40

3.2 Corpus da análise documental 40

3.3 Procedimento de coleta de dados 40

3.4 Análise de dados 41

4 RESULTADOS 41

42

4.1 Seleção de servidores públicos por competências ___ 42

4.2 Normas de seleção de servidores públicos da APF ___ 44

4.3 Jurisprudência sobre seleção de servidores públicos___ 47

5 ANÁLISE DOS RESULTADOS__ 49

6 CONCLUSÃO

7 REFERÊNCIAS _

8 ANEXOS

8.1 Lei n ${ }^{\circ} 41$ de 04/01/2008 (República Dominicana)___ 57

8.2 Decreto $n^{\circ} 524$ de 21/07/2009 (República Dominicana) __ 95 


\section{INTRODUÇÃO}

O papel do Estado nas sociedades contemporâneas é - sob a ótica da governabilidade, do progresso econômico e da redução da desigualdade social - fundamental para se atingir níveis crescentes de bem-estar coletivo. Para se obter um melhor Estado, instrumento indispensável para o desenvolvimento dos países, a profissionalização dos agentes públicos é uma condição indispensável.

As políticas de seleção de pessoas da Administração Pública se caracterizam como uma parte estratégica na consecução desse objetivo. São elas que podem garantir o acesso por meio do concurso público em condições isonômicas, de acordo com princípios como competitividade, legalidade e eficiência, selecionando servidores públicos que atendam com objetividade e efetividade as demandas que a sociedade os apresenta.

A origem do estudo de processos de seleção de pessoas confunde-se com a definição da Administração e da Psicologia como ciências autônomas, o que demonstra a importância desse tema para esses ramos do conhecimento.

Essa importância tornou-se ainda maior em razão das transformações intensas geradas pelo acirramento da competitividade em um mercado global. A sofisticação dos processos laborais, as mudanças nas relações de trabalho, nas competências essenciais das organizações e no perfil do profissional requerido estão provocando alterações nos objetivos, técnicas e aplicações dos processos de recrutamento e seleção (CARVALHO; PASSOS; SARAIVA, 2008).

Os novos instrumentos e técnicas de seleção passaram a ser amplamente utilizados pelas organizações privadas, pois, para garantir sua sobrevivência no contexto atual, substituíram suas estruturas burocráticas por modelos mais flexíveis de gestão. A Administração Pública Brasileira, contudo, apesar das reformas estruturais iniciadas na década de 1990, mantém as mesmas práticas de seleção de servidores utilizadas na década de 1950.

Paralelamente, a crise de desemprego constante e o sonho de ocupar um cargo público estável levam milhares de brasileiros a despender tempo e dinheiro na preparação para ingressar no serviço público. Em contrapartida, a maioria dos concursos públicos 
resume-se a avaliações realizadas para auferir conhecimentos de candidatos, dentre os quais são escolhidos aqueles com as maiores notas.

A grande demanda por uma vaga na Administração Pública Federal (APF) encontrou resposta em uma forte "indústria" especializada em treinar os indivíduos para responder provas rigorosamente centradas nos conteúdos programáticos do cargo público vago. E os órgãos que promovem os concursos já sentem o impacto da aprovação de um candidato que obteve sucesso na prova, mas não consegue realizar o seu trabalho conforme era esperado.

Urge, portanto, o aprimoramento dos objetivos, técnicas e aplicações dos processos de recrutamento e seleção de servidores públicos, não apenas para identificar os candidatos mais competentes e adequados para atender as necessidades da APF, mas também para garantir condições isonômicas de seleção.

O descaso com a complexidade do concurso público leva a Administração Pública a cometer sérios equívocos que prejudicam tanto os candidatos quanto ela própria. Um concurso público realizado de forma imprópria reprova injustamente excelentes candidatos e seleciona pessoas que não atendem às necessidades estratégicas do Estado, podendo provocar, por décadas, gasto público ineficiente ao remunerar um servidor desprovido das competências necessárias à Administração Pública.

Portanto, selecionar servidores públicos com base em suas competências, e não somente de acordo com seus conhecimentos, pode aprimorar o instituto do concurso público e suprir a Administração Pública com as competências necessárias para o alcance de seus objetivos estratégicos de forma mais eficiente.

Uma preocupação, contudo, perturba diversos dirigentes de recursos humanos dos órgãos e entidades da APF: essa forma mais estratégica de selecionar servidores desrespeita a legislação atual, muitas vezes pouco flexível e construída com base em paradigmas de meados do século passado?

Um exemplo dessa preocupação pode ser localizado nas bases do Planejamento Estratégico e Tático da Fundação Universidade de Brasília, de outubro de 2007. Identifica-se nesse documento o seguinte desafio estratégico da Área de Recursos Humanos: "elaborar propostas visando a racionalizar a legislação federal sobre recursos humanos" (UNIVERSIDADE DE BRASÍLIA, 2007).

Assim, com base no contexto acima descrito, verifica-se a importância de se estudar como o Estado Brasileiro pode selecionar melhor seus servidores. Percebe-se, contudo, que os 
estudos sobre o tema estão concentrados seja na área de Gestão de Pessoas, analisando a efetividade das técnicas de seleção, seja na área de Direito, verificando a adequação do concurso público aos princípios normativos que o regem.

Tendo em vista o conhecimento jurídico do pesquisador e sua atuação profissional no Sistema de Pessoal Civil da Administração Federal (SIPEC), a divulgação do resultado desta pesquisa auxiliará no diálogo entre as duas áreas referidas, contribuindo para ampliar o conhecimento dos dirigentes de recursos humanos sobre os riscos jurídicos da adoção da seleção por competências em concursos públicos federais.

Dessa forma, objetivamente, o presente estudo se propôs a responder o seguinte problema de pesquisa: a substituição da avaliação de conhecimentos pela avaliação de competências na seleção de servidores para a Administração Pública Federal é compatível com o atual regime jurídico do concurso público?

Para tanto, a pesquisa realizada foi de caráter bibliográfico e documental, sendo os dados coletados submetidos à quantificação e interpretação por meio da análise de conteúdo proposto por Bardin (2004).

O objetivo geral do estudo consistiu em:

$\checkmark$ Analisar a compatibilidade entre a avaliação de competências na seleção de servidores para a Administração Pública Federal e o atual regime jurídico do concurso público.

Os objetivos específicos buscaram:

$\checkmark$ Identificar o uso ou a previsão legal de instrumentos de seleção de servidores públicos por competências na Administração Pública de outros países;

$\checkmark$ Identificar se existem, nas normas que regem atualmente o concurso público para ingresso de servidores na Administração Pública Federal do Brasil, óbices jurídicos à utilização de um dos instrumentos de seleção por competências identificado;

$\checkmark$ Identificar, em decisões do Superior Tribunal de Justiça (STJ) e do Supremo Tribunal Federal (STF) referentes à aplicação de normas do concurso público federal, óbices jurídicos à utilização do instrumento identificado na seleção por competências de servidores públicos federais. 


\section{REFERENCIAL TEÓRICO}

Apesar de restrita a produção acadêmica e científica sobre o tema desta pesquisa, o presente capítulo analisa alguns temas correlatos: a administração pública, a seleção de pessoas e o regime jurídico do concurso público.

\subsection{Administração Pública}

\subsubsection{Conceitos}

Conceituar a expressão administração pública é uma tarefa complexa em razão da diversidade de sentidos que o termo apresenta e das diferentes áreas em que se desenvolve a atividade administrativa (MATIAS-PEREIRA, 2008).

Administração é "o ato, processo ou efeito de administrar", enquanto o adjetivo público qualifica algo como sendo "(i) relativo ou pertencente a um povo, a uma coletividade; (ii) relativo ou pertencente ao governo de um país, estado, cidade etc (...)." (HOUAISS, 2001, p. 86 e p. 2330$)$.

Uma das formas mais simples de definir administrar é "executar, de forma contínua e virtuosa, o processo administrativo"; processo este que resulta da interação constante de quatro elementos fundamentais: planejamento, organização, direção e controle. Elementos que, por sua vez, podem ser decompostos em inúmeros processos menores para que sejam definidas as várias atividades envolvidas no processo administrativo ou gerencial (BERGUE, 2007, p. 17).

Partindo do pressuposto que a administração é uma atividade exercida por quem não é senhor absoluto, Di Pietro (2004) defende que a administração, seja ela privada ou publica, depende de uma vontade externa - individual ou coletiva - vinculada ao princípio da finalidade, devendo ser útil ao interesse a ser satisfeito pelo administrador.

Rosenbloom afirma que dificilmente se conseguirá aludir e englobar todas as atividades e áreas de atuação da Administração Pública em um conceito de sentido estrito. Portanto, define-a amplamente "como a actividade necessária para que a vontade de um 
governo alcance determinados propósitos ou objectivos, em nome da colectividade" (ROSENBLOOM apud FERRAZ, 2008, p. 15).

Ainda que a atividade administrativa corresponda a um número incontável de ações relacionadas ao Estado, dificultando o esclarecimento da expressão administração pública, essa atividade apresenta - pela própria natureza da administração - dois atributos comuns. $\mathrm{O}$ primeiro deles é a subordinação ao poder político (relacionado aos poderes de decisão e de comando do Governo) e à ordem jurídica (característica do Estado de Direito), que determinam ou especificam os fins que a atividade administrativa deve atingir. Em segundo lugar, o atributo de ser executiva, tanto porque acata uma escolha ou norma anterior, quanto em razão de dar continuidade à norma, intervindo para concretizar os interesses e os objetivos públicos já fixados. Esses atributos contribuíram para que a administração pública fosse identificada, essencialmente, como uma função ou atividade-fim (condicionada a um objetivo), e como organização, isto é, como uma atividade voltada para assegurar a distribuição e a coordenação do trabalho dentro de um escopo coletivo (BOBBIO; BOBBIO; MATTEUCI; PASQUINO, 2003; FERRAZ, 2008).

Somado a essa identificação como função e organização, mesmo que não a defina em termos estritos, o conceito utilizado por Matias-Pereira esclarece o que a expressão administração pública engloba: "todo o sistema de governo, todo o conjunto de idéias, atitudes, normas, processos, instituições e outras formas de conduta humana, que determinam: (a) como se distribui e se exerce a autoridade política; (b) como se atendem aos interesses públicos”. Genericamente, pode-se afirmar ainda que a Administração Pública responde - em sua missão de coordenar e implementar políticas públicas - tanto às necessidades e características dos cidadãos, quanto às políticas definidas pelo Governo e às normas constitucionais do Estado de Direito (MATIAS-PEREIRA, 2008, p. 175; e MOZZICAFREDDO apud FERRAZ, 2008).

Considerando que o objeto do presente estudo relaciona-se com a seara jurídica e que não foi localizada uma definição de administração pública em sentido estrito na Ciência da Administração, parte-se para a localização de um conceito estrito de administração pública na Ciência do Direito.

Visando delimitar seu objeto de estudo, o Direito alcança uma definição mais estrita de administração pública a partir da concepção de função administrativa. Função essa que é considerada uma função pública por ser uma atividade exercida com a finalidade de alcançar os interesses públicos, interesses da sociedade como um todo; em oposição aos interesses 
privados, que são oriundos das atividades dos particulares e governados pela autonomia da vontade. Dentre as funções públicas, distingue-se das funções legislativa e jurisdicional, que se ocupam, respectivamente, do estabelecimento de regras gerais e abstratas (leis) e da solução de conflitos de interesses por meio da aplicação da lei ao caso concreto - ainda que de forma coativa, quando as partes não o façam espontaneamente (DI PIETRO, 2004; MELLO, 2008).

Caracterizada a função administrativa, ela é analisada sob as perspectivas objetiva e subjetiva. Se a função administrativa for considerada a partir da natureza da atividade exercida, está se referindo ao seu sentido objetivo (material ou funcional), enquanto se for encarada com base em quem a exerce, refere-se ao seu sentido subjetivo (formal, orgânico ou estrutural).

Partindo de seu atributo como organização, a expressão administração pública confunde-se com o conceito de serviço público. Para elaborar um conceito estrito de serviço público, Di Pietro (2004, p. 99) distingue-o das demais atividades administrativas (polícia, fomento e intervenção) e define-o como "toda atividade material que a lei atribui ao Estado para que a exerça diretamente ou por meio de seus delegados, com o objetivo de satisfazer concretamente às necessidades coletivas, sob regime jurídico total ou parcialmente público".

Assim, como conceito de administração pública que considera os sentidos objetivo e subjetivo, facilmente relacionados aos atributos da atividade administrativa (função e organização), apresenta-se o seguinte:

A administração pública pode ser definida objetivamente como a atividade concreta
e imediata que o Estado desenvolve para a consecução dos interesses coletivos e
subjetivamente como o conjunto de órgãos e de pessoas jurídicas aos quais a lei
atribui o exercício da função administrativa do Estado (MORAES, 2005, p. 294).

Com vistas a auxiliar na distinção entre administração pública e Governo, alguns juristas a caracterizam com base na idéia de que administrar compreende planejar e executar. Em sentido amplo, sob o aspecto subjetivo, dividem-na em órgãos governamentais (supremos ou constitucionais) - responsáveis por traçar os planos de ação, dirigir, comandar - e órgãos administrativos (subordinados ou dependentes) - aos quais incumbe executar os planos governamentais. Já em sentido objetivo, a função política traça as diretrizes governamentais e a função administrativa as executa. Porém, considerada em sentido estrito, apenas os órgãos administrativos e a função administrativa estariam compreendidos na administração pública (DI PIETRO, 2004). 
Dessa forma, verifica-se que os conceitos de serviço público e função administrativa admitem uma definição mais estrita da expressão administração pública, na medida em que caracterizam as atividades que ela desenvolve na consecução dos interesses públicos definidos pelas normas estatais e conseguem distinguir o papel da administração pública daquele do Governo.

\title{
2.1.2 Administração Pública e Reforma
}

Mello (2008, p. 65) afirma que não existe coincidência necessária entre interesse público e interesse do Estado, já que:

\begin{abstract}
os interesses públicos correspondem à dimensão pública dos interesses individuais, ou seja, que consistem no plexo dos interesses dos indivíduos enquanto partícipes da Sociedade (entificada juridicamente no Estado), nisto incluído o depósito intertemporal destes mesmos interesses.
\end{abstract}

Assim sendo, visando atender à busca contínua da sociedade em harmonizar os interesses público e estatal, de forma que o último sirva melhor ao primeiro, o Estado passa algumas vezes por reformas. Reformas aqui consideradas como aquelas que trazem "profundas mudanças institucionais e não apenas as mudanças habituais no organograma que cada novo governo geralmente realiza" (PEREIRA, 2009, p. 22).

Portanto, como Administração Pública e o Estado estão intrinsecamente ligados, a reforma e a evolução do Estado, implicam na reforma e evolução da Administração Pública enquanto macroestrutura a serviço do Estado (FERRAZ, 2008). Assim, cabe a ela se reformar continuamente para melhor executar as diretrizes estatais e governamentais na consecução dos interesses públicos apresentados pela sociedade.

A Administração Pública se apresenta, então, como uma organização; e, como qualquer organização, sofre constantes processos de adaptação com o passar do tempo para se ajustar às novas condições impostas pelo ambiente (BERGUE, 2007).

Ignorando a origem do Estado enquanto instituição humana, iniciada milhares de anos antes de Cristo com a fixação de povos nômades na Mesopotâmia, a construção do Estado Moderno vem sendo realizada por seus cidadãos através de um processo de progressiva democratização da sociedade civil e do próprio Estado desde o século XVI; quando nasce absoluto e centralizador, transformando-se em liberal no século XIX e se tornando democrático no século XX. Por sua vez, a Administração Pública nasce patrimonialista, transforma-se em burocrática no século XIX e, a partir do último quartel do século XX, inicia sua reforma gerencial - a segunda grande reforma administrativa do Estado capitalista (FERRAZ, 2008; PEREIRA, 2009). 
Admitindo a administração patrimonial, a administração burocrática e a administração gerencial como tipos ideais de administração do Estado, são identificadas duas reformas principais na organização do Estado: a reforma burocrática e a reforma gerencial também denominadas por Pereira (2009), respectivamente, de reforma do serviço público e reforma da gestão pública.

É necessário alertar, no entanto, que essa classificação se refere a tipos ideais. Mesmo se a proposição de modelos com atributos distintos sugere uma sucessão de estágios de desenvolvimento da Administração Pública, os elementos do modelo se traduzem em dimensões sobrepostas, algumas vezes observadas simultaneamente na realidade (BERGUE, 2007).

A Administração Pública patrimonialista alcança seu auge nos Estados absolutos modernos, apesar de ter se originado no sistema imperial chinês. Esse tipo de administração baseava-se no interesse direto do príncipe e da elite patrimonial aristocrática e burocrática, e no interesse indireto da aristocracia rural e da burguesia. Sua principal característica é a dificuldade em se distinguir entre o patrimônio privado do governante e o patrimônio público, atuando o aparelho do Estado como uma extensão do poder de seu dirigente. Sobrevive em sistemas democráticos imperfeitos, sob a forma de clientelismo ou fisiologismo (PEREIRA, 2009; MATIAS-PEREIRA, 2008).

Segundo Bergue (2007, p. 76), quanto à gestão de pessoas, identifica-se nesse modelo de Administração Pública a tendência ao nepotismo fundado nos seguintes valores: “a) crença de que laços familiares constituem a mais plena garantia de lealdade; b) oportunidade de distribuição de oportunidade profissional ou riqueza para a família; c) garantia de maior probabilidade de conivência com eventuais desvios". Conseqüentemente, os cargos públicos são percebidos como um privilégio a ser distribuído da maneira que se julgar conveniente, seja na forma de reconhecimento pessoal ou de moeda.

A Administração Pública burocrática nasce no século XIX, depois que: (a) os poderes do Estado, antes concentrados nas mãos do rei absoluto, são distribuídos entre o executivo, legislativo e judiciário; (b) o Estado assume, com o liberalismo econômico, um papel secundário na Economia em detrimento do mercado; e (c) a autoridade do Estado, antes onipotente, é reduzida com a afirmação dos direitos individuais expressos em normas jurídicas às quais também o Estado (bem como a Administração Pública) se subordina característica do Estado de Direito (FERRAZ, 2008).

Inicia-se, então, a reforma burocrática (ou reforma do serviço público). Visava combater a corrupção e o nepotismo patrimonialista, instaurando um serviço público 
profissional, procedimentos universais e legitimidade jurídica. Promoveu um importante avanço na Administração Pública e na proteção do patrimônio público com base nos princípios do desenvolvimento, da profissionalização, idéia de carreira pública, hierarquia funcional, impessoalidade e formalismo (PEREIRA, 2009; MATIAS-PEREIRA, 2008).

Esse modelo de administração caracteriza-se pelo controle rígido, preocupando-se fundamentalmente com o enquadramento jurídico do Estado. Por meio da submissão ao Direito entende-se possível limitar seu poder, combatendo o clientelismo, o fisiologismo, a corrupção e o nepotismo. Historicamente em conjunto com a reforma burocrática, surge e se consolida na Europa Continental um novo ramo do Direito para reger a Administração Pública e defender o patrimônio público contra a corrupção e o nepotismo: o Direito Administrativo (CHEVALLIER apud FERRAZ, 2008; PEREIRA, 2009).

Carvalho Filho (2006, p. 7) conceitua o Direito Administrativo como o "conjunto de normas e princípios que, visando sempre ao interesse público, regem as relações jurídicas entre as pessoas e órgãos do Estado e entre este e as coletividades a que devem servir". Para Nader (1996), afirma que esse direito não se confunde com a Ciência da Administração. Esta ciência estuda os modelos teóricos relativos à gestão dos interesses coletivos e ocupa-se com a política e a técnica da administração, além de oferecer importantes subsídios ao Direito Administrativo, que é tido como modelo concreto de administração da coisa pública, ao estabelecer a fórmula jurídica para a realização do serviço público.

Diversamente do sistema europeu-continental (statute law), em que a fonte principal é o direito legislado por herança do direito romano, o sistema anglo-americano (common law) - cujo Direito é "baseado no costume, no uso e nas decisões das Cortes de Justiça" (CRETELLA JÚNIOR apud DI PIETRO, 2004, p. 33) - implementou a reforma do serviço público distinguindo a esfera administrativa das esferas privada e política. Assim, EUA e Inglaterra superaram a administração patrimonial com base em princípios como o recrutamento de funcionários por mérito e a separação rigorosa entre a política e a administração, cabendo ao nível político a definição das políticas a desenvolver e à administração a sua implementação de acordo com as normas de boa gestão tendo em vista a eficácia (FERRAZ, 2008).

Com a segunda reforma da Administração Publica, ela passa de burocrática para gerencial com princípios, pressupostos e visão diferentes, porém não é um rompimento com os princípios anteriores, mas está apoiado neles. Permanece a busca por um serviço público profissional e racional, porém sua racionalidade depende mais de tomadas de decisão 
gerenciais do que da estrita observação de procedimentos burocráticos. Também se mantém a atenção ao controle, só que ele não se restringe aos procedimentos legais, exigindo que sejam assumidos objetivos, administrada a competição pela excelência e adotados vários esquemas de controle social (PEREIRA, 2009, p. 23).

Ainda que sejam identificadas virtudes na Administração Pública burocrática, ela se torna inadequada aos interesses da sociedade com a ampliação do papel do Estado em razão da intervenção estatal na ordem social para solucionar os problemas econômicos gerados pelo Estado liberal. Com os novos papéis sociais (educação, saúde, transporte, cultura, pesquisa científica, seguridade social e assistência social) e econômicos (estabilidade macroeconômica, regulação dos serviços públicos e das atividades monopolistas, fornecimento de infraestrutura pública, política industrial e de comércio exterior) assumidos pelo Estado democrático, as regras rígidas da administração burocrática passaram a se sobrepor aos interesses públicos (PEREIRA, 2009; MATIAS-PEREIRA, 2008).

A reforma gerencial (ou reforma da gestão pública) se inicia num contexto em que a sociedade passa a questionar fortemente o Estado e o modelo de Administração Pública burocrática em razão dos resultados insatisfatórios que estavam apresentando no atendimento às necessidades públicas.

Segundo Matias-Pereira (2008, p. 96-97), quatro fatores socioeconômicos contribuíram para agravar a crise do Estado a partir da década de 1970: (a) a crise econômica mundial gerada pelo fim do padrão de crescimento baseado no financiamento externo ou estatal iniciado no pós-Segunda Guerra Mundial; as conseqüentes (b) crise fiscal do Estado provocada e (c) crise de governabilidade, aliadas à perda de poder estatal para definir as políticas macroeconômicas com a (d) emergência da globalização e das inovações tecnológicas.

Portanto, o modelo gerencial da Administração Pública surge pela necessidade de redução do Estado e de modernização gerencial do setor público para elevar o nível de eficiência e eficácia do Estado democrático, estando relacionado com o desenvolvimento tecnológico e a globalização da economia mundial. Desloca-se, então, seu foco do controle rígido para o cidadão, para o desejo do cliente, buscando a melhoria da qualidade dos serviços oferecidos, a eficiência, a flexibilidade das regras, a melhoria do desempenho com controle dos resultados e a avaliação do processo (MATIAS-PEREIRA, 2008).

Com base em pesquisas realizadas sobre os movimentos de mudança no setor público da Grã-Bretanha e em extensa revisão da literatura sobre tais movimentos em 
diferentes países, Ferlie et al. (1999) propõem uma tipologia de quatro modelos ideais da Nova Administração Pública - considerada aqui como sinônimo de Administração Pública gerencial - que podem ser percebidos no setor público: (a) impulso para a eficiência, (b) downsizing e descentralização, (c) em busca da excelência, e (d) orientação para o serviço público.

Primeiro a surgir, o modelo Impulso para a Eficiência representa uma aproximação entre os serviços públicos e privados, propondo a transformação do setor público por meio da introdução rudimentar de noções de eficiência desenvolvidas pelo setor privado. Introduzindo uma mentalidade mais voltada para o mercado e para o cliente, esse modelo flexibiliza o regime jurídico dos agentes públicos ao utilizar formas alternativas de contrato de trabalho (emprego temporário, de tempo parcial etc.) e a substituição dos acordos de trabalho nacionais por acordos locais.

Para o paradigma Downsizing e Descentralização os principais aspectos referem-se: à ênfase nas organizações híbridas, misto de público e privado, com separação entre financiamento público e dotação do setor autônomo; à mudança da gestão hierárquica para a gestão por contrato; à criação, em âmbito local, de organizações com maior nível de autonomia. Busca-se maior flexibilidade, abandono do alto grau de padronização, descentralização da responsabilidade pela formulação da estratégia e do orçamento, aumento da terceirização, bem como a divisão dos quadros de pessoal entre um pequeno núcleo estratégico e uma grande periferia operacional. Destaca-se ainda a horizontalização da estrutura organizacional, com redução de pessoal, tanto nos escalões mais altos quanto na base das organizações.

Dentre esses tipos ideais, interessa mais ao presente estudo o Em Busca da Excelência, pois enfatiza a importância da cultura organizacional ao aplicar os princípios da escola de relações humanas da teoria administrativa no setor público. Foca no modo como as organizações gerenciam a mudança e a inovação, rejeitando a abordagem altamente racional do modelo Impulso para a Eficiência e ressaltando o papel que os valores, a cultura, os ritos e os símbolos têm na maneira como as pessoas verdadeiramente se comportam no trabalho.

Esse modelo se subdivide nas abordagens ascendente (bottom-up) e descendente (top-down). A ascendente trata de temas relacionados ao desenvolvimento e aprendizagem organizacionais e a formas de gestão baseadas no autodesenvolvimento e na participação, dando ênfase na gestão da cultura organizacional e na avaliação de desempenho com base em resultados. A segunda abordagem privilegia o papel da liderança na condução dos processos de mudança, além de debater sobre gerenciamento da mudança cultural, a utilização de 
formas carismáticas de liderança (em detrimento de formas transacionais), a ênfase em programas de treinamento e valorização da marca corporativa, o estabelecimento de uma missão, de uma estratégia explícita de comunicação, e a valorização da função gestão de pessoas como firme e estratégica.

Finalmente, o Orientação para o Serviço Público, padrão menos desenvolvido, propõe-se a reunir as tecnologias de gestão dos setores público e privado para delinear uma missão de serviço público diferente e assimilar práticas gerenciais bem-sucedidas do setor privado, revitalizando o papel dos administradores da Administração Pública. Caracteriza-se por uma grande ênfase na qualidade do serviço e na análise custo/benefício, baseada no propósito de alcançar a excelência dos serviços públicos, além de incluir o desenvolvimento do trabalho comunitário, a avaliação de demandas sociais e a garantia da participação popular na formulação de políticas e na avaliação dos serviços públicos.

Na qualidade de tipos ideais, esses modelos de Administração Pública gerencial não são excludentes. Guimarães (2000) os vê como parte de um continuum que vai da racionalidade economicista e burocrática do Impulso para a Eficiência à valorização da cidadania do Orientação para o Serviço Público. Esse autor também destaca a presença de dois pressupostos nos quatro modelos: (a) a prestação de serviços públicos deve ter como base a qualidade, a eficiência e a efetividade; e (b) as organizações públicas têm que passar por um processo de racionalização organizacional no qual o modelo de gestão, baseado na hierarquia, ceda lugar a um novo modelo fundamentado na flexibilidade. Um dos modelos capazes de racionalizar a Administração Pública é o paradigma da gestão por competências, que será estudado mais a frente.

Dentre as tentativas de eliminar ou reduzir a rigidez dos mecanismos de gestão de pessoas utilizados na administração burocrática, destacam-se as mudanças relacionadas ao recrutamento e à seleção. Nesse âmbito, a Administração Pública gerencial está centrada em

superar os mecanismos baseados estritamente em conhecimentos técnicos
especializados ou em méritos simplesmente formais, característicos dos processos
tradicionais da função pública. Falamos aqui tanto dos sistemas de acesso à condição
de funcionário público, próprios dos sistemas de carreira, quanto dos que se aplicam
ao acesso ao posto de trabalho; seja atuando nos mercados de trabalho exteriores à
administração, seja mediante a promoção interna. Em ambos os casos, as tendências
dominantes de mudança apontam para a introdução de modelos baseados em
competência (LONGO, 2007, p. 146).

Por fim, reconhecendo a relevância das pessoas que atuam em nome da Administração Pública na concretização do interesse público, conclui-se o presente tópico com o breve esclarecimento de Pereira (2009, p. 205) sobre a reforma da gestão pública em 
curso: “A reforma da gestão pública pretende criar novas instituições jurídicas e organizacionais que permitam transformar os burocratas profissionais em administradores públicos".

\subsubsection{Administração Pública Gerencial e Gestão por Competências}

Como foi apenas exposto, a Administração Pública passa por um período de reformas em seu modelo burocrático, baseado na hierarquia e no controle, em vista de um modelo gerencial, fundado na flexibilidade.

Nesse sentido, um dos novos modelos de gestão elaborados com vistas a tornar as organizações mais flexíveis e competitivas, em razão das mudanças da nova ordem econômica mundial imposta pela globalização, é a gestão por competências.

Guimarães (2000) identifica na literatura três correntes que tratam do modelo gestão por competências: (a) administração estratégica, (b) gestão de recursos humanos e (c) sociologia da educação e do trabalho.

A corrente da administração estratégica conta com Prahalad \& Hamel e Hill \& Jones como representantes e aborda o conceito de competência na gestão da organização como um todo, em seu nível macro, reconhecendo na gestão das competências essenciais a solução para os problemas organizacionais. Dividindo as competências organizacionais em básicas e essenciais, as primeiras correspondem àquelas que possibilitam o ingresso da organização no mercado, mas não garantem sua permanência; enquanto as competências essenciais compreendem um conjunto de conhecimentos, habilidades, tecnologias e sistemas físicos, gerenciais e de valores, dificilmente imitados pela concorrência, que geram valor distintivo percebido pelos clientes e que, dessa forma, conferem vantagem competitiva para a organização (GUIMARÃES, 2000; CARVALHO; PASSOS; SARAIVA, 2008).

Representada por Whiddett e Hollyforde, a corrente da gestão de recursos humanos, preconiza o uso do conceito de competência para integrar as atividades de gestão de pessoas, por intermédio de seu uso em processos de seleção, treinamento, avaliação e remuneração. $\mathrm{O}$ conceito de competência, então, corresponderia a: (a) as descrições das tarefas e resultados do trabalho, que permitam medir a habilidade do indivíduo em obter um desempenho compatível com os padrões requeridos pela empresa; (b) as prescrições dos comportamentos esperados dos indivíduos no ambiente de trabalho; ou (c) a combinação das condições anteriores. 
Partindo das chaves do aprendizado individual de Pestalozzi (tríplice atividade da cabeça, das mãos e do coração), Durand (apud Brandão, 2001) propõe um conceito de competência que envolve conhecimentos, habilidades e atitudes, englobando não só questões técnicas, mas também aspectos sociais e afetivos relacionados ao trabalho.

O conhecimento corresponde a diversas informações assimiladas e estruturadas pelo indivíduo e também a capacidade de receber informações e integrá-las dentro de um esquema preexistente, o pensamento e a visão estratégicos. Quanto à habilidade, essa se refere à capacidade de agir de acordo com objetivos ou processos predefinidos, com técnica e aptidão. Já a atitude refere-se a aspectos afetivos e sociais relacionados ao trabalho e à identidade do indivíduo com os valores da organização, contribuindo para que haja o seu comprometimento e motivação para alcançar os padrões de comportamento esperados e, assim, atingir resultados no trabalho com alta performance (GUIMARÃES, 2000).

Finalmente, a terceira corrente (sociologia da educação e do trabalho) foca nos principais impactos decorrentes da gestão por competências no sistema educacional e no mundo do trabalho, tendo Zarifian, Ropé \& Tanguy e Hirata. Discute os aspectos psicossociais desse modelo de gestão quando impacta nos programas educacionais, nos níveis de qualificação de mão-de-obra e emprego. Um desses aspectos é destacado por Zarifian, que destaca as consequiências da lógica da competência na essência das práticas de gestão de pessoas e nas bases e termos das relações profissionais e das negociações coletivas.

De acordo com Brandão e Guimarães (1999), citado por Guimarães (2000), para que uma organização utilize um modelo de gestão de pessoas baseado em competências é essencial que ela planeje, selecione, desenvolva e remunere seus recursos humanos focando as competências essenciais. É por meio da estratégia organizacional que a empresa identificará as competências necessárias para que seja concretizada a sua visão de futuro, isto é, as competências organizacionais. Essa visão estratégica da empresa orienta as políticas e ações para aproximar as competências atuais e as necessárias ao alcance dos objetivos organizacionais.

A seguir é apresentada uma figura que descreve as principais etapas do processo de gestão por competências. 
Figura 1: Principais etapas do processo de gestão por competências

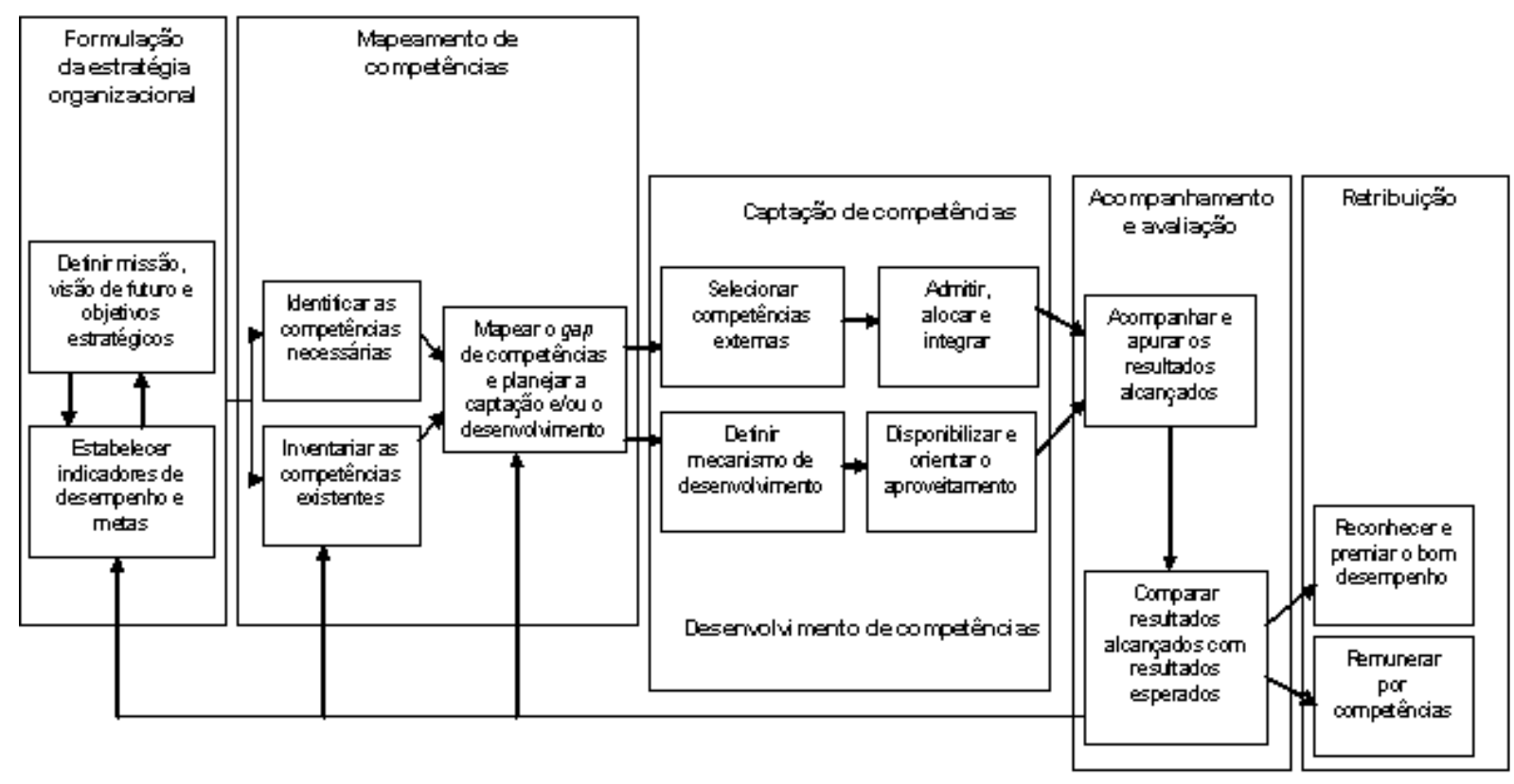

Fonte: Brandão, Hugo. P., Bahry, C arla. P., Getâo por competências: métodos e técnicas para

mapeamento de competências. Revista do Senviço Público, Brasília, 56 (2): 179 194. Abridun 2005

Reunindo - na Administração Pública gerencial - gestão da estratégia organizacional e gestão de pessoas no modelo baseado em competências, o planejamento estratégico é elaborado pelos órgãos governamentais estabelece as diretrizes que orientam todas as ações dos órgãos e entidades, inclusive o mapeamento das competências organizacionais e o planejamento da força de trabalho. Já a relação dos órgãos administrativos com o Governo pode ser comparada com aquela das unidades de uma empresa com sua alta direção, pois os níveis mais altos de direção são os definidores das diretrizes fundamentais a serem seguidas nos demais níveis organizacionais.

Portanto, fazendo uso do modelo de gestão por competências, a Administração Pública pode facilitar a implementação da reforma da gestão pública por meio de uma política consistente de gestão de pessoas flexível, inovadora e capaz de desenvolver uma visão integrada da atividade administrativa e das diretrizes gerais estabelecidas pelos órgãos governamentais no intuito de concretizar o interesse público.

\subsection{Seleção de Pessoas}

A comparação de pessoas para decidir quais são as mais adequadas e que mais se identificam com o trabalho a ser realizado caracteriza o processo de seleção de pessoas como a porta de entrada de novos trabalhadores em uma organização. Mesmo se tradicionalmente 
entendido por Taylor como a busca da pessoa certa para o lugar certo, esse processo ampliou seu foco ao buscar identificar as pessoas com o perfil mais adequado para desempenhar determinadas tarefas na organização, não apenas o profissional tecnicamente qualificado (FREITAS, 2004; CARVALHO; PASSOS; SARAIVA, 2008).

Considerando-se o ingresso de uma pessoa na organização como um macroprocesso, o processo de seleção sucede o processo de recrutamento. $\mathrm{O}$ recrutamento tem por objetivo localizar e atrair candidatos com o perfil que atenda às necessidades organizacionais presentes e futuras, tomando por base informações oriundas da análise organizacional, do mercado de trabalho e das competências importantes para que uma pessoa desempenhe satisfatoriamente suas atividades na organização. Em seguida, cabe à seleção escolher e classificar os candidatos recrutados que melhor atendam às necessidades da organização.

\subsubsection{Origem e evolução}

A preocupação em avaliar pessoas para identificar as mais preparadas para executar uma atividade, embrião das práticas de recrutamento e seleção, é tão antiga quanto a organização social dos povos, ainda que, por muito tempo, estivesse adstrita às forças militares. Atualmente, no entanto, o uso de "pistas" para tomar decisões e classificar pessoas se tornou muito comum em todas as culturas e em todos os países existem processos de selecionar pessoas para ocupações (CARVALHO; PASSOS; SARAIVA, 2008; SALGADO, 2000).

A preocupação em avaliar pessoas para identificar as mais preparadas para executar uma atividade, embrião das práticas de recrutamento e seleção, é tão antiga quanto a organização social dos povos, ainda que, por muito tempo, estivesse adstrita às forças militares. Atualmente, no entanto, o uso de "pistas" para tomar decisões e classificar pessoas se tornou muito comum em todas as culturas e em todos os países existem processos de selecionar pessoas para ocupações (CARVALHO; PASSOS; SARAIVA, 2008; SALGADO, 2000).

A seleção de pessoas como disciplina científica em Psicologia data apenas do início do século XX, quando começou o interesse pela seleção das melhores pessoas para o trabalho. Esse interesse estava relacionado com o desenvolvimento da Psicologia como ciência aplicada, com o desenvolvimento de métodos e procedimentos de avaliação e com o começo dos estudos sobre validade de critério. Acredita-se que Hugo Münstenberg foi o pai da seleção de pessoas científica. Ele, depois de realizar experimentos na Europa sobre seleção de 
pessoas, publicou o livro intitulado Psychologie und Wirtschaftsleben: Ein Beitrag zur angewabdten Experimental-Psychologie em 1912, traduzido em seguida para o inglês com o título de Psychology and Industrial Effeciency e publicado em Boston no ano de 1913.

No âmbito da Administração, Frederick W. Taylor, com a obra The Principle of Scientific Management publicada em 1911, passa a defender a possibilidade de se alcançar maior produtividade no trabalho a partir de estudos sobre a eficiência organizacional. Para isso, apresenta quatro princípios da administração científica, cujo segundo é a seleção científica do trabalhador. Esse princípio levaria a empresa a aumentar a sua produtividade e seus lucros, pois o empregado requerido seria aquele que desempenhasse a tarefa mais compatível com suas aptidões, passando o processo de seleção a definir com maior clareza quais os requisitos básicos do profissional almejado.

Essas duas ciências, no entanto, passaram a interagir mais a partir das conclusões de Elton Mayo sobre as experiências de Hawthorne, entre 1927 e 1932, que indicaram a interação social como fator de maior interferência na produção que a capacidade física dos operários e as condições físicas dos ambientes de trabalho. Consequientemente, a motivação e o comportamento humano passaram a ser mais considerados nos estudos sobre eficiência organizacional, abrindo um maior espaço para a Psicologia nesse âmbito.

Uma de suas maiores contribuições nos processos de seleção foi o uso de testes como instrumental de medição dos traços psicológicos julgados necessários ao bom desempenho no cargo. A Psicometria foi, então, reconhecida como uma das principais responsáveis por atribuir status científico às práticas de seleção.

Atualmente, contudo, com o acirramento da competitividade em um mercado global e a necessidade de constante sintonia com as inovações, a simples utilização otimizada de recursos - que caracteriza a eficiência - deixa de ser suficiente para a sobrevivência da organização. Como consequiência, o modelo burocrático dá lugar a um modelo de gestão mais flexível, mais focado no cliente (seja ele externo ou interno) e com revisão constante de processos em busca de melhorias contínuas. Com efeito, as mudanças nas relações de trabalho, nas competências essenciais das organizações e no perfil do profissional requerido estão provocando alterações nos objetivos, técnicas e aplicações dos processos de recrutamento e seleção (CARVALHO; PASSOS; SARAIVA, 2008).

Nessa conjuntura, as empresas entenderam que estavam sofrendo maior influência da personalidade e motivação de seus trabalhadores e passaram a buscar pessoas flexíveis e 
proativas, com comportamentos e atitudes adequados à sua cultura, missão, visão e aos seus objetivos, em detrimento de um profissional que apresentasse apenas qualificação técnica.

Com vistas a dar respostas às questões desse contexto, as discussões científicas sobre o processo de seleção têm tratado, principalmente, sobre a validade preditiva dos instrumentos de seleção e sobre a seleção por competências. Esses dois pontos serão aprofundados mais a frente. Faz-se necessário tratar antes sobre os instrumentos de seleção.

\subsubsection{Instrumentos de seleção}

Antes de abordar alguns dos principais instrumentos de seleção, cabe considerar a definição dada por Carvalho, Passos e Saraiva (2008, p. 78), na qual afirmam que "os instrumentos de seleção são aqueles que servem de auxílio à identificação das características básicas de cada candidato, para posterior associação com as competências exigidas no perfil estabelecido como referencial".

A seleção de candidatos não deve ser realizada somente por meio de avaliação da experiência e do conhecimento do cargo a ser ocupado, é imprescindível conhecer, por exemplo, aspectos relacionados à personalidade do candidato, a fim de verificar se a contratação será favorável para ambos - empresa e empregado. Além disso, a utilização de várias técnicas complementares pode contribuir para reduzir a probabilidade de erro na escolha do candidato (LIMONGI-FRANÇA; ARELLANO, 2002).

Em geral, os instrumentos de seleção têm diversas classificações. Por exemplo, esses autores apresentam cinco técnicas para realizar a seleção de pessoal: entrevistas, provas de conhecimento, testes psicológicos, técnicas vivenciais e avaliação de saúde. Já Carvalho, Passos e Saraiva (2008) apontam como alguns exemplos de instrumento de seleção os testes psicológicos, os testes de conhecimento, os instrumentos de avaliação de perfil, as dinâmicas de grupo e as entrevistas de grupo, que correspondem, em sua maioria, às técnicas apresentadas por Limongi-França e Arellano (2002).

Bohlander, Snell e Shermam (2005) classificam os testes de admissão, de forma diferenciada, em medidas da aptidão (medem a capacidade de uma pessoa para aprender ou adquirir habilidades) ou da realização (medem o que uma pessoa sabe ou pode fazer naquele momento).

Os primeiros instrumentos abordados aqui são os diferentes tipos de testes. Segundo Faissal et al (2005, p. 108), "a utilização de testes em processos de seleção se baseia no valor 
de predição dos testes, ou seja, na suposição de que há uma estreita correspondência entre o desempenho do candidato nos testes e seu desempenho futuro no trabalho."

Os testes psicológicos possibilitam medir ou avaliar qualquer atributo, como por exemplo, aptidão, atitudes, interesses, estabilidade emocional e também características de personalidade, como afirma Santos citado por Limongi-França e Arellano (2002). Esses testes são instrumentos padronizados que objetivam revelar o comportamento humano por meio das situações propostas, que estimulam determinado comportamento do candidato.

Os autores Carvalho, Passos e Saraiva (2008) acrescentam outra característica desses testes: avaliar ou identificar determinadas habilidades e raciocínios.

Os testes psicológicos apresentam-se no formato objetivo ou projetivo e dividem-se em psicométricos e de personalidade. Segundo Limongi-França e Arellano (2002, p. 69-70), os testes psicométricos medem as aptidões individuais, por meio de teste de inteligência, por exemplo, "determinando um índice comparado com escores ponderados e validados anteriormente"; e os testes de personalidade "identificam traços de personalidade, aspectos motivacionais, interesses e distúrbios", que afetam a vida do indivíduo e podem interferir em suas atividades profissionais. Faissal et al (2005, p. 108) mostram que os testes de inteligência visam avaliar o desenvolvimento intelectual geral por meio de diversas tarefas que englobem as funções intelectuais importantes.

Quanto aos testes de conhecimento, de acordo com Carvalho, Passos e Saraiva (2008, p. 80), esses testes "pretendem medir o conhecimento do candidato relativamente a aspectos gerais de cultura ou a competência requerida para uma boa atuação na área em que poderá vir a trabalhar, caso admitido". Os testes de conhecimento são bastante utilizados em processos seletivos, especialmente em concursos públicos, e podem ser gerais ou específicos. Faissal et al (2005) classificam-nos em: objetivos, discursivos, situacionais, escritos, práticos e orais.

Alguns exemplos de testes de conhecimento gerais são os de redação, português e matemática, realizados nos diversos níveis de complexidade observando-se a escolaridade exigida para o cargo. De acordo com Limongi-França e Arellano (2002, p.69), esses testes "têm baixa correlação com o desempenho profissional imediato, porém servem para entender melhor o universo do candidato e sua atitude pessoal-profissional". Os testes específicos, como de matemática financeira, mecânica e idiomas, têm o objetivo de avaliar os 
conhecimentos profissionais que o candidato possui, sendo necessários para um bom desempenho das atividades pertinentes ao cargo pretendido na seleção.

Especificamente sobre os testes situacionais, Faissal et al (2005, p. 111) afirmam que, atualmente, têm sido bastante utilizados e "são atividades estruturadas que colocam o candidato diante de uma situação típica de seu dia-a-dia de trabalho, visando avaliar sua capacidade de percepção, de análise e de solução de um problema concreto".

Limongi-França e Arellano (2002, p. 70) classificam-nos como técnicas vivenciais que "exigem respostas a situações de forma que os candidatos interajam e participem ativamente delas”. Para Carvalho, Passos e Saraiva (2008, p. 81), os testes situacionais são realizados a fim de "medir habilidades específicas que o candidato deverá possuir para obter um desempenho satisfatório no cargo em aberto".

Em geral, os testes situacionais são utilizados quando a vaga, objeto da seleção, apresenta várias situações diferenciadas e requer que o profissional tenha flexibilidade e conhecimento para responder adequadamente a elas. Além disso, como o controle da situação pelo candidato é reduzido, os resultados podem ser mais visíveis e espontâneos, porque as atividades envolvem, na prática, atuação e simulações de uma ou mais circunstâncias profissional, que pode ser enfrentada pelo candidato no desempenho das atividades inerentes ao cargo pretendido.

Uma forma de realizar esses testes é por meio de estudos de caso, dramatizações ou simulações. Quanto aos "estudos de caso, assim como as dramatizações, trazem para os candidatos situações fictícias, com base em dados reais e que exigem uma capacidade de pensar e agir em linha com o relatado ou descrito", reproduzindo, assim, o cotidiano. "Por meio desse instrumento é possível observar o grau de percepção do candidato, sua capacidade de organizar e planejar, de tomar decisões, de definir prioridades e de agir de forma proativa" (CARVALHO; PASSOS; SARAIVA, 2008, p. 81).

De acordo com Bohlander, Snell e Shermam (2005), empresas interessadas em adotar a seleção baseada na competência, isto é, com foco na observação de comportamentos que, de forma concreta, diferenciam os melhores candidatos, usam os exames práticos que são "elaborados a partir de uma relação cuidadosamente desenvolvida das principais funções do cargo". Em outras palavras, usam situações do cotidiano de trabalho para avaliar o potencial dos funcionários 'em ação'. Dentro dessas provas práticas, enquadram-se, segundo esses autores, o teste situacional para gerentes. 
De forma geral, a principal vantagem dos diversos testes (de conhecimento, de aptidão, de personalidade) é a objetividade atribuída a eles, pois apresentam estrutura, aplicação e avaliação padronizadas, utilizando critérios de avaliação definidos previamente, com base em dados empíricos e iguais para qualquer avaliador. Conseqüentemente, evita-se julgamento subjetivo do selecionador durante a avaliação, cabendo ressaltar que a subjetividade é inerente a qualquer pessoa. Outra vantagem dos testes é a possibilidade de aplicação coletiva, o que implica em tempo reduzido (FAISSAL et al, 2005).

Tratando-se das desvantagens dos testes, esses autores apontam como a principal, de forma particular no Brasil, o reduzido número de estudos e pesquisas adaptados à realidade e características da população local. Dentre outras desvantagens, encontram-se a possibilidade de manipulação das respostas e o uso massificado dos testes - que se tornaram públicos.

Concluindo a descrição sobre os testes de seleção, Faissal et al ressaltam que:

(...) nenhum teste, por maior que sejam as evidências empíricas sobre a sua validade e a sua precisão, deve ser utilizado como instrumento único e isolado de avaliação. Os testes devem sempre ser coadjuvantes do processo, atuando como mais uma entre as diversas fontes de dados à disposição do selecionador. (FAISSAL et al, 2005, p. 116-117)

Outro instrumento de seleção muito utilizado atualmente são os desenvolvidos para verificar o perfil dos candidatos. Eles identificam e associam certas características e comportamentos dos candidatos, muitas vezes fundamentais para o exercício do cargo em questão. Uma de suas vantagens é não "ameaçar" quem os realiza, já que não existem respostas certas ou erradas. São elaborados comumente no formato de formulário que, comparando fatores previamente estabelecidos com as respostas do candidato, apresentam um perfil psicológico do respondente (CARVALHO; PASSOS; SARAIVA, 2008).

A dinâmica de grupo é outro tipo de instrumento de seleção por meio do qual, segundo Faissal et al (2005), é proposto a um grupo de candidatos um conjunto de atividades, como jogos, simulações, estudos de caso e debates. Para Carvalho, Passos e Saraiva (2008), elas são utilizadas para estudar e avaliar a natureza do grupo e a dinâmica que rege seu desenvolvimento, além das relações entre: indivíduo e grupo; grupo e grupo; grupos e instituições. Esse instrumento de seleção, além de permitir a avaliação das habilidades interpessoais e atitudes, fornece muitas informações sobre o candidato que possibilitam observar a inter-relação do seu perfil com o perfil de competências definido para o cargo, com base na observação direta do comportamento dos candidatos pelo avaliador. 
Considerando que a observação (subjetiva) é o meio pelo qual o avaliador coletará os dados para a avaliação dos candidatos durante a realização da dinâmica de grupo, é essencial atentar para os dois requisitos citados por Faissal et al (2005, p. 118) para que a validade desse instrumento seja garantida: as tarefas propostas aos candidatos devem ser "efetivamente capazes de expressar a competência que se pretende observar"; e deve-se "criar condições que favoreçam a objetividade da observação". Dessa forma, procura-se evitar a má utilização desse instrumento seja pela ausência de compreensão da técnica ou de preparo de alguns profissionais.

Considerando que a observação exige um caráter mais cientifico, para que uma dinâmica de grupo seja plenamente validada ela deve ser objetiva e sistemática; esta última "requer do observador a capacidade de descrever e de registrar o comportamento observado" (FAISSAL et al, 2005, p. 120).

Como pode ser observada, a dinâmica de grupo é um processo complexo, que requer também uma interação boa do grupo a ser avaliado, certa quantidade de integrantes por grupo e de observadores, além de ser influenciada pelo estado psicológico de quem recebe o estímulo, pois envolve as experiências anteriores, motivação e expectativas. Esse instrumento requer, ainda, habilidades muito específicas dos avaliadores. Eles devem ser capazes, por exemplo, de relatar de forma objetiva o que ocorreu durante o processo, ou seja, as ações, evitando a utilização de termos subjetivos ou interpretações das intenções e finalidades dos candidatos.

Se, depois da realização de uma dinâmica de grupo, da forma mais adequada e validada possível, ainda persistirem dúvidas sobre algum aspecto do perfil de competências do candidato, Faissal et al (2005) afirmam que a entrevista de seleção é a técnica adequada para esclarecer esses aspectos.

É consenso entre diversos autores que o instrumento mais importante na coleta de informações e na tomada de decisão na seleção é a entrevista, assumindo papel central nesse processo. Algum tipo de entrevista está presente praticamente em toda seleção, no entnato, é aconselhado por muito autores que nenhum instrumento deve ser utilizado isoladamende, nem mesmo a entrevista.

Como declaram Faissal et al, a entrevista:

Consiste na proposição de perguntas aos candidatos, tendo como objetivo avaliar o domínio de determinadas competências relacionadas ao perfil profissional, levantar informações complementares sobre competências que não foram vistas por meio de 
outras técnicas, investigar mais profundamente aspectos de uma competência que não tenham sido suficientemente explorados e esclarecer fatos, impressões, confirmar ou rejeitar hipóteses que surgiram ao longo do processo seletivo. (FAISSAL et al, 2005, p. 125).

Ainda que utilizada com muita freqüência, a constituição da entrevista como instrumento de seleção efetivo e eficaz depende de conhecimento, habilidade e tato, em razão da alta dosagem de subjetividade e imprecisão que apresenta (CARVALHO; PASSOS; SARAIVA, 2008).

Considerando a grande subjetividade da entrevista, para que esse instrumento tão essencial seja validado e evite inclinações pessoais, ele deve ser conduzido por profissionais experientes e capazes de identificar os fatores de ordem pessoal que podem interferir no processo, como preconceitos, antipatia, atração, esteriótipos etc.; esses profissionais devem considerar as expectativas da área detentora do cargo; garantir que o mesmo candidato seja avaliado por vários entrevistadores (membros de uma equipe de trabalho ou outros indivíduos na empresa), apesar de, dependendo do tipo de seleção, poder ser entrevistado por uma pessoa (FAISSAL et al, 2005; LIMONGI-FRANÇA; ARELLANO, 2002).

A entrevista individual é o método em que o candidato se apresenta pessoalmente ao profissional de seleção, que realiza perguntas, anota as respostas e avalia as competências apresentadas com base nas informações obtidas. Pode-se afirmar, de acordo com Bohlander, Snell e Shermam (2005), que a estrutura da entrevista e o treinamento dos entrevistadores realmente influenciam o sucesso do processo de contratação.

Faissal et al (2005, p. 126) classificam as entrevistas "quanto ao grau de estruturação, ao tipo de informação que se deseja obter e ao tipo de pergunta utilizada".

Em relação ao grau de estruturação, as entrevistas podem ser estruturadas e nãoestruturadas. Nas entrevistas estruturadas, o entrevistador estipula a direção que a entrevista terá ao fazer perguntas padronizadas e planejadas, baseadas na análise de cargo, e o candidato responde somente a essas questões. As suas principais vantagens, afirma Faissal et al (2005), são a possíbilidade de englobar todas as informações necessárias para analisar se o candidato possui o perfil desejado e o fato das informações obtidas serem uniformes. Para Limongi-França e Arellano (2002) as entrevistas estruturadas fornecem uma base mais consistente de avaliação e contribuem para uma tomada de decisão mais segura e com possibilidade reduzida de haver acusações de discriminação injusta.

Nas entrevistas não-estruturadas, são poucas as perguntas planejadas, sendo outras formuladas durante o diálogo, e o candidato desempenha papel mais amplo na determinação 
do curso da discussão. De acordo com Bohlander, Snell e Shermam (2005), nas entrevistas não estruturadas ou não-dirigidas, como as denominam, o candidato tem liberdade ao dar suas respostas e direcionar a entrevista, pois o entrevistador evita interrompê-lo e influenciar os seus comentários.

Essa liberdade dada ao candidato é positiva e valiosa por permitir que ele dê informações, demosntre atitudes e sentimentos que poderiam ser ocultados por perguntas mais estruturadas. No entanto, esse tipo de entrevista é menos objetivo, tendo em vista que o candidato determina o curso da entrevista e, dessa forma, poucas informações coletadas permitem aos entrevistadores chegar a um acordo entre si. Dessa forma, há tendênia a ter pouca confiabilidade e validade (BOHLANDER; SNELL; SHERMAM, 2005).

Outra classificação das entrevistas é pelo tipo de informação que se deseja obter, podendo ser técnicas ou psicológicas. As entrevistas técnicas tem um caráter decisivo e, como sugere Faissal et al (2005), deve ser realizada no final do processo, pois geralmente são conduzidas pelo profissional detentor da vaga e objetivam coletar informações no que diz respeito ao conhecimento técnico do candidato, sua experiência profissional e habilidades técnicas.

Por outro lado, as entrevistas psicológicas visam obter informações sobre aspectos da personalidade do candidato, bem como de sua vida pessoal passada e expectativas para o futuro, para que seja possível elaborar um perfil psicológico a fim de verificar a sua adequação ao perfil de competências do cargo objeto da seleção. Devido à dificuldade de aprofundar os dados coletados - o que não ocorre com as entrevistas técnicas - pelo pouco tempo para realizar os processos seletivos e pela exigência de serem psicólogos a conduzirem as entrevistas psicológicas, estas estão sendo usadas com pouca freqüência (FAISSAL et al, 2005).

Esses autores ressaltam que se tiverem sido utilizados testes psicológicos durante o processo de seleção, torna-se necessária a realização da entrevista psicológica, conduzida por profissional da área, para que possa ser efetuada a correlação das informações e a tomada de decisão.

Limongi-França e Arellano (2002) descrevem alguns aspectos importantes que devem ser abordados durante as entrevistas, com foco no tipo de informação a ser obtida: desenvolvimento de carreira (formação profissional, experiências anteriores, insatisfações, planos e ambições de carreira); relacionamento profissional com colegas, subordinados e 
chefias nos empregos anteriores; ambiente familiar (estrutura familiar e responsabilidades econômicas); interesses pessoais (hobbies); relacionameto social (associação ou religião); perspectivas futuras (planejamento de vida e autogestão de carreira).

Quanto ao tipo de pergunta utilizada nas entrevistas, elas são tradicionais, situacionais ou comportamentais. Nas tradicionais, o entrevistador faz perguntas gerais e abertas para que o candidato fale sobre o que foi sugerido, oferecendo informações para que seja efetuada a avaliação do seu perfil com as competências requeridas. No caso das entrevistas situacionais, consideradas uma variação da anterior, são feitas perguntas abertas e direcionadas às características específicas do trabalho pertinente ao cargo a ser ocupado pelo candidato selecionado. É apresentado ao candidato um fato hipotético e ele deve responder que reação teria. Um aspecto negativo desse tipo de entrevista é que, em geral, as perguntas levam o candidato a responder de forma ideal, o que muitas vezes não corresponde à realidade (FAISSAL et al, 2005).

Em relação às entrevistas comportamentais, o conceito apresentado por Reis (2003), citado por Faissal et al, mostra que:

exemplos comportamentais (fatos específicos da experiência passada) são a melhor maneira de prever o comportamento futuro de um candidato. Ao invés de fazer perguntas ao candidato que o remetem a situações hipotéticas, condicionais, o entrevistador formula a pergunta solicitando ao candidato que descreva uma situação concreta, que ilustre a competência que se pretende analisar. (REIS apud FAISSAL et al, 2005, p. 116-117).

Nesse tipo de entrevista as perguntas são abertas e específicas, com foco nas competências necessárias para o cargo, visando obter descrições de exemplos comportamentais ocorridos na vida do candidato que indiquem evidências de uma competência.

Uma vantagem desse tipo de entrevista são as maiores chances de conseguir uma resposta mais realista, com informações mais precisas sobre as competências do candidato. Assim, ao analisar os dados obtidos, o avaliador terá um indicador mais seguro para contribuir em sua tomada de decisão. Cabe ressaltar que o comportamento futuro do candidato pode ser diferente de seus comportamentos anteriores, devido à característica humana de realizar mudanças pessoais, não sendo, assim, um indicador absoluto e infalível.

Faissal et al (2005) ressaltam que, apesar do caráter de interação social fornecido pela entrevista, ela é mais bem aproveitada à medida que for utilizada como um instrumento de síntese de todos os resultados. 
Milkovich e Boudreau (2008, p. 319) comentam que ao selecionar candidatos para funções de chefia é quase óbvio que seja realizada simulações de situações reais desse papel. Além dessa avaliação, os candidatos seriam entrevistados e uma equipe de avaliadores observaria todas as atividades para discutir e realizar considerações que levariam a uma decisão final. Esses autores denominam esse tipo de procedimento de seleção de Centro de Avaliação, que "não é um lugar, mas um conjunto de atividades de seleção julgadas por um grupo de assessores".

Os centros de avaliação é uma das várias maneiras de estimar o potencial futuro dos candidatos. Eles combinam as avaliações de conhecimento, desenvolvidos com base na análise da função que identifica os fatos ou regras essenciais que precisam ser conhecidos por quem vai desempenhá-la, e as simulações, reproduções dos comportamentos cotidianos do trabalho (Milkovich e Boudreau, 2008).

Segundo Peña (2007), nos centros de avaliação um grupo de especialistas observa e avalia o comportamento dos candidatos enquanto eles realizam diversas atividades definidas previamente e que correspondem àquelas do cargo que visam ocupar. Apesar de ser um instrumento muito efetivo e participativo, é oneroso em tempo e em recursos financeiros, sendo aplicado somente por algumas organizações para selecionar pessoas para cargos estratégicos. Mesmo os centro de avaliação sendo mais onerosos que procedimentos de seleção mais simples, podem valer o investimento se usados para várias decisões de contratação de pessoal, ainda que não exista uma confirmação de que eles sejam instrumentos mais eficazes do que alternativas mais baratas.

Por fim, Faissal et al (2005) ressaltam que por meio da aplicação dos diversos instrumentos de seleção, a empresa obterá as competências de que necessita para manter-se competitiva. 


\title{
2.2.3 Seleção por competências
}

Como visto anteriormente, um dos novos modelos de gestão elaborados com vistas a tornar as organizações mais flexíveis e competitivas, em razão das mudanças da nova ordem econômica mundial imposta pela globalização, é a gestão por competências.

Especificamente no âmbito da seleção, esse novo modelo de gestão admite uma nova forma de conduzir o ingresso de uma pessoa na organização: a seleção por competências. Ainda que no modelo mais tradicional de recrutamento e seleção seja definido um perfil de competências necessárias para o desempenho das atividades que o candidato executará, essa nova forma se destaca pela necessidade de alinhamento entre as competências funcionais e organizacionais:

\begin{abstract}
A especificidade da seleção por competências reside nos elementos que serão utilizados para elaboração do perfil de competências. Nos modelos tradicionais de seleção, o ponto de partida para o perfil era a descrição do cargo. A partir dessa descrição, deduziam-se as competências necessárias.

$\mathrm{Na}$ seleção por competências, apesar dos cargos continuarem sendo a unidade de análise, deverá ser mapeado o conjunto de saberes que seus respectivos ocupantes devem ter - o que precisam saber, saber fazer, saber ser -, levando-se em conta que tais saberes deverão dar suporte às competências organizacionais para que elas possam concretizar-se. Por exemplo, se um empreendimento requer como competência organizacional a capacidade de inovação contínua, além das competências requeridas pelas atividades específicas de cada cargo, devemos considerar que seus ocupantes deverão ser criativos de maneira que, em seus processos de trabalho, produzam as inovações que sustentarão a vantagem competitiva da organização. (CARVALHO; PASSOS; SARAIVA, 2008, p. 49-50).
\end{abstract}

Portanto, para a definição do perfil de competências funcionais necessárias aos candidatos que se apresentam para a seleção, é indispensável a atividade estratégica de mapeamento das competências organizacionais realizada pelos principais executivos da organização, permitindo seu alinhamento à gestão de pessoas e ao processo de seleção por competências.

Milkovich e Boudreau afirmam que é essencial:

compreender a ligação entre os objetivos da organização e a estratégia de seleção externa. Essa estratégia deve partir diretamente da análise das metas organizacionais, que indicará papéis e contribuições necessários para o trabalho, que determinarão as características a serem buscadas nos candidatos que, finalmente, guiarão as escolhas dos métodos de seleção e da avaliação de sua eficácia. (MILKOVICH; BOUDREAU, 2008, p. 210-211)

Ressalta-se que as competências organizacionais, juntamente com outros dados, fornecem informações sobre um cargo que contribuirão para a especificação das competências funcionais requeridas para que o ocupante possa desempenhá-lo com sucesso. 
Outro ponto importante é a definição conceitual das competências funcionais, por meio de indicadores concretos e observáveis das competências que pretende avaliar, para que todos os envolvidos no processo de seleção tenham a mesma compreensão do significado de cada competência estabelecida. Carvalho, Passos e Saraiva (2008, p. 53), resumem essas considerações conceituando seleção por competências como "o processo de escolha de candidatos baseado nas competências organizacionais e na definição de indicadores de competências funcionais".

Peña (2007) afirma que na seleção por competências também são utilizados os centro de avaliação. Ployhart (2006) relata que conforme estudos realizados sobre a validade, os construtos e os exercícios desenvolvidos pelos centros de avaliação, constatou-se que quando esse é utilizado como instrumento na seleção por competências, mensura dez competências dentre as quais se destacam: habilidades interpessoais / sensibilidade social, comunicação, motivação, persuasão / influência, organização / planejamento e solução de problemas.

Considerando as características da seleção por competências e seu diferencial, já apresentado neste tópico, cabe ressaltar que alguns instrumentos de seleção podem ser eficazes na decisão pelo candidato que possua o perfil de competências esperado - se for observado alguns aspectos relacionados às competências.

Por exemplo, a fim de evitar a subjetividade da avaliação por meio da dinâmica de grupo, gerada pelo ato de observar, Faissal et al (2005), citando Bueno (1995), ressaltam a importância de discutir, de forma detalhada, o conceito de cada competência a ser avaliada, definindo-as através de ações observáveis e descritíveis. Esse tipo de definição é denominada por Green (1999), citado por Faissal et al (2005, p. 119), como “definição operacional, que utiliza a linguagem comportamental, para descrever aquilo que "você pode ver e ouvir vendo sendo feito"'. Cabe ressaltar que a definição operacional das competências é proposta, além de fator necessário para a observação, mas como critério de objetividade para as dinâmicas de grupo, "preservando a avaliação dos seus critérios individuais, particulares, circunscritos à sua objetividade, embora não seja possível eliminá-la”.

\subsection{Concurso Público}

Concluídas as breves apresentações sobre como é abordada em textos acadêmicos a relação da Administração Pública e do processo de seleção de pessoas com o modelo de gestão por competências, inicia-se a apresentação do concurso público como forma de seleção de pessoas para a Administração Pública. 
Desde a Antiguidade, os entes estatais vêm utilizando diversas formas de selecionar pessoas para ocupar os cargos públicos: sorteio, compra e venda, sucessão hereditária, arrendamento, livre nomeação absoluta, livre nomeação relativa, eleição e concurso (CRETELLA JÚNIOR apud MAIA; QUEIROZ, 2007).

A experiência mais remota de concurso que se tem notícia é o sistema chinês de exames, iniciado aproximadamente no século IV, na China pós-feudalismo, governada por uma classe de profissionais que possuía, cada um, seu certificado de mérito no concurso. Os exames foram originalmente criados para testar os conhecimentos dos candidatos a um cargo estatal sobre os clássicos de Confúcio e sua capacidade de pensar à maneira de Confúcio. Aplicados em forma de exame em massa, com a tensão sendo multiplicada pela importância do cargo, os testes tinham como objeto textos complicados e poemas sobre os textos clássicos, além de problemas contemporâneos da filosofia e do governo. Mesmo sendo possível comprar cargos, o alto status era quase sempre associado a notas altas (WALZER, 2003).

No Estado Moderno, o concurso público desponta no contexto da reforma do serviço público para combater o nepotismo e o clientelismo, visando que os cargos públicos fossem ocupados por pessoas selecionadas com base no mérito.

Surge, então, o regime do concurso ou sistema de mérito (merit system) para se opor ao ingresso nos cargos públicos em razão do prestígio de políticos, de parentes ou de amigos, característico do sistema do pistolão, sistema do apadrinhamento ou sistema dos despojos (patronage system ou spoils system) (SIQUEIRA, 1950). O sistema de mérito, conforme Kasznar (1996), tem a notável vantagem de avaliar as pessoas a partir de seus objetivos e específicos méritos próprios, em vez de utilizar meios subjetivos como sentimentos pessoais, relacionamentos e outros métodos não-profissionais.

Considerando questões de ordem social (democratização do Estado) e técnica (administração eficiente), o concurso público torna os cargos públicos acessíveis a todos os cidadãos e viabiliza o ingresso dos mais qualificados na Administração Pública. Além disso, mesmo sendo uma instituição humana sujeita a toda sorte de vícios, o concurso público é considerado o único meio de seleção de servidores que condiz com o sistema de mérito, já que se mostra superior: (a) ao sorteio, não constituindo sistema meramente aleatório; (b) ao arrendamento, à compra e venda e à herança, não tratando o cargo público como objeto mercantil ou de sucessão hereditária; e (c) à livre nomeação e à eleição, não adotando como critério de escolha do servidor público a valoração puramente discricionária ou de natureza eminentemente político-econômica (SIQUEIRA, 1950; MAIA; QUEIROZ, 2007). 
O concurso público compreende a atração do maior número de candidatos qualificados (recrutamento amplo) e a escolha (seleção rígida), com base em critérios tecnicamente estabelecidos, dos que apresentarem os mais elevados graus de capacidade, com relação aos requisitos mínimos fixados para o exercício eficiente dos cargos a serem providos (SIQUEIRA, 1950).

Reúne, portanto, as duas fases iniciais do suprimento de recursos humanos para a Administração Pública, denominado processo admissional; dividindo-se, este último, em quatro atividades (fases) que também podem ser detalhadas segundo processos específicos: recrutamento, seleção, admissão e registro (BERGUE, 2007).

Genericamente esclarecidos os processos do concurso público, cabe destacar que nem todas as pessoas que desenvolvem suas atividades laborais na Administração Pública são selecionadas por meio do concurso público, dentre diversos fatores, em razão da reforma da gestão pública ter descentralizado a concretização do interesse público. Para se definir quais as pessoas que prestam serviço para o Estado se condicionam ao concurso público, faz-se necessário identificar como seu ordenamento jurídico organiza o exercício das funções públicas por pessoas físicas que executam e controlam o serviço público. Antes disso, entretanto, algumas definições serão apresentadas.

O Estado, para se manifestar e exercer suas funções públicas, depende de pessoas físicas; não sendo possível conceber a Administração Pública sem a presença de seu elemento físico, os agentes, que expressam a vontade estatal. Assim, todo aquele que, a qualquer título, executa uma função pública como preposto do Estado é considerado um agente público (CARVALHO FILHO, 2006).

Ainda que existam diversas tipologias, Mello (2008) classifica os agentes públicos em (a) agentes políticos, (b) servidores estatais e (c) particulares em colaboração com a Administração. Os agentes políticos se diferenciam dos demais por manterem vínculo político com o Estado, exercendo a função política no comando dos órgãos governamentais. A terceira categoria de agentes é composta por pessoas que, mesmo não perdendo sua qualidade de particulares, exercem função pública, ainda que eventualmente. Já os servidores estatais se distinguem dos demais pela relação de trabalho de natureza profissional e caráter não eventual sob vínculo de dependência que mantém com a Administração Pública.

Os últimos se ocupam da função administrativa em sentido estrito no controle/execução do serviço público, podendo ser subdivididos em: (i) servidores públicos, 
titulares de cargos públicos e sujeitos ao regime jurídico estatutário; (ii) empregados públicos, ocupantes de empregos públicos e regidos pela Consolidação das Leis do Trabalho (CLT); e (iii) servidores temporários, contratados por tempo determinado para atender a necessidade temporária de excepcional interesse público. Segundo o grau de segurança da manutenção do vínculo com a Administração Pública, os cargos ocupados pelos servidores públicos são classificados em vitalícios, efetivos e comissionados (ou de provimento em comissão), detentores, respectivamente, de vitaliciedade, estabilidade e provisoriedade (MELO, 2006).

Esclarecidos esses conceitos, identifica-se no sistema constitucional brasileiro a flexibilização da obrigatoriedade do concurso público na seleção de pessoas para o exercício da função administrativa estrita no controle/execução do serviço público em caráter temporário ou provisório (servidor temporário e servidor público comissionado); exigindo-o, em contrapartida, para o ingresso em empregos públicos e cargos públicos vitalícios ou efetivos.

Dessa forma, os cargos e empregos públicos vagos que necessitam de imediato provimento caracterizam-se como objeto material do concurso público; enquanto seu objeto jurídico (efeito jurídico imediato) corresponde ao preenchimento desses lugares vagos na estrutura estatal por pessoas previamente classificadas e selecionadas por intermédio de realização de provas ou provas e títulos, atendendo-se, rigorosamente, à ordem de classificação dos candidatos, fazendo nascer um vínculo jurídico de natureza funcional (cargo público) ou trabalhista (emprego público) entre o cidadão e a Administração Pública (MAIA; QUEIROZ, 2007).

Mesmo se o concurso público é marcado por regras e princípios específicos, ele se subordina ao regime jurídico do Direito Administrativo na medida em que compreende uma sucessão ordenada de atos administrativos visando a um interesse público específico: o recrutamento e a seleção de profissionais competentes e adequados à prestação de serviços a sociedade no exercício de cargos ou empregos públicos.

$\mathrm{Na}$ qualidade de processo administrativo, verifica-se no concurso público seu atributo de atividade administrativa na medida em que é uma função ou atividade-fim que se subordina à finalidade expressa nas normas constitucionais e legais. Entendida no sentido negativo,

a atividade administrativa encontra um limite formalmente insuperável na lei, a qual pode estabelecer proibições a determinadas atividades, tanto no que concerne às finalidades a alcançar como no que se refere aos meios e formas a seguir. Já no sentido positivo, tem-se que a lei pode vincular positivamente a atividade 
administrativa a determinadas finalidades ou a certos meios ou formas, cabendo à Administração realizar aquilo que a lei permite (ALESSI apud COELHO, 2004, p. 65).

Dessa maneira, com a finalidade de assegurar a escolha impessoal de profissionais competentes e adequados para a prestação de serviços à população, a Administração Pública deve conciliar princípios como legalidade, impessoalidade, moralidade, eficiência e razoabilidade com vistas a alcançar o interesse público.

Para melhor compreender o regime jurídico da Administração Pública e conseqüentemente - do concurso público, cabe esclarecer o significado normativo de princípio.

\begin{abstract}
Assim, as regras são normas que definem concretamente as situações sobre as quais buscam incidir, caracterizando-se como normas de comportamento e representando razões imperativas para agir.

Já os princípios possuem uma concepção genérica que serve de fundamento para a elaboração de uma regra para o caso concreto: são normas de argumentação e razões prima facie para agir.

(...)

Também possui força normativa e consiste num enunciado deôntico, ou seja, voltado para o 'dever ser', mas, em razão de possuir um grau mais elevado de generalidade, representa um indicativo de direção, um norte a ser seguido e aplicado nos casos concretos, em resumo, é uma norma de argumentação que admite aplicação em diferentes graduações, de acordo com o peso que possuir na ocasião, e exigindo para a sua aplicação um processo de concretização sucessiva, passando por subprincípios até alcançar o grau de densidade próprio das regras. (DIAS, 2008, p. 32-33).
\end{abstract}

Assim sendo, o regime jurídico administrativo é composto por um conjunto sistematizado de princípios e regras que impossibilita o gestor público de dispor livremente do patrimônio público e vincula os atos do gestor público à satisfação de interesses públicos, até mesmo quando recruta e seleciona para compor seus quadros funcionais.

Com base no exposto acima, caracterizados os servidores públicos como ativo estratégico da Administração Pública ao utilizar a gestão por competências na concretização do interesse público, o presente estudo prosseguirá em seu intuito de identificar se a perspectiva reducionista do concurso público como teste de conhecimento pode avançar sem descuidar da observância ao sistema de mérito e aos princípios jurídicos que o regem para uma seleção de servidores públicos por competências. 


\section{METODOLOGIA}

\subsection{Tipo de pesquisa}

Vergara (2004) classifica as pesquisas segundo seus fins e seus meios. O presente estudo se propõe a identificar um instrumento que selecione servidores para a Administração Pública por meio da avaliação de competências e analisar sua compatibilidade com o regime jurídico do concurso público federal. Considerando-se que não foram localizados estudos que exponham os óbices jurídicos da seleção de servidores por competências nesse âmbito, esta pesquisa caracteriza-se, quanto aos fins, como exploratória e descritiva.

No que se refere aos meios, trata-se de uma pesquisa documental. A busca bibliográfica sobre a administração pública, a seleção de pessoas e o regime jurídico do concurso público, disponíveis em livros, revistas e rede eletrônica, serviu de base para aprimorar o referencial teórico e a metodologia, além de fornecer dados para a análise.

\subsection{Corpus da análise documental}

A pesquisa documental se utilizou de documentos do Centro Latino-americano de Administração para o Desenvolvimento (CLAD), da Organização para a Cooperação e Desenvolvimento Econômico (OCDE), da República Dominicana, da Administração Pública Federal (APF), do Superior Tribunal de Justiça (STJ) e/ou do Supremo Tribunal Federal (STF) tais como notícias, procedimentos, normas, decisões judiciais e demais documentos que tenham como objeto a seleção de servidores públicos por competências ou o regime jurídico do concurso público federal, possibilitando um conhecimento mais detalhado das informações levantadas na pesquisa bibliográfica.

Foram analisados documentos, considerados aqui em seu sentido amplo, que abordam a seleção de servidores por competências em países-membros do CLAD e da OCDE, as normas que tratam do regime jurídico do concurso público e decisões do STJ e do STF que aplicaram essas normas a casos concretos.

Dentre eles, foram selecionados os documentos que: (a) abordam a seleção de servidores por competências na República Dominicana, pois, dentre os países que admitem legalmente essa prática na Administração Pública, é aquele que apresenta regime jurídico mais próximo do brasileiro; (b) tratam de normas de concurso público referentes ao processo 
de seleção de servidores públicos federais; e (c) decidam questões judiciais que abordem a aplicação das normas de concurso público referentes ao processo de seleção de servidores públicos.

\subsection{Procedimento de coleta de dados}

A coleta de dados foi realizada, principalmente, por intermédio da rede eletrônica em visita aos sítios www.clad.org.ve, www.oecd.org, www.seap.gob.do, www.conare.gob.do, $\underline{\text { www.planejamento.gov.br, }}$ www.enap.gov.br, www.stj.jus.br e www.stf.jus.br - e/ou da solicitação direta aos órgãos e organizações relacionados no primeiro tópico deste capítulo.

\subsection{Análise de dados}

As técnicas da análise de conteúdo foram utilizadas para analisar os dados. Para Bardin (2009), além dos significados imediatos da comunicação, a análise de conteúdo constitui-se em um conjunto de metodologias que visa analisar o discurso além de sua apresentação objetiva.

Primeiramente, pré-análise, com a reunião dos documentos localizados ou disponibilizados pelas organizações elencadas anteriormente, de forma a identificar as restrições jurídicas ao uso de um instrumento de seleção de servidores públicos por competências admitido no serviço público de países-membros do CLAD e da OCDE na Administração Pública Federal do Brasil.

Em seguida, exploração do material, subdivida em recorte (escolha das unidades) e classificação (escolha da categoria), com vistas a classificar a categorização de conjuntos de possíveis óbices jurídicos ao uso de um determinado instrumento de seleção por competências no concurso público federal.

Por fim, foi realizado o tratamento dos dados, atribuindo significado a eles por meio da interpretação ao considerar não somente a literalidade dos documentos, mas também o conteúdo não necessariamente declarado por eles. 


\section{RESULTADOS}

O presente capítulo reúne as informações retiradas dos documentos analisados que abordam: (a) a seleção de servidores públicos por competências prevista legalmente na Administração Pública da República Dominicana; (b) as normas que regem o processo de seleção de servidores públicos no âmbito da APF; e (c) as decisões do STF e do STJ sobre os conflitos judiciais decorrentes do uso da entrevista como instrumento de seleção em concursos públicos federais.

\subsection{Seleção de servidores públicos por competências}

A República Dominica foi fundada em 1844 e localiza-se na parte oriental da Ilha de Santo Domingo, ou "La Española", que compartilha com a República do Haiti no Arquipélago das Antilhas, América Central.

A "Secretaría de Estado de Administración Pública" (SEAP) é o órgão da Administração Pública Dominicana responsável pelos concursos públicos para os cargos da Carreira Administrativa.

No serviço público dominicano, o processo de seleção mais rigoroso é o realizado para entrar na Carreira Administrativa ou nas Carreiras Especiais. Existem duas formas de se ingressar na Carreira Administrativa: o concurso e a seleção interna.

Com respeito ao concurso, a lei estabelece que todos os cidadãos que aspirem ocupar posições de carreira na Administração Pública Central devem demonstrar em concurso de livre concorrência que contam com os méritos necessários para desempenhar o cargo.

Em estudo realizado pela subárea de Recursos Humanos da área de Administração Pública da "Comisión Presidencial para la Reforma y Modernización del Estado" (CPRyME) em 1999, foram identificadas 11 competências gerenciais, classificadas em 7 Competências de Desenvolvimento e Controle e 4 Competências de Atitude que o gestor público da República Dominicana deve possuir. O perfil resultante foi o seguinte:

- Competências de Desenvolvimento e Controle: Liderança e Gestão Estratégica, Gerência de Mudança, Capacidade de Planejamento, Gestão de Processos, Gestão de Recursos Humanos, Trabalho em Equipe, Administração de Recursos; 
- Competências de Atitude: Orientação ao Cliente, Integridade e Honestidade, Desenvolvimento de Relações, Relações com Colaboradores.

Portanto, reconhecendo que o conhecimento, a experiência e as habilidades por si só não bastam, esse processo de seleção de candidatos a fazer carreira no serviço público foi consideravelmente enriquecido com um Modelo de Competências Comportamentais e Técnicas elaborado com base no perfil do cargo. Nesse sentido, a Lei $n^{\circ} 41$ de 16/01/2008, assim dispõe:

\footnotetext{
Artigo 40. As provas e os instrumentos de avaliação que serão aplicados aos candidatos deverão identificar de maneira objetiva os conhecimentos, atitudes, habilidades, destrezas e o grau de adaptação dos candidatos em relação à natureza dos cargos a serem ocupados. Para isso, a Secretaria de Estado da Administração Pública determinará previamente os critérios, métodos e técnicas de avaliação. [Tradução nossa].
}

Essa lei foi regulamentada pelo Decreto $n^{\circ} 524$ de 21/07/2009, que estabelece os princípios, as normas, os procedimentos técnicos e a metodologia que regem a aplicação do Subsistema de Recrutamento e Seleção de Pessoal para ocupar Cargos da Carreira Administrativa Geral na Administração Pública Dominicana.

Esse regulamento define competência como "um conjunto de características observáveis e desenvolvidas em forma de conhecimentos, habilidades, destrezas e atitudes das pessoas que se expressam através de comportamentos e ações específicos cuja presença potencializa o êxito das pessoas no trabalho que realizam".

No que toca às fases de seleção para identificar, da forma mais objetiva possível, os conhecimentos e as competências dos candidatos a ocupar cargos da Carreira Administrativa, as seguintes fases são elencadas no art. 36, podendo ser superadas apenas quando o candidato completa setenta por cento (70\%) dos pontos: 1) avaliação curricular e do histórico laboral; 2) aplicação de provas técnicas ou de conhecimentos; 3) aplicação de questionários de personalidade; 4) aplicação de provas práticas; 5) apresentação de projetos de trabalho; 6) entrevistas de seleção; e 7) outros meios confiáveis de comprovação de méritos.

Sobre a entrevista de seleção, o Decreto no 524-09 a conceitua como "reunião agendada para estabelecer um diálogo entre o candidato e o jurado do concurso; onde este último procura averiguar se o primeiro reúne os requisitos do cargo disponível, e vice-versa".

Em painel intitulado "Perfil de competencias del gerente público en República Dominicana: competencias claves y su impacto en el proceso de selección", apresentado no XII Congresso Internacional do CLAD na República Dominicana, Loudes Peña destaca, 
dentre os instrumentos mais utilizados para avaliar as competências do candidato e comparálas com o Perfil de Competências do Cargo, as entrevistas comportamentais e os centros de avaliação.

Assim sendo, considerando que a entrevista é o instrumento de seleção previsto expressamente na norma da Administração Pública Dominicana que trata sobre o concurso público para a Carreira Administrativa, escolhe-se a entrevista comportamental como instrumento de seleção por competências a ser confrontado com o regime jurídico do concurso público federal.

\subsection{Normas de seleção de servidores públicos da APF}

Para se verificar se a entrevista comportamental pode ser utilizada no concurso público federal, faz-se necessário confirmar se ela não afronta alguma norma de seu regime jurídico. Assim, em apertada síntese, são apresentadas as normas e princípios que regem o processo de escolha e classificação dos candidatos recrutados para ocupar um cargo público efetivo ou vitalício na APF.

A APF não dispõe de lei específica que discipline o concurso público. Portanto, as normas e princípios que disciplinam a seleção de servidores públicos estão dispersas no sistema de normas que rege a APF.

Sua principal fonte é a Constituição da República Federativa do Brasil de 1988 (CF/88), seguida pela Lei Federal nº 8.112 de 1990 e pela Lei Federal nº 9.784 de 1999. Ainda que não trate especificamente sobre o processo de seleção de servidores públicos, o Decreto Presidencial $\mathrm{n}^{\circ} 4.175$ de 2002 delega competência ao Ministro de Estado do Planejamento, Orçamento e Gestão para autorizar a realização de concursos públicos e a nomeação de candidatos, bem como estabelecer suas respectivas normas e procedimentos. Essa competência regulamentar foi exercida por meio das Portarias $n^{\circ} 450$ de 2002 e n 45 de 2003, mas elas abordam apenas questões referentes ao processo de recrutamento.

A CF/88 adota o sistema de mérito em seu artigo 37, incisos I e II. Esses dispositivos também são conhecidos por tornarem expresso o princípio do amplo acesso aos cargos públicos. Na medida em que exige que o concurso público selecione os candidatos por intermédio de provas - combinadas ou não com títulos - segundo a natureza e complexidade do cargo público vago, o inciso II aborda o processo de seleção, enquanto o inciso I restringe o acesso aos cargos públicos ao cumprimento dos requisitos previstos em lei: 
I - os cargos, empregos e funções públicas são acessíveis aos brasileiros que preencham os requisitos estabelecidos em lei, assim como aos estrangeiros, na forma da lei;

II - a investidura em cargo ou emprego público depende de aprovação prévia em concurso público de provas ou de provas e títulos, de acordo com a natureza e a complexidade do cargo ou emprego, na forma prevista em lei, ressalvadas as nomeações para cargo em comissão declarado em lei de livre nomeação e exoneração. [Grifos nossos]

A Lei $n^{\circ} 8.112 / 90$, por sua vez, acrescenta ao disposto na $\mathrm{CF} / 88$ : (i) os requisitos básicos para o ingresso (investidura) em cargo público; (ii) o respeito à ordem de classificação definida pelas avaliações; (iii) a possibilidade dele ser realizado em duas etapas; (iv) sua vinculação à lei e ao regulamento do plano de carreira em que pode estar incluído o cargo público; e (v) definir que o concurso público terá as condições de sua realização previstas em edital que deve ser publicado. Essas previsões estão nos artigos $5^{\circ}, 10,11$ e $12, \S 1^{\circ}$ :

Art. 5o São requisitos básicos para investidura em cargo público:

I - a nacionalidade brasileira;

II - o gozo dos direitos políticos;

III - a quitação com as obrigações militares e eleitorais;

IV - o nível de escolaridade exigido para o exercício do cargo;

V - a idade mínima de dezoito anos;

VI - aptidão física e mental.

$\S 1$ o As atribuições do cargo podem justificar a exigência de outros requisitos estabelecidos em lei.

(...)

Art. 10. A nomeação para cargo de carreira ou cargo isolado de provimento efetivo depende de prévia habilitação em concurso público de provas ou de provas e títulos, obedecidos a ordem de classificação e o prazo de sua validade.

Parágrafo único. Os demais requisitos para o ingresso e o desenvolvimento do servidor na carreira, mediante promoção, serão estabelecidos pela lei que fixar as diretrizes do sistema de carreira na Administração Pública Federal e seus regulamentos.

Art. 11. O concurso será de provas ou de provas e títulos, podendo ser realizado em duas etapas, conforme dispuserem a lei e o regulamento do respectivo plano de carreira, condicionada a inscrição do candidato ao pagamento do valor fixado no edital, quando indispensável ao seu custeio, e ressalvadas as hipóteses de isenção nele expressamente previstas.

Art. 12. O concurso público terá validade de até 2 (dois) anos, podendo ser prorrogado uma única vez, por igual período.

$\S 10$ O prazo de validade do concurso e as condições de sua realização serão fixados em edital, que será publicado no Diário Oficial da União e em jornal diário de grande circulação.

(...). [Grifos nossos] 
Um exemplo de carreira que prevê outros requisitos para a investidura no cargo é a carreira de policial federal. O artigo $9^{\circ}$ da Lei $n^{\circ} 4.878$ de 1965 , ainda vigente, acrescenta, aos requisitos básicos dispostos no art. $5^{\circ}$ da Lei $n^{\circ} 8.112 / 90$, os seguintes:

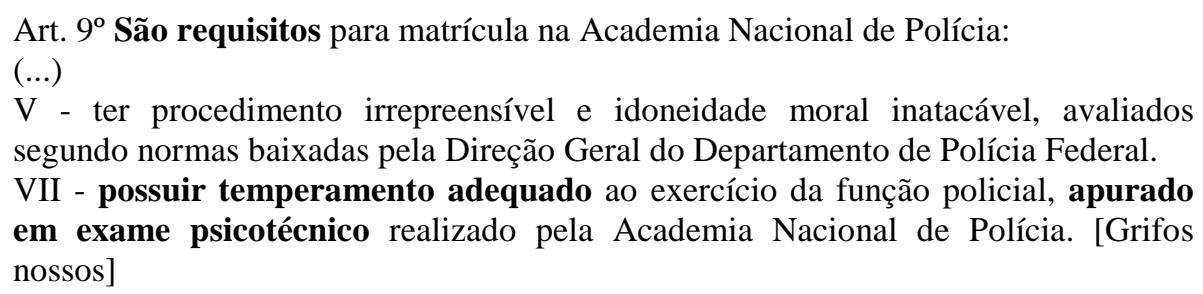

Como o concurso público é um processo administrativo, ele também se subordina, no que for cabível, à Lei ${ }^{\circ}$ 9.784, sobretudo no que toca aos princípios de seu art. $2^{\circ}$, já que os seus incisos expressam de forma mais concreta os princípios eleitos no caput:

Art. 2o A Administração Pública obedecerá, dentre outros, aos princípios da legalidade, finalidade, motivação, razoabilidade, proporcionalidade, moralidade, ampla defesa, contraditório, segurança jurídica, interesse público e eficiência.

Parágrafo único. Nos processos administrativos serão observados, entre outros, os critérios de:

I - atuação conforme a lei e o Direito;

II - atendimento a fins de interesse geral, vedada a renúncia total ou parcial de poderes ou competências, salvo autorização em lei;

III - objetividade no atendimento do interesse público, vedada a promoção pessoal de agentes ou autoridades;

IV - atuação segundo padrões éticos de probidade, decoro e boa-fé;

V - divulgação oficial dos atos administrativos, ressalvadas as hipóteses de sigilo previstas na Constituição;

VI - adequação entre meios e fins, vedada a imposição de obrigações, restrições e sanções em medida superior àquelas estritamente necessárias ao atendimento do interesse público;

VII - indicação dos pressupostos de fato e de direito que determinarem a decisão;

VIII - observância das formalidades essenciais à garantia dos direitos dos administrados;

IX - adoção de formas simples, suficientes para propiciar adequado grau de certeza, segurança e respeito aos direitos dos administrados;

$\mathrm{X}$ - garantia dos direitos à comunicação, à apresentação de alegações finais, à produção de provas e à interposição de recursos, nos processos de que possam resultar sanções e nas situações de litígio;

(...)

XIII - interpretação da norma administrativa da forma que melhor garanta o atendimento do fim público a que se dirige, vedada aplicação retroativa de nova interpretação. [Grifos nossos]

Portanto, mais do que normas diretas sobre o processo de seleção do concurso público, esse processo é regido por princípios, especialmente o princípio da legalidade estrita, isto é, os critérios ou requisitos para o ingresso no cargo público devem estar expressamente previstos em lei.

Dessa forma, torna-se imprescindível conhecer como os Tribunais Superiores estão aplicando as normas lacunosas do processo de seleção e seus princípios a problemas concretos envolvendo a entrevista em concursos públicos. 


\subsection{Jurisprudência sobre seleção de servidores públicos}

Uma circunstância que comumente vem a ser enfrentada pelos juízes e tribunais brasileiros é a relativa aos métodos de avaliação e de avaliação empregados nos concursos públicos, assim como ao direito de controle administrativo sobre tais atos, por intermédio de recursos.

A forma de avaliação e de correção das provas dos concursos deve ser efetivada diante de parâmetros objetivos, não dando a menor margem para que algum membro da Banca Examinadora possa impregnar de subjetivismo as respostas das perguntas, favorecendo algum dos candidatos em detrimento dos demais, devendo, ainda, ser dado ao candidato o direito de recorrer da decisão administrativa referente à correção de sua prova.

As decisões judiciais do STJ que tratam da entrevista vedam o enfoque subjetivo, sigiloso e irrecorrível das entrevistas utilizadas como instrumento de seleção de servidores públicos federais, bem como sua necessária vinculação ao exame psicotécnico: ADMINISTRATIVO. CONCURSO PÚBLICO. EXAME PSICOTÉCNICO.
CARÁTER SIGILOSO DA ENTREVISTA. ART. 37 DA CF/1988.
INFRINGÊNCIA. MOTIVAÇÃO POSTERIOR. IMPROPRIEDADE. 1. Não se
vislumbra violação do artigo 535 do Código de Processo Civil, posto que ausentes
quaisquer vícios no acórdão embargado. Os embargos de declaração não se prestam
ao reexame de matéria já decidida. 2 . É uníssono o entendimento proclamado no
âmbito deste Tribunal no sentido de não admitir exame psicotécnico segundo
critérios subjetivos e sigilosos, devendo impor critérios objetivos, que não
permitam procedimento seletivo discriminatório pelo eventual arbítrio. 3. O ato
administrativo deve ser fundamentado e suas razões contemporâneas. 4. O
reconhecimento do caráter sigiloso e irrecorrível do exame psicotécnico determinado
pelo edital que regula o concurso para o provimento de cargo policial militar não
conduz ao automático ingresso dos candidatos nele reprovados no Curso de
Formação. 5. Recurso parcialmente provido (Recurso Especial $\mathrm{N}^{\circ} 462.676$ - RS,
Relator Ministro Paulo Medina, julgamento em $23 / 03 / 2004)$. [Grifos nossos]

CONCURSO PÚBLICO. EXAME PSICOTÉCNICO. CANDIDATO CONSIDERADO NÃO RECOMENDADO. 1. Ilegalidade da aplicação do exame psicotécnico, realizado em moldes nitidamente subjetivos. 2. O desdobramento do exame psicotécnico em duas fases- bateria de testes e entrevista, não pode decidir pela recomendação ou não do candidato, em virtude da natureza subjetiva e conseqüentemente discriminatória da entrevista. 3. Recurso improvido (Recurso Especial No 27.866 - DF, Relator Ministro Edson Vidigal, julgamento em 02/10/1995). [Grifos nossos]

Para que possa ser viabilizado durante o concurso público, o exame psicotécnico deverá estar previsto em lei, pois o edital não pode criar limitações ao acesso do cargo em previsão legal. Assim já se pronunciou o STF (Recurso Extraordinário 188234 - DF, Relator Ministro Néri da Silveira, julgamento em 19/03/2002): “o exame psicotécnico pode ser estabelecido para concurso público desde que seja feito por lei, e que tenha por base critérios objetivos de reconhecido caráter científico, devendo existir, inclusive, a possibilidade de 
reexame". Inclusive, depois de inúmeras decisões nesse sentido, a Corte Suprema editou, em 24/09/2003, a Súmula n 686 dizendo que "só por lei se pode sujeitar a exame psicotécnico a habilitação de candidato a cargo público" [Grifos nossos]. Trechos de decisões mais recentes confirmam esse entendimento:

Concurso público: além da necessidade de lei formal prevendo-o como requisito para o ingresso no serviço público, o exame psicotécnico depende de um grau mínimo de objetividade e de publicidade dos atos em que se desdobra: precedentes. (Agravo Regimental no Recurso Extraordinário No 417.019 - SE, Relator Ministro Sepúlveda Pertence, julgamento em 14/08/2007). No mesmo sentido: Agravo Regimental no Agravo de Instrumento No 595.541 - MG, Relator Ministro Joaquim Barbosa, julgamento em 16/06/2009. [Grifos nossos]

O exame psicotécnico, especialmente quando possuir natureza eliminatória, deve revestir-se de rigor científico, submetendo-se, em sua realização, à observância de critérios técnicos que propiciem base objetiva destinada a viabilizar o controle jurisdicional da legalidade, da correção e da razoabilidade dos parâmetros norteadores da formulação e das conclusões resultantes dos testes psicológicos, sob pena de frustrar-se, de modo ilegítimo, o exercício, pelo candidato, da garantia de acesso ao Poder Judiciário, na hipótese de lesão a direito. Precedentes. (Agravo Regimental no Agravo de Instrumento No 625.617 - DF, Relator Ministro Celso de Mello, julgamento em 19/06/2007). [Grifos nossos]

Portanto, as menções diretas à entrevista como instrumento de seleção na jurisprudência dos Tribunais Superiores a consideram como parte dos exames psicotécnicos que avaliam requisitos de acesso a cargos públicos e não como prova, restringindo a sua utilização a concursos públicos federais para os cargos públicos que prevejam o exame psicotécnico como requisito. 


\section{ANÁLISE DOS RESULTADOS}

Com vistas a facilitar a apresentação dos resultados desta pesquisa, os dados foram sequienciados em categorias. A primeira delas é a entrevista comportamental como instrumento de seleção de servidores por competências.

Considerando que na entrevista comportamental são realizadas perguntas abertas e específicas a partir das competências necessárias para o cargo, esse instrumento obtém descrições de exemplos comportamentais ocorridos na vida do candidato que indicam evidências de uma competência, possibilitando a escolha de quem apresenta a menor lacuna (gap) entre o perfil pessoal e o do cargo e facilitando o alinhamento entre as competências funcionais e organizacionais.

Diversamente de outros instrumentos que não alcançam o viés das atitudes na análise do perfil do candidato, a entrevista comportamental é capaz de ir além dos conhecimentos e habilidade dos candidatos.

A utilização da entrevista na seleção de servidores públicos para a Administração Pública da República Dominicana está prevista no art. 36 do Decreto no 524-09 como uma fase classificatória e eliminatória. No entanto, como em qualquer fase, o candidato somente prossegue no concurso se for avaliado com, no mínimo, setenta por cento (70\%) dos pontos.

Seria possível, contudo, que esse instrumento da Administração Pública Comparada fosse aplicado no regime jurídico do concurso público federal? A resposta a essa pergunta qualifica como restritivas as seguintes categorias: princípio da legalidade, subjetividade e sigilo da entrevista comportamental (instrumento de seleção por competências).

Portanto, com base no que foi identificado no capítulo anterior, se a entrevista comportamental for enquadrada como exame psicotécnico, seria concebida como um requisito de investidura e não como instrumento de seleção de servidores por competências, encontrando óbice no regime jurídico da APF em razão de sua ausência de previsão legal, isto é, afrontando o princípio da legalidade, previsto no caput da Lei no 9.784 de 1999.

Portanto, como o artigo 37, inciso I, da CF/88, dá acesso aos cargos públicos a toda e qualquer pessoa e confere à lei o papel de restringir a forma de acesso a eles, um instrumento de seleção do concurso público que impeça a investidura e que não esteja previsto em lei 
afrontaria esse dispositivo constitucional e o candidato preterido com base nele poderia ser facilmente amparado pelo Poder Judiciário em seu desejo de reparar o pretenso dano sofrido.

Dessa forma, ainda que a decisão sobre os instrumentos de seleção e avaliação dos resultados a serem utilizados no concurso público esteja relacionada à questão técnicoadministrativa (função administrativa), por essa decisão se subordinar ao princípio da legalidade previsto no regime jurídico da Administração Pública, essa opção técnica pode ser decidida pelo Poder Judiciário no exercício da função jurisdicional do Estado caso desrespeite algum princípio jurídico.

Nesse sentido, aplicada atualmente em concursos para cargos públicos federais em que a lei ou o regulamento da carreira preveja o uso do exame psicotécnico como requisito específico para ingresso no cargo, são evidenciadas as categorias restritivas referentes à subjetividade da entrevista e ao sigilo da entrevista. Nesse caso, conforme a jurisprudência analisada, faz-se necessário que esse instrumento se paute em critérios objetivos e respeite o princípio da publicidade. Dessa forma, afasta-se a subjetividade e permite-se o respeito aos princípios da publicidade, da impessoalidade, da isonomia, do contraditório e da ampla defesa.

Seguindo essa linha de raciocínio, é possível constatar que a principal dificuldade jurídica para a aplicação do modelo de gestão por competências nos processos seletivos da APF não decorre da existência de restrições legais que inibem a consideração de fatores diferentes do conhecimento acumulado na seleção de servidores públicos, mas sim do entendimento jurisprudencial sobre a natureza jurídica da entrevista comportamental, já que não sendo considerada prova ou avaliação é reconhecida como exame da aptidão mental do candidato.

Aparentemente, isso leva a crer que a APF ainda não goze de flexibilidade suficiente para usar a entrevista comportamental como instrumento de seleção em concursos públicos, devendo seus dirigentes de gestão de pessoas superar a lacuna legal apontada para viabilizar seu uso em certames para todo e qualquer cargo público federal. Contudo, chega-se a essa conclusão apenas se ela for considerada exame psicotécnico, podendo ser concebida posição diversa se for verificado que a entrevista tratada nas decisões judiciais não se enquadra na entrevista prevista na República Dominicana.

Ultrapassando a barreira da literalidade dos documentos analisados, verifica-se que a entrevista comportamental pode ser concebida como uma dentre as provas do concurso 
público e não um requisito a ser preenchido no acesso ao cargo público: categoria entrevista comportamental como prova de concurso público.

A diversidade entre a natureza da entrevista do exame psicotécnico e aquela da entrevista comportamental da seleção por competências pode ser percebida de diversas formas. A primeira delas refere-se ao objeto da entrevista. Enquanto a entrevista do exame psicotécnico constitui apenas um pressuposto para a assunção dos cargos públicos (requisito para investidura), a entrevista comportamental é propriamente uma avaliação dos candidatos em termos de competitividade das competências identificadas (prova). Em segundo lugar, quanto ao efeito de seu resultado, aquela tem caráter exclusivamente eliminatório, já a comportamental apresenta tanto caráter classificatório quanto eliminatório. Por último, no que se refere àquilo que é medido, destaca-se que a entrevista de que tratam as decisões judiciais analisadas mede a aptidão mental, por sua vez, a entrevista comportamental afere as competências funcionais do candidato. 


\section{CONCLUSÃO}

O presente estudo monográfico afrontou, de forma modesta, uma importante questão para a Administração Pública Brasileira que passa atualmente pela reforma da gestão pública e objetiva se tornar inovadora, flexível, eficiente e eficaz: a substituição da avaliação de conhecimentos pela avaliação de competências na seleção de servidores públicos federais é compatível com o atual regime jurídico do concurso público?

Não localizando qualquer experiência de seleção por competências nas esferas estaduais e municipais do Brasil, foram localizadas experiências dessa forma de seleção na Administração Pública de países do sistema anglo-americano e sua previsão legal na República Dominica - país que, como o Brasil, adota o sistema da statute law. No tópico 4.1, a forma que esse país prevê a seleção de servidores públicos por competências foi descrita identificando dois instrumentos de seleção por competências e, conseqüentemente, atendendo ao primeiro objetivo específico proposto, conforme se demonstrou na análise de resultados.

Os outros dois objetivos foram alcançados nos tópicos 4.2 e 4.3, igualmente detalhados na análise de resultados. Eles apontaram as normas e princípios que regem o processo de escolha e classificação dos candidatos recrutados para ocupar um cargo público efetivo ou vitalício da APF, além das decisões do STF e do STJ sobre os conflitos judiciais decorrentes desse processo.

Dessa forma, ficou constatado que a principal dificuldade jurídica para a aplicação do modelo de gestão por competências nos processos seletivos da APF não decorre da existência de restrições legais que inibem a consideração de fatores diferentes do conhecimento acumulado na seleção de servidores públicos, mas sim do entendimento jurisprudencial sobre a natureza jurídica da entrevista comportamental, já que se não for considerada prova ou avaliação, mas reconhecida como requisito básico para investidura no cargo, encontra óbice no regime jurídico do concurso público federal.

Assim, conforme foi aqui demonstrado, a entrevista comportamental só encontrará obstáculo em sua aplicação como instrumento de seleção por competências de servidores públicos federais efetivos ou vitalícios se for igualada aos exames psicotécnicos, que aferem a aptidão mental do candidato, têm caráter exclusivamente eliminatório e constituem um 
requisito específico para a investidura em alguns cargos públicos - como aqueles dos policiais federais.

Dessa forma, ficou constatado que a APF dispõe de flexibilidade nas normas do concurso público federal para aplicar o modelo de gestão por competências nos processos seletivos, não existindo restrições jurídicas que inibam a utilização, na seleção de servidores públicos, de fatores diferentes do conhecimento acumulado. Há, na verdade, a ausência de um diálogo profundo entre dirigentes de gestão de pessoas da APF e seus órgãos de apoio jurídico na busca por alternativas que viabilizem a prática da seleção de servidores públicos por competências, como previsto na Administração Pública da República Dominicana.

Por fim, é preciso organizar esforços para que os candidatos recrutados demonstrem, além do domínio dos conhecimentos relevantes, a posse das habilidades e atitudes compatíveis com as suas futuras atribuições. A necessidade do desenvolvimento de metodologias adequadas à identificação das competências organizacionais e ao mapeamento de competências dos servidores surge como desafio adicional não apenas para as atividades de recrutamento e seleção, mas para a integração da abordagem da competência a todos os subsistemas de gestão de pessoas da APF.

Finalmente, tendo em vista a complexidade e relevância do tema aqui abordado e as limitações da presente pesquisa, destaca-se que a seleção por competências na APF ainda exige diversos estudos antes que possa ser aplicada. Dentre eles destaca-se, por exemplo, o estudo aprofundado dos instrumentos de seleção por competências que seja mais adequado ao contexto da APF. 


\section{REFERÊNCIAS}

ADMINISTRAÇÃO. In: HOUAISS, Antonio; VILLAR, Mauro de Salles. Dicionário Houaiss da Língua Portuguesa. Rio de Janeiro: Objetiva, 2001.

ADMINISTRAÇÃO PÚBLICA. In: BOBBIO, Norberto; MATTEUCI, Nicola; PASQUINO, Gianfranco. Dicionário de Política. 6. ed. Brasília: Editora Universidade de Brasília, 2003.

BARDIN, Laurence. Trad. Luís Antero Reto e Augusto Pinheiro. Análise de conteúdo. 4. ed. rev. e atual. Lisboa/Portugal: Edições 70, 2009.

BERGUE, Sandro Trescastro. Gestão de pessoas em organizações públicas. 2. ed. rev. e atual. Caxias do Sul, RS: Educs, 2007.

BOHLANDER, George; SNELL, Scolt; SHERMAN, Arthur. Trad. Maria Lúcia G. Leite Rosa. Administração de recursos humanos. São Paulo: Pioneira Thomson Learning, 2005.

BRANDÃO, Hugo Pena; GUIMARÃES, Tomás de Aquino. Gestão de competências e gestão de desempenho: tecnologias distintas ou instrumentos de um mesmo construto? Revista de Administração de Empresas - RAE. São Paulo, v. 41, n. 1, p. 8-15, jan./mar. 2001.

; BAHRY, Carla P. Gestão por competências: métodos e técnicas para mapeamento de competências. Revista do Serviço Público. Brasília, 56 (2), p 179-194, abr./jun. 2005.

Aprendizagem, contexto, competência e desempenho: um estudo multinível. Tese de doutorado em psicologia. Brasília, Universidade de Brasília, 2009.

BRASIL. Superior Tribunal de Justiça - STJ. Disponível em: <http://www.stj.jus.br>. Acesso: 5 set. 2009.

BRASIL. Supremo Tribunal Federal - STF. Disponível em: <http://www.stf.jus.br>. Acesso: 5 set. 2009.

CAMARENA Thelma. Evaluación de competencias. XII Congresso Internacional del CLAD sobre la Reforma Del Estado y de la Administración Pública. São Domingo, República Dominicana. 30 Out. - 2 Nov. 2007.

CARVALHO, Ieda Maria Vecchioni; PASSOS, Antônio Eugênio V. Mariani; SARAIVA, Suzana Barros Corrêa. Recrutamento e seleção por competências. Rio de Janeiro: FGV, 2008.

CARVAlHO FILHO, José dos Santos. Manual de Direito Administrativo. 15. ed. Rio de Janeiro: Lumen Juris, 2006.

COELHO, Daniela Mello. Administração pública gerencial e direito administrativo. Belo Horizonte: Mandamentos, 2004. 
COELHO, Inocêncio Mártires; MENDES, Gilmar Ferreira; BRANCO, Paulo Gustavo Gonet. Curso de Direito Constitucional. São Paulo: Saraiva, 2008.

DI PIETRO, Maria Sylvia Zanella. Direito Administrativo. 17. ed. São Paulo: Atlas, 2004.

DIAS, Jefferson Aparecido. Princípio da eficiência e moralidade administrativa: a submissão do princípio da eficiência à moralidade administrativa na Constituição Federal de 1988. 2. ed. rev. e atual. Curitiba: Juruá, 2008.

FAISSAL, Reinaldo. et al. Atração e seleção de pessoas. Rio de Janeiro: FGV, 2005.

FERLIE, Ewan. et al. Trad. Sara Rejane de Freitas Oliveira. A nova administração pública em ação. Brasília: Editora Universidade de Brasília; ENAP, 1999.

FERRAZ, David. A alta administração pública no contexto da evolução dos modelos de Estado e de administração. Oeiras: INA, 2008.

FLICK, Uwe. Trad. Joice Elias Costa. Introdução à pesquisa qualitativa. 3. ed. Porto Alegre: Artmed, 2009.

FREITAS, Liziane Castilhos de Oliveira. Avaliação psicológica em concurso público: relações com o desempenho em treinamento de bombeiros. Dissertação de mestrado em psicologia. Brasília: Universidade de Brasília, 2004.

GUIMARÃES, Tomás de Aquino. A nova administração pública e a abordagem da competência. Revista de Administração Pública. Rio de Janeiro: FGV, 34(3), p. 125-140, mai./jun. 2000.

LIMONGI-FRANÇA, Ana Cristina; ARELLANO, Eliete Bernal. Os processos de recrutamento e seleção. In: FLEURY, Maria Tereza Leme (Org.). As pessoas na organização. São Paulo: Gente, 2002.

LONGO, Francisco. Mérito e flexibilidade: a gestão das pessoas no setor público. São Paulo: FUNDAP, 2007.

MACHADO JÚNIOR, Agapito. Concursos públicos. São Paulo: Atlas, 2008.

MAIA, Márcio Barbosa; QUEIROZ, Ronaldo Pinheiro de. O regime jurídico do concurso público e o seu controle jurisdicional. São Paulo: Saraiva, 2007.

MATIAS-PEREIRA, José. Curso de administração pública: foco nas instituições e ações governamentais. São Paulo: Atlas, 2008.

MELlO, Celso Antônio Bandeira de. Curso de Direito Administrativo. 25. ed. São Paulo: Malheiros, 2008.

MELO, Frederico Jorge Gouveia de. Admissão de pessoal no serviço público. Belo Horizonte: Fórum, 2006.

MILKOVICH, George T.; BOUDREAU, John W. Trad. Reynaldo C Marcondes. Administração de recursos humanos. São Paulo: Atlas, 2008. 
MORAES, Alexandre de. Direito Constitucional. 18. ed. São Paulo: Atlas, 2005.

NADER, Paulo. Introdução ao estudo do direito. Rio de Janeiro: Forense, 1996.

PEÑA, Lourdes. Perfil de competencias del gerente público en República Dominicana: competencias claves y su impacto en el processo de selección. XII Congresso Internacional del CLAD sobre la Reforma Del Estado y de la Administración Pública. São Domingo, República Dominicana. 30 Out. - 2 Nov. 2007.

PEREIRA, Luiz Carlos. Trad. Maria Cristina Godoy. Construindo o Estado republicano: democracia e reforma da gestão pública. Rio de Janeiro: Editora FGV, 2009.

PLOYHART, Robert E. Staffing in the 21st Century: new challenges and strategic ppportunities. Journal of Management, v. 32, n. 6. p. 868-897, Dez 2006.

PÚBLICO. In: HOUAISS, Antonio; VILLAR, Mauro de Salles. Dicionário Houaiss da Língua Portuguesa. Rio de Janeiro: Objetiva, 2001.

REPÚBLICA DOMINICANA. Decreto n. 524, 21 jul. 2009. Estabelece os princípios, as normas, os procedimentos técnicos e a metodologia que regem a aplicação do Subsistema de Recrutamento e Seleção de Pessoal para ocupar Cargos da Carreira Administrativa Geral na Administração Pública Dominicana. Disponível em: <http://www.seap.gob.do/ contentmanager/Archivos/Documentos/Decreto\%20524-09.pdf>. Acesso em: 4 set. 2009. Original espanhol.

REPÚBLICA DOMINICANA, Congresso Nacional. Lei n. 41, 4 jan. 2008. Disponível em: <http://www.conare.gob.do/Publicaciones/LibrosFolletos/Leyes/tabid/198/Default.aspx>. Acesso em: 4 set. 2009. Original espanhol.

SALGADO, J. F. Personnel selection at the beginning of the new millennium. International journal of selection and assessment, 8(4), p. 191-193, 2000.

SIQUEIRA, Belmiro. Do regime de concurso: sua eficiente implantação no S.P.F. Rio de Janeiro: Departamento de Imprensa Nacional, 1950.

TOURINHO, Rita. O concurso público no ordenamento jurídico brasileiro. Rio de Janeiro: Lumen Juris, 2008.

UNIVERSIDADE DE BRASÍLIA. Bases do planejamento estratégico e tático. Brasília, 2007. Disponível em: <http://www.spl.unb.br/planejamento/bases_planejamento_19102007. pdf $>$. Acesso em: 10 nov. 2008.

VERGARA, Sylvia Constant. Projetos e relatórios de pesquisa em administração. 5. ed. São Paulo: Atlas, 2004.

WALZER, Michael. Esferas da justiça: uma defesa do pluralismo e da igualdade. São Paulo: Martins Fontes, 2003. 


\title{
8 ANEXOS
}

\subsection{Lei nº 41 de 04/01/2008 (República Dominicana)}

\author{
Ley No. 41-08 de Función Pública y crea la Secretaría de Estado de Administración \\ Pública.
}

\section{EL CONGRESO NACIONAL En Nombre de la República}

Ley No. 41-08

CONSIDERANDO PRIMERO: Que en la actualidad, el fenómeno de la globalización, la internacionalización de los mercados y los avances tecnológicos, han obligado a que el derecho de la función pública y el régimen de gestión de recursos humanos que le sirve de soporte, se encuentren sometidos a un profundo proceso de revisión y modernización de su contenido, tanto juridico como administrativo;

CONSIDERANDO SEGUNDO: Que, en este sentido, según la Carta Iberoamericana de la Función Pública, respaldada por la XIII Cumbre Iberoamericana de Jefes de Estado y de Gobierno del 2003, el Estado constituye el máximo órgano de articulación de las relaciones sociales, en función de la gobernabilidad, el desarrollo socio-económico sostenible, la reducción de la pobreza y las desigualdades existentes en el ámbito social;

CONSIDERANDO TERCERO: Que los niveles de desarrollo socio-económico de las naciones más avanzadas se vinculan con la puesta en práctica de sistemas de administración pública basados en la profesionalización que resulta de la aplicación de principios meritocráticos;

CONSIDERANDO CUARTO: Que, en consecuencia, la Ley No.14-91, del 20 de mayo de 1991, de Servicio Civil y Carrera Administrativa, elaborada para una época social, económica y políticamente muy diferente de la actual, demanda adecuaciones jurídicas y administrativas, basadas en principios de gestión modernos, ya consagrados en la mayoría de las naciones que cuentan con un derecho de la función pública adecuado;

CONSIDERANDO QUINTO: Que, en el contexto actual la Ley de Servicio Civil y Carrera Administrativa demanda de la incorporación en su contenido de modernos paradigmas jurídicos y administrativos de gestión de los recursos humanos, que propicien la rectificación y adecuación de los conceptos y principios instituidos en su concepción original. Además favorecen que esos paradigmas faciliten la instalación del Estatuto de la función pública de carrera en todo el ámbito de la administración del Estado;

CONSIDERANDO SEXTO: Que dado el avance que se ha operado en la República Dominicana al ser instituidos regímenes de derecho de la función pública de carrera en otros poderes del Estado y en instituciones de la administración pública descentralizada, en cuyos estatutos se advierten notorias discrepancias en los respectivos regímenes éticos y 
disciplinarios, resulta de imperiosa necesidad unificar las disposiciones legislativas concernientes a la conducta de los servidores públicos de la administración pública centralizada y descentralizada;

CONSIDERANDO SÉPTIMO: Que para garantizar la unidad y coherencia del sistema, todo estatuto de carrera de cualquier órgano o entidad de la administración del Estado, antes de ser sometido a la consideración del Congreso Nacional o del Poder Ejecutivo, debe contar con la revisión y opinión técnica de un órgano central que tenga la autoridad política e institucional suficiente para velar por la observación de los principios orientadores del mismo;

CONSIDERANDO OCTAVO: Que las reformas en el ámbito de la macroestructura del Estado se están desarrollando en el marco de acuerdos internacionales;

CONSIDERANDO NOVENO: Que la Ley No.55, del 22 de noviembre de 1965, que crea e integra el Consejo Nacional de Desarrollo.

VISTA: La Ley No.1494, del 2 de agosto de 1947, que instituye la Jurisdicción Contencioso-Administrativa.

VISTA: La Ley Orgánica de Secretarías de Estado, No.4378, del 10 de febrero de 1956, Gaceta Oficial No.7947;

VISTA: La Ley No.14-91, del 20 de mayo de 1991, Gaceta Oficial No.9808, que crea el Servicio Civil y Carrera Administrativa, y su Reglamento de Aplicación No.81-94, del 29 de marzo de 1994, Gaceta Oficial No.9879;

VISTA: La Ley No.120-01, del 20 de julio del 2001, que instituye el Código de Ética del Servidor Público;

VISTA: La Ley No.496-06, del 28 de diciembre del 2006, que crea la Secretaría de Estado de Economía, Planificación y Desarrollo;

VISTA: La Ley No.13-07, del 5 de febrero del 2007, de Control Jurisdiccional de la Actividad Administrativa del Estado, que crea el Tribunal Contencioso Tributario y Administrativo;

VISTO: El Artículo 100 de la Constitución de la República Dominicana.

\section{HA DADO LA SIGUIENTE LEY DE FUNCIÓN PÚBLICA TÍTULO I DISPOSICIONES FUNDAMENTALES}

Artículo 1.- La presente ley tiene por objeto regular las relaciones de trabajo de las 
$-3-$

personas designadas por autoridad competente para desempeñar los cargos presupuestados para la realización de funciones públicas en el Estado, los municipios y las entidades autónomas, en un marco de profesionalización y dignificación laboral de sus servidores.

Párrafo.- Los principios y disposiciones fundamentales de la presente ley serán aplicables a aquellos regímenes de carrera que sean establecidos por otras leyes. Asimismo, esta ley será de aplicación supletoria en todo cuanto no estuviera previsto en dichas leyes.

Artículo 2.- Quedan excluidos de la presente ley:

1. Quienes ocupan cargos por elección popular. Los miembros de la Junta Central Electoral, así como los miembros de la Cámara de Cuentas;

2. Quiénes mantienen relación de empleo con órganos y entidades del Estado bajo el régimen del Código de Trabajo;

3. El personal militar y policial, aunque esté asignado a órganos de seguridad e inteligencia del Estado.

Artículo 3.- El ejercicio de la función pública estará regido por un conjunto ordenado y sistemático de principios fundamentales que constituyen la esencia de su estatuto jurídico, a saber:

1. Mérito personal: Tanto el ingreso a la función pública de carrera como su ascenso dentro de ésta debe basarse en el mérito personal del ciudadano, demostrado en concursos internos y externos, la evaluación de su desempeño y otros instrumentos de calificación;

2. Igualdad de acceso a la función pública: Derecho universal de acceder a los cargos y a las oportunidades de la función pública sin otro criterio que el mérito personal y sin discriminación de género, discapacidad o de otra índole;

3. Estabilidad en los cargos de carrera: Permanencia del servidor público de carrera, garantizada por el Estado, siempre que su desempeño se ajuste a la eficiencia y a los requerimientos éticos y disciplinarios del sistema;

4. Equidad retributiva: Prescribe el principio universal, que a trabajo igual, en idénticas condiciones de capacidad, desempeño o antigüedad, corresponde siempre igual remuneración, cualesquiera que sean las personas que lo realicen;

5. Flexibilidad organizacional: Potestad reconocida del Estado empleador de variar las condiciones de trabajo por interés institucional;

6. Irrenunciabilidad: Los derechos y prenrogativas que la presente ley reconoce a los servidores públicos son irrenunciables; 
7. Tutela Judicial: Reconoce la facultad del servidor público lesionado de recurrir ante la jurisdicción contencioso-administrativa en demanda de protección, como parte de los derechos consagrados segín lo dispuesto por la presente ley.

Artículo 4.- A los fines y efectos de la presente ley, deberá entenderse por:

1. Administración del Estado: Conjunto de órganos y entidades pertenecientes a los Poderes Legislativo, Ejecutivo y Judicial, incluyendo las entidades municipales, así como los órganos constitucionales como la Junta Central Electoral y la Cámara de Cuentas;

2. Administración Pública Central: Núcleo central de la administración del Estado integrado, además, por los órganos del Poder Ejecutivo con programación anual y consignación de fondos que están contenidas en la Ley de Gastos Públicos, cuyos titulares dependen directa y jerárquicamente del Presidente de la República;

3. Administración Pública Descentralizada: Entidades dotadas de autonomía administrativa y financiera, con personalidad jurídica diferente a la del Estado. Estas entidades están adscritas a la Secretaría de Estado afin con sus cometidos institucionales, y el titular de la cartera ejerce sobre las mismas una tutela administrativa y un poder de supervigilancia;

4. Servidor Público: Persona que ejerce un cargo permanente de la función pública, designado por autoridad competente;

5. Formación: Proceso de instrucción, enseñanza o educación que forma a los servidores públicos activos de la administración del Estado en ramas especializadas de la gestión pública;

6. Capacitación: Conjunto de procesos organizados, tanto formales como informales, dirigidos a complementar la educación técnica o profesional del servidor público, con la finalidad de desarrollar sus aptitudes, habilidades y destrezas y lograr un cambio de actitud en su desarrollo personal integral, con miras al eficaz ejercicio de sus funciones, al cumplimiento de la misión y visión institucionales y a la prestación de mejores servicios a la población;

7. Carrera Administrativa General: Sistema cuya finalidad es promover la eficiencia y eficacia de la gestión pública para cumplir los fines del Estado, garantizando la profesionalidad, la estabilidad y el desarrollo de los servidores públicos;

8. Carreras Administrativas Especiales: Sistemas de función pública profesional diseñados a partir del sistema de carrera administrativa general y de las características específicas de determinados ámbitos públicos;

9. Estatuto de la Función Pública: Conjunto de las disposiciones legales reguladoras de 
$-5-$

las relaciones de trabajo entre el Estado y el servidor público;

10. Gestión Institucional: Conjunto de acciones de los órganos y entidades de la administración del Estado con el fin de garantizar su misión fundamentada en los principios de eficiencia, eficacia, transparencia, honestidad, celeridad, participación, rendición de cuentas y responsabilidad en el ejercicio de la función pública;

11. Gobierno Electrónico: Gestión que incorpora de manera intensiva la tecnología de la información y la comunicación a la administración pública;

12. Tutela Administrativa: Conjunto de facultades de control y supervigilancia otorgadas a las Secretarías de Estado para velar por la orientación, eficacia, eficiencia y legalidad de la gestión de las entidades descentralizadas, cuyos objetivos programáticos les son afines.

Artículo 5.- En la Administración Pública Central, en las entidades autónomas, los municipios, y en los órganos constitucionales que corresponda, serán implantadas las normas y los procedimientos de la carrera administrativa general, en la medida en que la Secretaría de Estado de Administración Pública haya realizado los estudios técnicos necesarios e implantado los sistemas y subsistemas de gestión de recursos humanos correspondientes.

Artículo 6.- El Presidente de la República podrá crear carreras administrativas especiales en aquellos órganos de la Administración Pública Central y en las entidades descentralizadas, previo estudio y opinión favorable de la Secretaría de Estado de Administración Pública.

Párrafo I.- Las carreras Docente, Diplomática y Consular, Sanitaria y la del Ministerio Público se consideran carreras administrativas especiales.

Párrafo II.- Los reglamentos complementarios necesarios para configurar y desarrollar las carreras administrativas especiales deberán ser elaborados por su órgano directivo superior y luego sometidos, con la opinión favorable de la Secretaría de Estado de Administración Pública, a la aprobación del Presidente de la República.

\section{TÍTULO II DIRECCIÓN Y ADMINISTRACIÓN DE LA FUNCIÓN PÚBLICA \\ CAPÍTULO I \\ DE LA SECRETARÍA DE ESTADO DE ADMINISTRACIÓN PÚBLICA}

Artículo 7.- Se crea la Secretaría de Estado de Administración Pública como órgano rector del empleo público y de los distintos sistemas y regímenes previstos por la presente ley, del fortalecimiento institucional de la Administración Pública, del desarrollo del gobierno electrónico y de los procesos de evaluación de la gestión institucional. 
Artículo 8.- Corresponderá a la Secretaría de Estado de Administración Pública, las atribuciones siguientes:

1. Propiciar y garantizar el más alto nivel de efectividad, calidad y eficiencia de la función pública del Estado, y asignar el respeto de los derechos de los servicios públicos en el marco de la presente ley;

2. De conformidad con la presente ley y con las orientaciones que dicte el Presidente de la República, diseñar, ejecutar y evaluar las políticas, planes y estrategias nacionales en materia de empleo público, en el marco de los planes nacionales de desarrollo y de los recursos presupuestarios disponibles;

3. Velar por el fiel cumplimiento de las disposiciones previstas en la presente ley;

4. Elaborar y proponer al Presidente de la República los reglamentos complementarios a la presente ley, en especial los que desarrollen la carrera administrativa general. Así como estudiar y opinar sobre los proyectos de reglamentos que desarrollen las carreras administrativas especiales;

5. Emitir, con carácter obligatorio y vinculante, dictámenes interpretativos sobre la aplicación de la presente ley y sus respectivos reglamentos;

6. Dirigir los distintos procesos de gestión del recurso humano al servicio de la Administración Pública Central y Descentralizada que le correspondan de conformidad con la presente ley y sus reglamentos complementarios. Para ello dictará las instrucciones que sean pertinentes a las distintas oficinas de personal de los órganos y entidades de la Administración Pública, y supervisará su cumplimiento;

7. Coordinar, supervisar y evaluar la implantación de los distintos sistemas de carrera administrativa que prevé la presente ley, proveyendo la debida asistencia técnica a los distintos órganos y entidades de la Administración Pública;

8. Aprobar la estructura de cargos de la Administración Pública, previo a su inclusión en el anteproyecto de presupuesto anual;

9. Elaborar y actualizar anualmente el sistema retributivo del personal de la Administración Pública Central y Descentralizada, en coordinación con la Secretaría de Estado de Economía, Planificación y Desarrollo y la Dirección General de Presupuesto;

10. Establecer y mantener actualizado un registro central de personal, mediante un sistema de información automatizado;

11. Identificar las necesidades de fortalecimiento institucional de la Administración 
$-7-$

Pública y, conforme con las orientaciones que dicte el Presidente de la República, diseñar, ejecutar y evaluar las políticas, planes y estrategias nacionales en la materia;

12. Evaluar y proponer las reformas de las estructuras orgánica y funcional de la administración pública. Asimismo, revisar y aprobar los manuales de procedimiento y de organización y organigramas que eleven para su consideración los órganos y entidades de la administración pública;

13. Diseñar, programar e impulsar actividades permanentes de simplificación de trámites, de flexibilización organizativa, de eliminación de duplicación de funciones y de promoción de coordinación interorgánica e interadministrativa;

14. Diseñar, ejecutar y evaluar políticas, planes y estrategias de automatización de sistemas de información y procesos mediante el desarrollo e implantación de tecnologías de informática y telemática;

15. Diseñar, ejecutar y evaluar políticas, planes y estrategias para la implantación de metodologías, técnicas y sistemas de evaluación de la gestión institucional. Para ello promoverá y regulará la realización de evaluaciones periódicas del desempeño institucional que impulsen una cultura de transparencia, y responsabilización de la gestión pública;

16. Todas aquéllas necesarias para el mejor cumplimiento de la presente ley;

17. Formular los criterios generales para el diseño de las actividades de formación y capacitación indispensables para la inducción en el ingreso de los servidores públicos, y para la promoción de los funcionarios de carrera.

Artículo 9.- La Secretaria de Estado de Administración Pública se estructurará, atendiendo sus áreas de competencia y funciones, en tres (3) subsecretarías de Estado:

1. Función Pública;

2. Fortalecimiento Institucional;

3. Evaluación del Desempeño Institucional.

El Reglamento Orgánico-Funcional de la Secretaría de Estado de Administración Pública determinará las funciones específicas y la estructura interna de las subsecretarías y demás unidades orgánicas necesarias para su eficaz funcionamiento.

CAPÍTULO II

DEL INSTITUTO NACIONAL DE ADMINISTRACIÓN PÚBLICA 
$-8-$

Artículo 10.- El Instituto Nacional de Administración Pública, tendrá a su cargo la ejecución, coordinación, seguimiento y evaluación de los procesos de inducción, formación y capacitación del personal de los órganos y entidades sujetos a la presente ley, de conformidad con las políticas, planes, estrategias y programas que apruebe la Secretaría de Estado de Administración Pública. Asimismo, realizará los estudios e investigaciones para la mejora del funcionamiento de la administración pública que le sean encomendados.

Párrafo.- El Instituto Nacional de Administración Pública será un órgano desconcentrado de la Secretaría de Estado de la Administración Pública. En la Ley de Gastos Públicos de cada año se consignarán los recursos provenientes del presupuesto nacional necesarios para el cumplimiento de sus funciones.

Artículo 11.- El Instituto Nacional de Administración Pública tendrá las funciones y facultades siguientes:

1. Coadyuvar en la identificación de necesidades de formación y capacitación del personal de los órganos y entidades de la administración pública;

2. Diseñar y proponer a la Secretaría de Estado de Administración Pública políticas, planes y estrategias de formación y capacitación;

3. Ejecutar, coordinar, monitorear y evaluar las actividades de formación y capacitación, aprobados por la Secretaría de Estado de Administración Pública;

4. Acreditar los contenidos de los cursos de formación y capacitación a ser realizados por los órganos y entidades de la administración pública de manera directa, o a través de entidades académicas públicas o privadas. Asimismo, asistirá a los órganos y entidades de la administración pública para la mejor ejecución de sus programas de capacitación, de conformidad con las orientaciones aprobadas por la Secretaría de Estado de Administración Pública;

5. Formular los criterios generales para el diseño de las actividades de formación y capacitación indispensables para la inducción en el ingreso de los servidores públicos, y para la promoción de los funcionarios de carrera;

6. Propiciar convenios de cooperación técnica con organismos nacionales, extranjeros o internacionales, públicos o privados, y en especial establecer programas de cooperación horizontal con organismos gubernamentales de formación y capacitación de otros paises.

7. Propiciar la celebración de convenios con la Secretaria de Estado de Educación (SEE) y otras secretarías a los fines del mejor cumplimiento de sus respectivas misiones;

8. Suscribir convenios de cooperación técnica con organismos nacionales, extranjeros o internacionales, públicos o privados, y en especial establecer programas de 
$-9-$

cooperación horizontal con organismos gubernamentales de formación y capacitación de otros países;

9. Celebrar convenios con la Secretaría de Estado de Educación a los fines del mejor cumplimiento de sus respectivas misiones;

10. Todas aquellas funciones que le sean conferidas en los reglamentos complementarios de la presente ley.

Artículo 12.- El Director del Instituto Nacional de Administración Pública será designado por el Presidente de la República y tendrá rango y jerarquía de Director General. Le corresponde la representación y dirección del mismo de conformidad con la autonomía presupuestaria y administrativa otorgada por la presente ley.

Párrafo.- En el cumplimiento de las funciones de formación y capacitación, el Director contará con la asistencia de un Consejo Académico, cuya integración y competencias se regularán en el reglamento de la presente ley.

\section{CAPITULO III \\ DE LAS OFICINAS DE RECURSOS HUMANOS}

Artículo 13.- En los órganos y entidades de la administración pública sometidos a la presente ley, habrá una Oficina de Recursos Humanos, cuyas atribuciones serán las siguientes:

1. Instruir los expedientes en caso de hechos que pudieren dar lugar a la aplicación de las sanciones previstas en la presente ley;

2. Actuar como enlace entre el órgano o entidad respectiva y la Secretaría de Estado de Administración Pública a los fines de la presente ley;

3. Ejecutar las decisiones que dicten las autoridades encargadas de la gestión de la función pública y aplicar las normas y los procedimientos que en materia de administración de recursos humanos señale la presente ley y sus reglamentos complementarios;

4. De conformidad con la presente ley, sus reglamentos complementarios, y las normas y directrices que emanen de la Secretaria de Estado de Administración Pública, elaborar el Plan de Recursos Humanos, dirigir, coordinar, evaluar, controlar su ejecución y remitir a la Secretaría de Estado de Administración Pública los informes relacionados con ésta, así como cualquier otra información que le fuere solicitada;

5. Coadyuvar en la ejecución de los programas de inducción, formación y capacitación del personal, de conformidad con las políticas que establezca la Secretaría de Estado de Administración Pública; 
6. Participar en los procesos para la evaluación del personal;

7. Colaborar con la organización y realización de los concursos de oposición que se requieran para el ingreso o ascenso de los funcionarios de carrera;

8. Proponer ante la Secretaría de Estado de Administración Pública los movimientos de personal a que hubiere lugar, a los fines de su aprobación;

9. Las demás que se establezcan en la presente ley y sus reglamentos complementarios.

Artículo 14.- Las oficinas de recursos humanos estarán bajo la dependencia técnica de la Secretaría de Estado de Administración Pública y los cargos diseñados para sus titulares son de carrera administrativa.

\section{CAPÍTULO IV \\ DE LAS COMISIONES DE PERSONAL}

Artículo 15.- En cada órgano y entidad pública sujeto a la presente ley se constituirá adhoc una Comisión de Personal, con atribuciones de conciliación en su ámbito de competencia, sin menoscabo de los recursos administrativos y contencioso-administrativos que puedan ejercer los servidores públicos. A tales efectos conocerá y procesará, de conformidad con los reglamentos complementarios de la presente ley, las peticiones o reclamos que presenten los servidores públicos, sean o no de carrera.

Artículo 16.- La Comisión de Personal estará integrada por:

1. Un representante de la Secretaría de Estado de la Función Pública, quien la presidirá;

2. Un representante de la autoridad máxima del órgano o entidad administrativa donde sea generado el conflicto;

3. El empleado interesado o su representante.

Artículo 17.- Los acuerdos de conciliación de las Comisiones de Personal se decidirán por unanimidad, y serán de obligatorio cumplimiento por las partes. En caso de incumplimiento de lo pactado, podrá solicitarse su ejecución forzosa a la jurisdicción contenciosa administrativa.

\section{TÍTULO III \\ CATEGORÍAS DE SERVIDORES PÚBLICOS}

Artículo 18.- Por la naturaleza de su relación de empleo, los servidores públicos al servicio de los órganos y entidades de la administración pública, se clasifican en: 
$-11-$

1. Funcionarios o servidores públicos de libre nombramiento y remoción;

2. Funcionarios o servidores públicos de carrera;

3. Funcionarios o servidores públicos de estatuto simplificado;

4. Empleados temporales.

Artículo 19.- Son funcionarios o servidores públicos de libre nombramiento y remoción quienes ocupan cargos de alto nivel.

Artículo 20.- Los cargos de alto nivel son los siguientes:

1. Secretarios de Estado, Consultor Jurídico del Poder Ejecutivo, Contralor General de la República, y Procurador General de la República;

2. Subsecretarios de Estado, titulares de organismos autónomos y descentralizados del Estado y otros de jerarquía similar o cercana del Presidente de la República y de los altos ejecutivos de las instituciones públicas;

3. Directores Nacionales y Generales y Subdirectores;

4. Administradores, Subadministradores, Jefes y Subjefes, Gerentes y Subgerentes, y otros de naturaleza y jerarquía similares;

5. Gobernadores Civiles y otros representantes del Poder Ejecutivo en el Distrito Nacional y en las provincias.

Párrafo.- El Presidente de la República podrá disponer que determinados cargos de nivel inferior al de Subsecretario de Estado sean seleccionados para integrar una carrera directiva pública, bajo las condiciones que sean reguladas por la presente ley.

Artículo 21.- Los cargos de confianza son los de secretarios, ayudantes, asesores y asistentes de alta confianza de las máximas autoridades ejecutivas del sector público, salvo aquellos cuya forma de designación esté prevista por ley.

Párrafo I- Son funcionarios públicos de confianza quienes desempeñan los puestos expresamente calificados por sus funciones de asesoramiento especial o la asistencia directa a los funcionarios de alto nivel. No serán acreedores de los derechos propios del personal de carrera.

Párrafo II.- El personal de confianza será libremente nombrado y removido, cumpliendo meramente los requisitos generales de ingreso a la función pública, a propuesta de la autoridad a la que presten su servicio. 
Párrafo III.- La Secretaria de Estado de Administración Pública autorizará en cada caso, y después del análisis correspondiente, la creación de cargos para el asesoramiento especial o la asistencia directa a los funcionarios de alto nivel. La creación de estos cargos estará sujeta a la existencia de disponibilidad presupuestaria.

Artículo 22.- Los funcionarios públicos de carrera que sean nombrados en cargos de alto nivel o de confianza volverán a su cargo de origen cuando sean removidos. Asimismo, el tiempo desempeñado en cargos de alto nivel o de confianza se computará a los fines de su antigüedad en la carrera administrativa.

Párrafo.- Todo funcionario que sea designado para ocupar un cargo de alto nivel o electivo, deberá tener una licencia sin disfrute de sueldo en el cargo de carrera administrativa.

Artículo 23.- Es funcionario o servidor público de carrera administrativa quien, habiendo concursado públicamente y superado las correspondientes pruebas e instrumentos de evaluación, de conformidad con la presente ley y sus reglamentos complementarios, ha sido nombrado para desempeñar un cargo de carácter permanente clasificado de carrera y con previsión presupuestaria.

Párrafo.- Los funcionarios públicos de carrera sólo perderán dicha condición en los casos que expresamente determina la presente ley, previo cumplimiento del procedimiento administrativo correspondiente y formalizado mediante acto administrativo. El cese contrario a derecho se saldará con la reposición del servidor público de carrera en el cargo que venía desempeñando, y el abono de los salarios dejados de percibir. La Secretaría de Estado de Administración Pública deberá instar al órgano correspondiente el procedimiento que permita deslindar las responsabilidades por la comisión de dicho cese.

Artículo 24.- Es funcionario o servidor público de estatuto simplificado quien resulte seleccionado para desempeñar tareas de servicios generales y ofícios diversos, en actividades tales como:

1. Mantenimiento, conservación y servicio de edificios, equipos e instalaciones; vigilancia, custodia, portería y otros análogos;

2. Producción de bienes y prestación de servicios que no sean propiamente administrativos $\mathrm{y}$, en general, todos los que impliquen el ejercicio de un oficio específico;

3. Las que no puedan ser incluidas en cargos o puestos de trabajo de función pública.

Párrafo.- Este personal no disfruta de derecho regulado de estabilidad en el empleo, ni de otros propios de los funcionarios de carrera administrativa, pero sí del resto de derechos y obligaciones del servidor público previsto en la presente ley. 
$-13-$

Artículo 25. Podrán nombrarse empleados temporales en aquellos cargos de carrera administrativa de naturaleza permanente que se encuentren vacantes y no puedan proveerse de forma inmediata por personal de carrera. Asimismo en los que exista un titular con derecho a reserva, que por cualquier causa prevista no pueda desempeñarlo.

Párrafo I.- El personal temporal deberá reunir los requisitos legales y reglamentarios para desempeñar el puesto y se regirá por los preceptos de la presente ley que le sean aplicables. No obstante, su nombramiento, sea cual fuere el tiempo que se prolongue, no le otorgará derecho alguno para su ingreso en la carrera administrativa.

Párrafo II.- El nombramiento de personal temporal se extenderá por un plazo máximo de hasta seis (6) meses, durante el cual deberá procederse a la cobertura legalmente establecida. Si transcurrido dicho plazo el puesto no ha sido objeto de convocatoria para su provisión no podrá seguir siendo desempeñado.

Párrafo III.- Son causas de cese del personal temporal la desaparición de las circunstancias que dieron lugar a su nombramiento, la provisión del puesto por personal de carrera, el vencimiento del plazo, y las demás que determinan la pérdida de la condición de empleado público.

\section{TÍTULO IV \\ DE LA CLASIFICACIÓN, VALORACIÓN Y RETRIBUCIÓN DE PUESTOS DE TRABAJO}

Artículo 26.- El sistema de clasificación de puestos de trabajo constituye el instrumento primordial de planificación de los recursos humanos de la administración pública, y establece el contenido esencial de los cargos, a efectos de la selección de personal, de la provisión de puestos y de la determinación de retribuciones. Para lo dispuesto en la presente ley, puesto de trabajo y cargo son téminos equivalentes.

Artículo 27.- La creación, clasificación, supresión o modificación de los puestos de trabajo será efectuada por la Secretaría de Estado de Administración Pública, incorporándose a la correspondiente relación de puestos de trabajo y se expresará mediante la elaboración de manuales de cargos, de conformidad con los reglamentos complementarios de la presente ley.

Párrafo.- La clasificación contendrá, además de los elementos que deben reflejarse en las relaciones de cargos, la descripción general y suscrita de las funciones o tareas del puesto y cualquiera otra característica relevante para su desempeño, tendiendo a la polivalencia en los cometidos y la flexibilidad en la gestión de personal, de conformidad con las previsiones de la presente ley y sus reglamentos complementarios.

Artículo 28.- Una vez clasificados los puestos de trabajo, se elaborarán las relaciones de cargos, constituidas por el listado ordenado de dichos puestos por cada órgano y entidad de la administración pública de conformidad con la reglamentación complementaria de la presente ley. 
Artículo 29.- El titular de cada órgano y entidad de la Administración Pública deberá realizar la propuesta de creación, clasificación, modificación o supresión de cargos atendiendo a lo establecido en este título y a los lineamientos de la Secretaría de Estado de Administración Pública.

Artículo 30.- Los servidores públicos tendrán derecho a percibir las retribuciones que se establezcan de conformidad con la presente ley y la reglamentación complementaria.

Párrafo.- No podrá disponerse pago alguno por el desempeño de un cargo que no estuviera debidamente clasificado e incluido en el presupuesto de gastos y aprobado en la estructura de cargos del órgano o entidad respectiva.

Artículo 31.- La Secretaría de Estado de Administración Pública diseñará las propuestas de políticas salariales del sector público y las elevará a través del Presidente de la República al Consejo de Gobierno para su consideración.

Párrafo.- En ejecución de las orientaciones que dicte el Presidente de la República, la Secretaría de Estado de Administración Pública elaborará el sistema salarial y los respectivos análisis de salarios, de conformidad con la presente ley, así como la reglamentación complementaria.

\section{TÍTULO V \\ DEL INGRESO AL SERVICIO PÚBLICO}

Artículo 32.- Toda persona tendrá derecho de acceder al servicio público en condiciones de igualdad, sin más requisitos que los establecidos de conformidad con lo previsto en la presente ley y su reglamentación complementaria.

Artículo 33.- Las condiciones generales de ingreso al servicio público son las siguientes:

1. Ser dominicano;

2. Estar en pleno goce de los derechos civiles y políticos;

3. Estar en buenas condiciones de salud física y mental para desempeñar el cargo;

4. Demostrar capacidad o idoneidad para el buen desempeño del cargo mediante los sistemas de selección que se establezcan según la clase de cargo a ocupar;

5. No estar incurso en el régimen de incompatibilidades;

6. No encontrarse inhabilitado:

a) por destitución de un cargo público debido a la comisión de una falta de tercer grado conforme a lo establecido en el régimen ético y disciplinario 
$-15-$

previsto en la presente ley;

b) por haber sido sancionado por sentencia judicial de conformidad con la legislación penal vigente;

c) por haber intentado ingresar o haber ingresado al servicio público mediante actuaciones fraudulentas.

7. Tener la edad constitucional o legalmente exigida;

8. Ser nombrado o contratado por autoridad competente, juramentarse en los casos previstos en el ordenamiento jurídico y tomar posesión del cargo conforme a lo dispuesto por la Constitución y las leyes de la República.

Párrafo I- Todo nombramiento o contratación efectuado sin el cumplimiento de lo dispuesto en el presente artículo será nulo sin perjuicio del tiempo que hubiera transcurrido, lo cual no afectará la validez de los actos y actividades efectuados por la persona.

Párrafo II.- Asimismo, la Secretaría de Estado de Administración Pública promoverá ante la autoridad competente a que proceda en consecuencia, al momento en que conociera del incumplimiento de los requisitos establecidos en el presente artículo.

Párrafo III.- Deberá precederse con el procedimiento de rigor para el deslinde de las responsabilidades de los funcionarios intervinientes en ese incumplimiento.

Artículo 34.- La selección y provisión de empleados públicos contratados se realizará mediante el procedimiento que establezca la reglamentación complementaria de la presente ley.

Artículo 35.- Los empleados de estatuto simplificado contratados deberán superar un período probatorio de hasta seis (6) meses. La falta de capacidad comprobada en cualquier momento del período de prueba, será causa de extinción de la contratación. El superior inmediato deberá motivar esta circunstancia e informar a la Oficina de Recursos Humanos para que realice el trámite oportuno.

Artículo 36.- Son autoridades competentes para efectuar nombramientos y contrataciones en el ámbito del Poder Ejecutivo, el Presidente de la República o el titular de la entidad descentralizada con facultad expresamente asignada por disposición legal. En el resto de los Poderes del Estado, órganos constitucionales y entidades municipales, se efectuará conforme a lo que determine la Constitución y las leyes de la República.

Artículo 37.- Para el ingreso a las Carreras Administrativa General y Especiales, los candidatos deberán acreditar, además de los requisitos generales de ingreso al servicio público, los siguientes: 
$-16-$

1. Llenar los requisitos mínimos señalados para el cargo o clase de cargos;

2. Tener edad inferior a los cincuenta y cinco (55) años y no ser acreedor del beneficio de jubilación o pensión;

3. Demostrar mediante concurso de libre competición que posee la idoneidad que demanda el cargo o clase de cargos;

4. Superar el ciclo de inducción obligatorio, a cargo del Instituto Nacional de Administración Pública;

5. Superar el período de prueba de hasta doce (12) meses, de conformidad con la reglamentación complementaria de la presente ley y los manuales de cargos.

Artículo 38.- Las vacantes que se produzcan en los cargos de carrera serán cubiertas en primer lugar mediante concursos internos para ascensos organizados de todo funcionario público, y en caso de declararse desiertos, se convocará a concursos externos. Corresponderá a la Secretaría de Estado de Administración Pública la organización de dichos concursos, tarea que deberá coordinar con las Oficinas de Recursos Humanos de los órganos o entidades a los que pertenezcan los cargos vacantes. La reglamentación complementaria de la presente ley regulará los procesos de convocatoria y realización de los concursos internos y extemos antes señalados.

Artículo 39.- La convocatoria de todo concurso interno o externo de libre competición, deberá ser ampliamente publicitado, con preferencia en la jurisdicción del cargo y contener de forma clara y precisa las menciones previstas en el reglamento de la presente ley.

Artículo 40.- Las pruebas y los instrumentos de evaluación a ser aplicados a los aspirantes estarán dirigidos a identificar de manera objetiva los conocimientos, aptitudes, habilidades, destrezas y el grado de adaptación de los candidatos en relación con la naturaleza de los cargos a cubrir. Para ello la Secretaría de Estado de Administración Pública determinará previamente los criterios, métodos y técnicas de evaluación.

Artículo 4l.- La constitución, integración, designación y funcionamiento de los jurados de los concursos de oposición serán regulados por la reglamentación complementaria de la presente ley.

Artículo 42.- La Secretaría de Estado de Administración Pública establecerá la puntuación mínima para la superación de las pruebas de los concursos de oposición. En el caso de que en un concurso de oposición interno o externo quienes superen las pruebas sean un número mayor al número de cargos vacantes, quienes obtengan las mejores puntuaciones se considerarán con derecho a ser titulares de dichos cargos. Los demás aspirantes que alcancen la puntuación establecida serán incluidos en el Registro de Elegibles para la cobertura de puestos vacantes de la misma naturaleza.

Artículo 43.- Quienes conformen el Registro de Elegibles permanecerán en éste por un 
$-17-$

máximo de dieciocho (18) meses contados a partir de la fecha en la que se hubiere aprobado su selección. En caso que el o los titulares designados en los cargos concursados no hubieren tomado posesión de los mismos dentro del plazo previsto, o se hubiere extinguido su relación de empleo por cualquier causa prevista en la presente ley, deberá designarse el elegible que siga en el orden de mérito resultante en el concurso de oposición correspondiente. De la misma manera se procederá en caso de que durante el término antes fijado la administración necesitare cubrir otros cargos vacantes de idénticas características.

Artículo 44.- Quienes hayan superado el proceso selectivo serán nombrados funcionarios de carrera en período de prueba. Este nombramiento provisional corresponderá al Secretario de Estado de Administración Pública o al titular del órgano que en el momento ostente la máxima autoridad en la gestión del personal de la administración pública, o autoridad superior en la gestión del personal en los órganos autónomos o descentralizados y en los municipios.

\section{TÍTULO VI \\ DEL DESARROLLO, EVALUACIÓN DEL DESEMPEÑO Y PROMOCIÓN}

Artículo 45.- Se establece la formación y capacitación como fundamento del desarrollo y promoción de los servidores públicos, y del incremento de la capacidad de gestión de la administración pública. A tal efecto, se considera de carácter obligatorio la participación de los servidores públicos en los programas de inducción, formación y capacitación que prevea la Secretaria de Estado de Administración Pública a través del Instituto Nacional de Administración Pública, cuyos resultados determinarán la permanencia, promoción y ascenso de los funcionarios públicos de carrera, de conformidad con la presente ley y sus reglamentos complementarios.

Artículo 46.- El desempeño de los funcionarios públicos de carrera será evaluado periódicamente, de manera objetiva e imparcial.

La evaluación del desempeño del funcionario público de carrera, tendrá por finalidad:

1. Determinar la calidad de su trabajo y su posible mejora;

2. Determinar sus necesidades de formación y capacitación y prever su desarrollo;

3. Otorgar incentivos económicos, académicos y morales;

4. Determinar su permanencia y promoción en la carrera.

Artículo 47.- La evaluación del desempeño de los funcionarios públicos se efectuará a través de las técnicas, metodologías, procedimientos e instrumentos que se determinen en la reglamentación complementaria de la presente ley.

Artículo 48.- Los funcionarios públicos de carrera cuyo desempeño haya sido calificado de insatisfactorio, mediante el proceso de evaluación, deberán someterse a un programa 
$-18-$

especial de capacitación. En los casos en que el funcionario público de carrera no culmine o apruebe el programa especial de capacitación, o que en el siguiente proceso de evaluación su desempeño sea nuevamente calificado de insatisfactorio, será destituido de su cargo.

Artículo 49.- La promoción de los funcionarios públicos dentro de la carrera administrativa se fundamentará en el mérito personal, y podrá efectuarse mediante el avance del funcionario dentro de un mismo cargo o su ascenso a un cargo distinto o superior. La reglamentación complementaria de la presente ley establecerá y regulará los mecanismos y procedimientos de promoción correspondientes, garantizando su carácter objetivo e imparcial.

Artículo 50.- Por necesidades del servicio, los funcionarios públicos de carrera podrán ser asignados para realizar funciones en comisión de servicio en otro órgano o entidad distinto al que se encuentra adscrito. Igualmente podrán ocupar cargos vacantes en otros órganos o entidades. En este último caso, el funcionario público en comisión de servicio cobrará las remuneraciones correspondientes al cargo que ejerza y conservará la titularidad de su cargo originario.

\section{TÍTULO VII \\ DE LAS CONDICIONES DE TRABAJO}

Artículo 51.- La jornada semanal de trabajo no será inferior a treinta (30) horas ni superior a cuarenta (40) horas semanales, salvo lo que dispongan los titulares de los órganos y entidades cuando en atención a situaciones especiales e intereses de la administración, se demande una jornada superior.

Artículo 52.- Los horarios diarios de trabajo en los órganos y entidades de la administración pública serán dispuestos por sus respectivos titulares e informados a la Secretaría de Estado de Administración Pública.

Artículo 53.- Los servidores públicos de la administración del Estado tienen derecho, después de un trabajo continuo de un (1) año, al disfrute de vacaciones anuales remuneradas, de conformidad con lo siguiente:

1. Durante un mínimo de un (1) año y hasta un máximo de cinco (5) años, tendrán derecho a quince (15) días laborables de vacaciones, dentro del año calendario correspondiente;

2. Los servidores públicos que hayan trabajado más de cinco (5) años y hasta diez (10) años tendrán derecho a veinte (20) días laborables de vacaciones;

3. Los servidores que hayan laborado más de diez (10) años y hasta quince (15) años tendrán derecho a veinticinco (25) días laborables de vacaciones;

4. Los empleados y funcionarios que hayan trabajado más de quince (15) años tendrán derecho a treinta (30) días laborables de vacaciones. 
$-19-$

Artículo 54.- Los servidores públicos que, en un año calendario determinado, no pudieren disfrutar de sus vacaciones por razones atendibles, podrán acumularlas y disfrutarlas en adición a las del año inmediatamente siguiente. Sólo serán acumulables las vacaciones de dos años consecutivos.

Los superiores inmediatos dispondrán lo conveniente para que los servidores públicos de su dependencia se turnen al tomar las vacaciones, de modo que el servicio no sufra demora, ni perjuicio.

Se prohibe la renuncia al disfrute de las vacaciones con el propósito de que éstas sean compensadas con emolumentos especiales a favor del beneficiario, y ninguna autoridad podrá disponer su pago.

Artículo 55.- Los empleados y funcionarios de los órganos de la administración del Estado que hayan servido un mínimo de seis (6) meses dentro del año calendario correspondiente, tendrán derecho a recibir el pago de sus vacaciones, en caso de ser desvinculados del servicio, en la proporción que les corresponda.

Artículo 56.- A los fines de la presente ley se considerará como licencia toda dispensa de asistir al trabajo que exceda los tres (3) días, otorgada por autoridad competente de conformidad con las previsiones reglamentarias. Se considera como permiso la dispensa para asistir al trabajo que no exceda los tres (3) días, aplicables en los casos que determine el reglamento.

Artículo 57.- Las licencias que las autoridades competentes pueden conceder a los servidores públicos sujetos a la presente ley, son las siguientes:

1. Licencia ordinaria sin sueldo;

2. Licencia por enfermedad, con disfrute de sueldo;

3. Licencia por matrimonio, con disfrute de sueldo;

4. Licencia para servidores públicos de carrera, con el objetivo de realizar estudios, investigaciones y observaciones que se relacionen directamente con el ejercicio de las funciones propias de la institución, con disfrute de sueldo;

5. Licencias especiales, con o sin disfrute de sueldo;

6. Licencias por causa de fuerza mayor, con disfrute de sueldo;

7. Licencias pre y post-natal, con disfrute de sueldo;

8. Licencias compensatorias, con disfrute de sueldo. 
$-20-$

La reglamentación complementaria regulará todo lo concerniente a las licencias y los permisos.

\section{TÍTULO VIII \\ DE LOS DERECHOS GENERALES Y ESPECIALES \\ CAPÍTULO I \\ DE LOS DERECHOS INDIVIDUALES}

Artículo 58.- Son derechos de todos los servidores públicos sujetos a la presente ley, los siguientes:

1. Percibir una remuneración por sus servicios de conformidad con el régimen retributivo establecido por la presente ley y su reglamentación, así como los demás beneficios y compensaciones de carácter económico establecido en su favor;

2. Recibir inducción, formación y capacitación adecuadas, a fin de mejorar el desempeño de sus funciones;

3. Participar y beneficiarse de los programas y actividades de bienestar social que se establezcan;

4. Recibir el sueldo anual número trece (13), el cual será equivalente a la duodécima parte de los salarios de un año, cuando el servidor público haya laborado un mínimo de tres (3) meses en el año calendario en curso;

5. Disfrutar de las licencias y permisos establecidos en la presente ley;

6. Recibir el beneficio de las prestaciones sociales, jubilaciones y pensiones que les correspondan;

7. Recibir un tratamiento justo en las relaciones interpersonales con compañeros de trabajo, superiores y subalternos, derivadas de las relaciones de trabajo;

8. Tener garantizadas condiciones y medio ambiente de trabajo sanos;

9. Los demás derechos que legalmente les correspondan contemplados en la presente ley.

Artículo 59.- En adición a los derechos generales de los servidores públicos, son derechos especiales de los funcionarios de carrera, los siguientes:

1. A la titularidad de un cargo permanente de la administración pública clasificado como de carrera; 
2. De estabilidad en la carrera administrativa bajo las condiciones previstas por la presente ley;

3. Ser restituido en su cargo cuando su cese resulte contrario a las causas consignadas expresamente en la presente ley y recibir los salarios dejados de percibir entre la fecha de la desvinculación y la fecha de la reposición, sin perjuicio de las indemnizaciones que la jurisdicción contencioso administrativa pueda considerar. Es decisión del empleado aceptar la restitución en el mismo destino, en caso de no aceptarla la institución deberá reubicarlo en otro destino;

4. A la promoción dentro de la carrera administrativa;

5. Ejercer los demás derechos que con carácter especial se establezcan legal o reglamentariamente en su favor, por su condición de servidor de carrera;

6. Ser ascendidos por sus méritos, a cargos de mayor nivel y remuneración, de acuerdo con las necesidades y posibilidades de la administración pública.

Artículo 60.- Los empleados de estatuto simplificado contratados con más de un (1) año de servicio en cualesquiera de los órganos y entidades de la administración pública, en los casos de cese injustificado tendrán derecho a una indemnización equivalente al sueldo de un (1) mes por cada año de trabajo o fracción superior a seis (6) meses, sin que el monto de la indemnización pueda exceder los salarios de dieciocho (18) meses de labores. Dicha indemnización será pagada con cargo al presupuesto del órgano o entidad respectiva. El cálculo de la indemnización se realizará con base al monto nominal del último sueldo.

Artículo 61.- Las empleadas de estatuto simplificado contratadas que se encuentren en situación de embarazo, sólo podrán ser despedidas en los casos en que incurran en las faltas de tercer grado previstas en la presente ley en cuanto les sean aplicables. En todo caso, su destitución requerirá la opinión previa favorable de la Secretaría de Estado de Función Pública.

Artículo 62.- En todos los casos, las solicitudes de pagos de prestaciones económicas a los funcionarios y servidores públicos de estatuto simplificado, los titulares de los órganos o entidades de la administración pública tendrán un plazo de quince (15) días, contados a partir de que le sea comunicada la decisión que declare injustificado el despido, para tramitar el pago de las sumas a que se refiere el párrafo precedente.

Artículo 63.- En todos los casos, los pagos de prestaciones económicas a los funcionarios y servidores públicos de estatuto simplificado, serán efectuados por la administración en un plazo no mayor de 90 días a partir del inicio del trámite.

Artículo 64.- El funcionario de carrera, en los casos en que su cargo sea suprimido por interés institucional y no exista puesto de trabajo vacante, ni califique para recibir pensión o jubilación, tendrá derecho a una indemnización equivalente al sueldo de un (1) mes por 
cada año de trabajo o fracción superior a seis (6) meses, sin que el monto de la indemnización pueda exceder los salarios de dieciocho (18) meses de labores. Dicha indemnización será pagada mensualmente con cargo al presupuesto del órgano o entidad que produjo la separación del servicio por supresión del cargo, en base al monto nominal del último sueldo.

De la misma manera se procederá si son varios los aspirantes a reingreso en una misma clase de cargo. Si el número de tales cargos resulta insuficiente para reincorporar a esos aspirantes en forma simultánea, éstos serán reincorporados paulatinamente, siguiendo al efecto un orden de mayor a menor antigüedad en el servicio.

Artículo 65.- El empleado público de estatuto simplificado que tenga derecho a una pensión o jubilación de conformidad con las leyes vigentes, no podrá ser destituido injustamente, y seguirá percibiendo su salario hasta que dicha pensión o jubilación le sea concedida.

El servidor de carrera al cumplir los requerimientos de edad y años en servicios previstos para su retiro tiene derecho a recibir la pensión o jubilación que conforme a la ley le corresponda.

Artículo 66.- El titular del órgano o entidad a la que pertenezca el empleado público realizará los trámites necesarios por ante las instancias competentes a los fines de que reciba los beneficios de su pensión o jubilación en el menor tiempo posible.

Hasta tanto el servidor público de carrera reciba su pensión o jubilación, tiene derecho a retirarse del servicio y la institución tendrá la obligación de mantenerlo en nómina.

El titular de la institución que no cumpla con la obligación que le impone este artículo, de tramitar la solicitud de pensión o jubilación del servidor público, incurrirá a los fines disciplinarios en falta de segundo grado, sin perjuicio de la responsabilidad patrimonial que le podrá ser exigida ante la jurisdicción contencioso-administrativa.

\section{CAPÍTULO II \\ DE LOS DERECHOS COLECTIVOS}

Artículo 67.- Se reconoce el derecho de los servidores públicos a organizarse dentro del marco de las disposiciones de la presente ley y de cualquier otra norma legal vigente sobre la materia, conforme lo establece la Constitución de la República, así como a separarse en cualquier momento de la organización a que pertenezcan.

La reglamentación de la presente ley regulará las modalidades para la constitución y organización de las asociaciones de servidores públicos, así como de las federaciones y confederaciones de las mismas.

Artículo 68.- Las asociaciones de servidores públicos, las federaciones y las confederaciones, adquieren personalidad jurídica por efecto de su registro en la Secretaría 
de Estado de Administración Pública, la que expedirá la correspondiente certificación. Son nulos los actos ejecutados por una organización de servidores públicos que no haya sido registrada por la Secretaría de Estado de Administración Pública.

Para los fines de su formal registro por ante la Secretaria de Estado de Administración Pública, los promotores u organizadores deben remitir a ésta una solicitud acompañada de los documentos que se establezcan reglamentariamente. Dicho registro sólo puede ser negado:

1. Si los estatutos no contienen las disposiciones esenciales para el funcionamiento regular de la organización, o si alguna de sus disposiciones es contraria a la presente ley;

2. Si no se cumple cualesquiera de los requisitos exigidos por la ley o por los estatutos para la constitución de dicha organización.

Artículo 69.- Las organizaciones de empleados públicos tienen los fines siguientes:

1. Defender y proteger los derechos que la ley y los reglamentos reconocen a los servidores públicos;

2. Procurar el mejoramiento profesional, cultural, moral y social de sus miembros;

3. Colaborar con la administración pública para el mejor cumplimiento de las actividades de ésta y el mejor desempeño de los servidores públicos;

4. Representar a sus miembros ante los organismos administrativos y jurisdiccionales competentes;

5. Dar asesoramiento y asistencia a sus miembros;

6. Constituir, financiar y administrar, conforme con las normas vigentes, fondos de asistencia y promover cooperativas, centros de capacitación y perfeccionamiento profesional, entidades de recreación, bibliotecas, publicaciones y demás servicios de índole cultural destinados al desarrollo integral de sus miembros.

Artículo 70.- Se prohibe a las asociaciones, federaciones y confederaciones de servidores públicos todo tipo de actividad distinta o contradictoria con los fines establecidos en la presente ley. El registro de las asociaciones de servidores públicos será cancelado por sentencia de la Jurisdicción Contencioso Tributario y Administrativo cuando se dediquen a fines ajenos a lo establecido en la presente ley.

Artículo 71.- Hasta cinco (5) miembros del comité gestor de las asociaciones de servidores públicos y hasta nueve (9) miembros directivos de las mismas gozarán del fuero organizativo en ejercicio de sus cargos. Los servidores públicos amparados por el fuero 
organizativo sólo podrán ser destituidos por una de las causas establecidas en la presente ley.

El fuero organizativo protegerá a los servidores públicos hasta por un período de un (1) año después de haber cesado sus funciones directivas dentro de la asociación de que se trate.

Previo a la destitución de un servidor público protegido por el fuero organizativo, deberá apoderarse a la Jurisdicción Contencioso Administrativa, para que en un plazo de quince (15) días se pronuncie en función de si la causa que se invoca justifica o no la destitución, a la luz de lo que dispone la presente ley.

\section{CAPÍTULO III DE LOS RECURSOS}

Artículo 72.- Los servidores públicos tendrán derecho a interponer los recursos administrativos de reconsideración y jerárquico, con el objetivo de producir la revocación del acto administrativo que les haya producido un perjuicio, agotados los cuales podrán interponer el recurso contencioso-administrativo por ante la Jurisdicción Contenciosa Administrativa.

Artículo 73.- El Recurso de Reconsideración deberá interponerse por escrito, por ante la misma autoridad administrativa que haya adoptado la decisión considerada injusta, en un plazo de quince (15) días francos contados a partir de la fecha de recepción de la notificación de dicha decisión. Este recurso podrá ser interpuesto directamente por el servidor público afectado, o por un apoderado de éste. El plazo de quince (15) días francos otorgado para el ejercicio de este recurso de reconsideración se interrumpe si el servidor público somete su caso a un procedimiento de conciliación ante la Comisión de Personal correspondiente, hasta que ésta haya comunicado al servidor público el Acta de Acuerdo o de No Acuerdo. Transcurridos treinta (30) días sin que la autoridad responsable de conocer del recurso de reconsideración se haya pronunciado sobre el mismo, se considerará confirmada la decisión recurrida y podrá interponerse el recurso jerárquico contra la misma.

Artículo 74.- El Recurso Jerárquico deberá ejercerse ante el órgano de la administración pública de jerarquía inmediatamente superior al órgano que haya tomado la decisión controvertida, dentro de los quince (15) días francos contados a partir de la fecha de recepción de la resolución que resuelva el Recurso de Reconsideración o de la fecha en que se considere confirmada la decisión recurrida. Transcurridos treinta (30) dias sin que la autoridad responsable de conocer del recurso jerárquico se haya pronunciado sobre el mismo, se considerará confirmada la decisión recurrida y podrá interponerse el recurso contencioso-administrativo por ante la Jurisdicción Contenciosa Administrativa.

Artículo 75.- Después de agotado los recursos administrativos indicados en la presente ley, el servidor público afectado por una decisión administrativa podrá interponer el recurso contencioso administrativo por ante la Jurisdicción Contenciosa Administrativa. Este recurso deberá ser interpuesto dentro de los treinta (30) días francos, contados a partir de la fecha de recepción de la decisión que resuelva el recurso jerárquico o de la fecha en que se 
considere confirmada la decisión recurrida.

Artículo 76.- Es competencia de la Jurisdicción Contencioso Administrativa, independientemente de las funciones que le confiere la Ley No.1494, del 2 de agosto del 1947, y sus modificaciones, y la Ley No.13-07, del 5 de febrero del 2007:

1. Conocer y decidir acerca de las reclamaciones y peticiones que eleven los servidores públicos en materias disciplinarias, y de otra índole contempladas en la presente ley y sus reglamentos complementarios, y en los respectivos estatutos de personal de tales organismos, cuando no haya sido posible resolverla por vía administrativa directa;

2. Cumplir las demás funciones que se le atribuyen en la presente ley o en la reglamentación complementaria.

\section{TÍTULO IX \\ RÉGIMEN ÉTICO Y DISCIPLINARIO \\ CAPÍTULO I \\ DE SUS PRINCIPIOS RECTORES}

Artículo 77.- A los efectos del régimen ético y disciplinario, serán considerados como principios rectores de la conducta de los servidores públicos de los órganos y entidades de la administración pública, los siguientes:

1. Cortesía: Se manifiesta en el trato amable y de respeto a la dignidad en las relaciones humanas;

2. Decoro: Impone al servidor público respeto para sí y para los ciudadanos que demanden algún servicio;

3. Discreción: Requiere guardar silencio de los casos que se traten cuando éstos ameriten confidencia;

4. Disciplina: Significa la observancia y el estricto cumplimiento de las normas administrativas y de derecho público por parte de los servidores públicos en el ejercicio de sus funciones;

5. Honestidad: Refleja el recto proceder del individuo;

6. Vocación de Justicia: Obliga a los servidores públicos a actuar con equidad y sin discriminación por razones políticas, religión, etnia, posición social y económica, o de otra índole;

7. Lealtad: Manifestación permanente de fidelidad hacia el Estado, que se traduce en solidaridad con la institución, superiores, compañeros de labores y subordinados, 
dentro de los límites de las leyes y de la ética;

8. Probidad: Conducta humana considerada como reflejo de integridad, honradez y entereza;

9. Pulcritud: Entraña manejo adecuado y transparente de los bienes del Estado;

10. Vocación de Servicio: Se manifiesta a través de acciones de entrega diligente a las tareas asignadas e implica disposición para dar oportuna y esmerada atención a los requerimientos y trabajos encomendados.

Artículo 78.- El régimen ético y disciplinario de los servidores públicos, sin importar la naturaleza de su vínculo funcionarial, está dirigido a fomentar la eficiencia y eficacia de los servicios públicos y el sentido de pertenencia institucional, a fin de promover el cumplimiento del bien común, el interés general y preservar la moral pública.

Artículo 79.- Son deberes de los servidores públicos, los siguientes:

1. Cumplir y hacer cumplir la Constitución de la República, las leyes, los reglamentos, manuales, instructivos, y otras disposiciones emanadas de autoridades competentes;

2. Prestar el servicio personalmente con dedicación, eficiencia, eficacia, honestidad e imparcialidad en las funciones que se le encomienden de acuerdo con su jerarquía y cargo;

3. Cumplir la jornada de trabajo, dedicando la totalidad del tiempo al desempeño integro y honesto de sus funciones;

4. Obedecer toda orden de su superior jerárquico que tenga por objeto la realización de servicio acorde con las funciones propias y complementarias del servidor público;

5. Actuar imparcialmente en el desempeño de sus tareas dando trato y servicio por igual a quien la ley señale, sin discriminaciones político partidista, de género, religiosas, étnicas o de otro tipo, absteniéndose de intervenir en aquellos casos que puedan dar origen a interpretaciones de parcialidad, así como con otros criterios que sean incompatibles con los derechos humanos;

6. Responder del ejercicio de la autoridad que les haya sido otorgada y de la ejecución de las órdenes que impartan y por la que corresponde a sus subordinados;

7. Dar un tratamiento cortés y considerado a sus superiores, compañeros de labores y subordinados, y compartir sus tareas con espíitu de solidaridad y unidad de propósito;

8. Observar permanentemente en sus relaciones con el público toda la consideración y 
cortesía debidas a la dignidad de éste;

9. Guardar la reserva y confidencialidad que requieren los asuntos relacionados con su trabajo, y especialmente los concernientes al Estado en razón de su naturaleza o en virtud de instrucciones especiales, aún después de haber cesado en el cargo;

10. Denunciar ante cualquier superior jerárquico los hechos ilícitos y delictivos de los que tuvieran conocimiento;

11. Hacer del conocimiento de las autoridades correspondientes los hechos que puedan perjudicar al Estado, a la sociedad y al órgano o entidad en donde laboran;

12. Desarrollar las iniciativas que sean útiles para el mejoramiento del servicio;

13. Vigilar y salvaguardar los intereses, valores, bienes, equipos y materiales del Estado, principalmente los que pertenezcan a su área de trabajo o estén bajo su responsabilidad;

14. Responder por el oportuno y debido manejo de los documentos, expedientes y útiles confiados a su guarda o administración, procurar con esmero su conservación y rendir debida y oportuna cuenta de su utilización, tramitación y cuidado;

15. Atender debidamente las actividades de inducción, formación y capacitación y efectuar las prácticas y las tareas que tales actividades conlleven;

16. Cualquier otro que se encuentre previsto en el ordenamiento jurídico.

\section{CAPÍTULO II DE LAS PROHIBICIONES}

Artículo 80.- A los servidores públicos les está prohibido incurrir en los actos descritos a continuación y que la presente ley califica como faltas disciplinarias, independientemente de que constituyan infracciones penales, civiles o administrativas consagradas y sancionadas en otras leyes vigentes:

1. Solicitar, aceptar o recibir, directamente o por medio de persona interpuesta, gratificaciones, dádivas, obsequios, comisiones o recompensas, como pago por actos inherentes a sus cargos;

2. Solicitar, aceptar o recibir ventajas o beneficios en dinero o en especie, por facilitar a terceros la adquisición de bienes y servicios del Estado, o facilitar a éstos la venta de los mismos;

3. Prestar, a título particular y en forma remunerada, servicios de asesoría o de asistencia al Estado, relacionados con las funciones propias de sus cargos; 
4. Recibir más de una remuneración con cargo al erario excepto que estuviera expresamente prevista en las leyes o reglamentos;

5. Aceptar designación para desempeñar en forma simultánea más de un cargo del Estado, salvo cuando se trate de labores docentes, culturales, de investigación y las de carácter honorífico, no afectadas por incompatibilidad legal, y con la debida reposición horaria cuando hubiera superposición de este tipo. La aceptación de un segundo cargo público incompatible con el que se esté ejerciendo, supone la renuncia automática del primero sin desmedro de la responsabilidad que corresponda;

6. Obtener préstamos y contraer obligaciones con personas naturales o jurídicas con las cuales se tengan relaciones oficiales en razón de los cargos públicos que desempeñan;

7. Intervenir, directa o indirectamente, en la suscripción de contratos con el Estado a través de la institución donde labora y en la obtención de concesiones o beneficios que impliquen privilegio oficial en su favor, salvo en los casos en que por mandato de la ley los deban suscribir;

8. Asistir al lugar de trabajo en estado de embriaguez o bajo el influjo de drogas o sustancias estupefacientes;

9. Participar en actividades oficiales en las que se traten temas sobre los cuales el servidor público tenga intereses particulares económicos, patrimoniales o de índole política que en algún modo planteen conflictos de intereses;

10. Valerse de sus influencias jerárquicas para acosar sexualmente a servidores públicos en el Estado, o valerse del cargo para hacerlo sobre ciudadanos que sean usuarios o beneficiarios de servicios del órgano o entidad a la que pertenezca el servidor público;

11. Requisar, sustraer o copiar informaciones de manejo exclusivo propio o de otros compañeros de trabajo, sin la expresa autorización de éstos o de su superior inmediato, todo esto sin desmedro de lo establecido en legislaciones vigentes;

12. Representar o patrocinar a litigantes o intervenir en gestiones extrajudiciales contra la administración pública, excepto en casos de defensa de intereses personales del servidor público, de su cónyuge y de sus parientes consanguíneos o afines en primer grado;

13. Servir intereses de partidos en el ejercicio de sus funciones, y en consecuencia, organizar o dirigir demostraciones, pronunciar discursos partidistas, distribuir propaganda de carácter político, o solicitar fondos para los mismos fines, así como utilizar con este objetivo los bienes y fondos de la institución; 
$-29-$

14. Requerir, inducir u obligar a sus subaltemos a participar en actividades políticas o partidistas, sea en su provecho o en provecho de terceros;

15. Prestar servicios en la misma institución que su cónyuge y quienes estén unidos por lazos de consanguinidad o afinidad hasta el segundo grado inclusive, cuando tuvieran relación de jerarquía;

16. Actuar en aquellos casos en que tengan intereses particulares que planteen conflictos de intereses para el servidor público;

17. Incurrir en las demás prohibiciones que se establezcan por vía legal o reglamentaria.

\section{CAPÍTULO III \\ DEL RÉGIMEN DISCIPLINARIO: \\ FALTAS Y SANCIONES}

Artículo 81.- El régimen disciplinario de los servidores públicos estará fundamentado en la gradación de las faltas, en la forma que se indica a continuación:

1. Faltas de primer grado, cuya comisión será sancionada con amonestación escrita;

2. Faltas de segundo grado, cuya comisión dará lugar a la suspensión hasta por noventa (90) días sin disfrute de sueldo;

3. Faltas de tercer grado, cuya comisión dará lugar a la destitución del servicio.

No serán reputadas sanciones disciplinarias los consejos, observaciones y advertencias verbales formuladas al servidor público en interés del servicio.

De todas las sanciones disciplinarias se dejará constancia en el historial de servicio del servidor público.

Artículo 82.- Son faltas de primer grado, cuya comisión da lugar a una amonestación escrita, las siguientes:

1. Descuidar el rendimiento y la calidad del trabajo;

2. Llegar tarde al trabajo de manera reiterada;

3. Proponer o establecer de manera consciente trámites innecesarios en el trabajo;

4. Suspender las labores sin la autorización previa de la autoridad del superior jerárquico;

5. Negarse a colaborar en alguna tarea relacionada con las de su cargo o con las de 
$-30-$

otros compañeros de labores, cuando se lo haya solicitado una autoridad competente de la jornada de trabajo.

6. Dejar de asistir al trabajo durante un (1) día sin aprobación previa de la autoridad competente o causa justificada;

7. Procurar o permitir que otro empleado marque o firme en su lugar el medio de control de asistencia al trabajo establecido, o hacerlo en lugar de otro;

8. Incurrir en cualquier otro hecho u omisión calificable como falta de primer grado a juicio de la autoridad sancionadora y que no amerite una sanción mayor.

Artículo 83.- Son faltas de segundo grado cuya comisión da lugar a la suspensión de funciones por hasta noventa (90) días, sin disfrute de sueldo, las siguientes:

1. Reincidir en la comisión de faltas de primer grado;

2. Dejar de evaluar y calificar el desempeño anual de sus subalternos dentro de los plazos oficialmente establecidos;

3. Tratar reiteradamente en forma irrespetuosa, agresiva, desconsiderada u ofensiva a los compañeros, subalternos, superiores jerárquicos y al público;

4. Realizar en el lugar de trabajo actividades ajenas a sus deberes oficiales;

5. Descuidar reiteradamente el manejo de documentos y expedientes, ocasionando daños y perjuicios a los ciudadanos y al Estado;

6. Establecer contribuciones forzosas en beneficio propio o de terceros, valiéndose de su autoridad o cargo;

7. Difundir, hacer circular, retirar o reproducir de los archivos de las oficinas documentos o asuntos confídenciales o de cualquier naturaleza que los servidores públicos tengan conocimiento por su investidura oficial, todo esto sin menoscabo de lo establecido en la legislación;

8. Utilizar vehículos, equipos o bienes propiedad del Estado, sin la autorización de funcionario competente;

9. Realizar actividades partidistas, así como solicitar o recibir dinero u otros bienes con fines políticos en los lugares de trabajo;

10. Promover o participar en huelgas ilegales;

11. Incurrir en cualesquier otros hechos u omisiones reputados como similares a los 
previstos en este artículo.

Artículo 84.- Constituyen faltas de tercer grado cuya comisión dará lugar a la destitución del cargo, las acciones indicadas a contimuación cometidas por cualquier servidor de la administración pública:

1. Manejar fraudulentamente fondos o bienes del Estado para provecho propio o de otras personas;

2. Realizar, encubrir, excusar o permitir, en cualquier forma, actos que atenten gravemente contra los intereses del Estado o causen, intencionalmente o por negligencia manifiesta, grave perjuicio material al patrimonio del Estado;

3. Dejar de asistir al trabajo durante tres (3) días laborables consecutivos, o tres (3) días en un mismo mes, sin permiso de autoridad competente, o sin una causa que lo justifique, incurriendo así en el abandono del cargo;

4. Incurrir en la falta de probidad, vías de hecho, injuria, difamación o conducta inmoral en el trabajo, o realizar algún acto lesivo al buen nombre del Estado o algunos de sus órganos o entidades;

5. Beneficiarse económicamente o beneficiar a terceros, debido a cualquier clase de contrato u operación del órgano o entidad en que intervenga el servidor público en el ejercicio de su cargo;

6. Asociarse, bajo cualquier título y razón social, a personas o entidades que contraten con el órgano o entidad al cual el servidor público presta sus servicios. Asimismo, tener participación por sí o por interpuestas personas, en firmas o sociedades que tengan relaciones económicas con el órgano o entidad donde trabaja el servidor público, cuando estas relaciones estén vinculadas directamente con el cargo que desempeña, salvo que el empleado haya hecho conocer por escrito esta circunstancia para que se le releve de su conocimiento, la tramitación o la autorización del asunto de que se trate;

7. Solicitar, aceptar o recibir, directamente o por intermedio de otros, cualquier título, comisiones, dádivas, gratificaciones en dinero o en especie $u$ otros beneficios indebidos, por intervenir en la venta o suministro de bienes, o por la prestación de servicios del Estado. A este efecto, se presume como beneficios indebidos todos los que reciba el servidor público, su cónyuge, sus parientes hasta el tercer grado de consanguinidad o segundo grado de afinidad, inclusive, siempre que se pruebe en forma cierta e inequivoca una relación de causa efecto entre las actuaciones del servidor público y los beneficios de que se ha hecho mención;

8. Prestar a título oneroso servicios de asesoría o de asistencia a órganos o entidades del Estado; 
9. Obtener préstamos o contraer obligaciones con personas naturales o jurídicas con las cuales el servidor público tenga relaciones en razón del cargo que desempeña;

10. Cobrar viáticos, sueldos, dietas, gastos de representación, bonificaciones u otros tipos de compensaciones por servicios no realizados, o por un lapso mayor al realmente utilizado en la realización del servicio;

11. Expedir certificaciones y constancias que no correspondan a la verdad de los hechos certificados;

12. Ser condenado penalmente con privación de libertad, por la comisión de un crimen o delito, mediante sentencia definitiva;

13. Aceptar de un gobierno extranjero o de un organismo internacional, un cargo, función, merced, honor o distinción de cualquier índole, sin previo permiso del Poder Ejecutivo;

14. Valerse de influencias jerárquicas para acosar sexualmente a servidores públicos en el Estado, o valerse del cargo para hacerlo sobre ciudadanos que sean usuarios o beneficiarios de servicios del órgano o entidad a la que pertenezca el servidor público;

15. Demorar o no tramitar en los plazos establecidos, el pago de las indemnizaciones económicas previstas para los servidores públicos por la presente ley y su reglamentación complementaria;

16. Incumplir las instrucciones del órgano central de personal y las decisiones de la Jurisdicción Contencioso Administrativa;

17. Llevar una conducta pública o privada que impida la normal y aceptable prestación de los servicios a su cargo;

18. Auspiciar o celebrar reuniones que conlleven interrupción de las labores de la institución;

19. Negarse a prestar servicio en caso de calamidad pública, a las autoridades correspondientes, cuando las mismas estén actuando en función de defensa civil o de soconro a la comunidad;

20. Cometer cualesquiera otras faltas similares a las anteriores por su naturaleza o gravedad, a juicio de la autoridad sancionadora;

21. Reincidir en cualesquiera de las faltas calificadas como de segundo grado.

El servidor público destituido por haber cometido cualesquiera de las faltas señaladas en este artículo, quedará inhabilitado para prestar servicios al Estado por un periodo de cinco 
(5) años, contados a partir de la fecha de notificación de la destitución.

\section{CAPÍTULO IV \\ DEL PROCEDIMIENTO DISCIPLINARIO}

Artículo 85.- Corresponde al supervisor inmediato del servidor público la facultad para imponer la amonestación escrita, cuando se hubiere cometido una falta de primer grado.

Corresponde al titular del órgano o entidad a la cual pertenece el servidor público la facultad para imponer la suspensión hasta por noventa (90) días, cuando se hubiere cometido una falta de segundo grado.

Artículo 86.- El ejercicio de la potestad disciplinaria en la administración pública centralizada es competencia del Presidente de la República cuando la falta cometida implique la destitución. En tal caso, el titular de la entidad a la que pertenezca el servidor público será responsable de elevar al Presidente la recomendación de lugar, luego de agotado el proceso disciplinario a que se refiere esta ley.

En las instituciones descentralizadas y/o autónomas o autárquicas y especiales, la potestad disciplinaria en los casos de faltas que tengan como sanción la destitución, salvo disposición legal en contrario, es privativa de la autoridad nominadora.

Artículo 87.- Cuando el servidor público estuviere presuntamente incurso en una causal de destitución, se procederá de la siguiente manera:

1. El funcionario de mayor jerarquía dentro de la respectiva unidad, solicitará a la Oficina de Recursos Humanos la apertura de la averiguación a que hubiere lugar,

2. La Oficina de Recursos Humanos instruirá el respectivo expediente y determinará los cargos a ser formulados al servidor público investigado, si fuere el caso;

3. Una vez cumplido lo establecido en el numeral precedente, la Oficina de Recursos Humanos notificará al servidor público investigado para que tenga acceso al expediente y ejerza su derecho a la defensa, dejando constancia de ello en el expediente;

4. En el quinto día hábil después de haber quedado notificado el servidor público, la Oficina de Recursos Humanos le formulará los cargos a que hubiere lugar. En el lapso de cinco días hábiles siguientes, el servidor público consignará su escrito de descargo;

5. El servidor público investigado, durante el lapso previo a la formulación de cargos y dentro del lapso para consignar su escrito de descargo, tendrá acceso al expediente y podrá solicitar que le sean expedidas las copias que fuesen necesarias a los fines de la preparación de su defensa, salvo aquellos documentos que puedan ser considerados como reservados; 
6. Concluido el acto de descargo, se abrirá un lapso de cinco días hábiles para que el investigado promueva y evacue las pruebas que considere conveniente;

7. Dentro de los dos días hábiles siguientes al vencimiento del lapso de pruebas concedidas al servidor público, se remitirá el expediente a la consultoría jurídica o la unidad similar del órgano o entidad a fin de que opine sobre la procedencia o no de la destitución. A tal fin, la consultoría jurídica dispondrá de un lapso de diez días hábiles;

8. La máxima autoridad del órgano o entidad decidirá dentro de los cinco días hábiles siguientes al dictamen de la consultoría jurídica y notificará al servidor público investigado del resultado, indicándole en la misma notificación del acto administrativo el recurso jurisdiccional que procediere contra dicho acto, el tribunal por ante el cual podrá interponerlo y el término para su presentación;

9. De todo lo actuado se dejará constancia escrita en el expediente.

El incumplimiento del procedimiento disciplinario a que se refiere este artículo por parte de los titulares de las Oficinas de Recursos Humanos, será causal de destitución y nulidad del procedimiento aplicado.

Artículo 88.- Cuando para realizar una investigación judicial o administrativa fuere conveniente, a los fines de la misma, suspender a un servidor público, la suspensión será con goce de sueldo y tendrá una duración hasta de sesenta días continuos, lapso que podrá ser prorrogado por una sola vez.

La suspensión con goce de sueldo terminará por revocatoria de la medida, por decisión de sobreseimiento, por absolución en la investigación o por imposición de una sanción.

Artículo 89.- $\mathrm{Si}$ a un servidor público le ha sido dictada medida preventiva de privación de libertad, se le suspenderá del ejercicio del cargo sin goce de sueldo. Esta suspensión no podrá tener una duración mayor a seis meses.

En caso de sentencia absolutoria con posterioridad al lapso previsto en este artículo, la administración reincorporará al servidor público con el pago de los sueldos dejados de percibir durante el lapso en que estuvo suspendido.

\section{CAPÍTULO V \\ DE LA RESPONSABILIDAD CIVIL DEL ESTADO Y DEL SERVIDOR PÚBLICO}

Artículo 90.- El Estado y el servidor público o miembros del órgano colegiado actuante serán solidariamente responsables y responderán patrimonialmente por los daños y perjuicios causados por la acción u omisión del funcionario actuante. La Jurisdicción 
$-35-$

Contenciosa Administrativa será competente para conocer de dichos incumplimientos y para establecer las indemnizaciones correspondientes.

Artículo 91.- En los casos en que la persona perjudicada no haya dirigido su acción reclamatoria de daños y perjuicios contra el funcionario responsable, el Estado, condenado a resarcir el perjuicio causado por la gestión dolosa, culposa o negligente de dicho funcionario, podrá ejercer contra éste una acción en repetición.

El Procurador General Administrativo podrá, de oficio, ejercer en representación del Estado, la acción en repetición contra el funcionario responsable.

\section{CAPÍtULO VI \\ DE LA DESVINCULACIÓN DEL SERVIDOR PÚBLICO}

Artículo 92.- La terminación de las relaciones estatutarias entre el Estado y los servidores públicos se producirá de acuerdo con las situaciones jurídico-administrativas prescritas en los artículos subsiguientes.

Artículo 93.- La revocación del nombramiento es la acción tomada por la misma autoridad a la cual le correspondió expedir el nombramiento definitivo, luego de comprobar que el servidor público ha obtenido dicho nombramiento mediante la comisión de actuaciones fraudulentas o de haber procedido ese nombramiento en violación de lo establecido en el ordenamiento jurídico.

Artículo 94.- La destitución es la decisión de carácter administrativo emanada de la autoridad competente para separar a los servidores públicos.

Párrafo I.- Cuando se trate de funcionarios de libre nombramiento y remoción, interviene a su libre discreción.

Párrafo II.- Cuando se trate de funcionarios públicos de carrera, sólo podrán ser destituidos por una de las causales previstas en la presente ley. Asimismo procederá como aplicación de las sanciones previstas por el régimen disciplinario correspondiente a esta ley. Toda destitución de un servidor público de carrera deberá ser motivada tanto por la autoridad que la produzca como por la que la solicite.

Artículo 95.- La renuncia es el acto mediante el cual un servidor público ejerce su derecho de poner término a su relación de empleo con el órgano o entidad administrativa a la cual pertenece. El término de las relaciones funcionariales tendrá efecto una vez el acto de renuncia haya sido debidamente aceptado por la autoridad competente o el día siguiente de cumplido el plazo de sesenta días para su aceptación. El renunciante debe entregar a la autoridad competente, bajo inventario, los equipos, archivos, documentos y demás bienes bajo su custodia.

Artículo 96.- La pensión o jubilación por antigüedad en el servicio, por invalidez absoluta o por lesiones permanentes que le incapaciten, estarán reguladas por leyes y reglamentos 
$-36-$

destinados especificamente a tales materias.

Artículo 97.- El vencimiento del plazo previsto por el Artículo 63 ante la supresión del cargo de carrera por interés institucional produce la desvinculación del servidor público de la institución, siempre y cuando no existiere la posibilidad de ser reubicado en otro cargo.

\section{TíTULO X \\ DISPOSICIONES TRANSITORIAS, FINALES Y DEROGATORIAS \\ CAPÍTULO I \\ DISPOSICIONES TRANSITORIAS}

Artículo 98.- Los servidores públicos que a la entrada en vigencia de la presente ley ocupan cargos de carrera sin que se les haya conferido el status como servidores de carrera, serán evaluados a los fines de conferirle dicho status, en el orden que disponga la Secretaría de Estado de Administración Pública. Los servidores-públicos evaluados, de manera insatisfactoria en dos períodos consecutivos, mediando un período mínimo de seis (6) meses entre la primera y la segunda evaluación, serán destituidos en las condiciones previstas en el Artículo 49 de la presente ley.

La Secretaría de Estado de Administración Pública dispondrá de un plazo de ocho (8) años, contado a partir de la entrada en vigencia de la presente ley, para culminar con todo el proceso de evaluación de dichos servidores públicos. A partir del vencimiento de dicho plazo, quedarán sin efecto todos los nombramientos de los servidores públicos que sin haber adquirido el status de carrera, estén ocupando cargos de carrera.

A partir de la entrada en vigencia de la presente ley, ningún cargo de carrera podrá ser cubierto sin agotar los procedimientos establecidos en la misma.

Se establece como una responsabilidad de la Secretaría de Estado de Administración Pública, la Contraloría General de la República y la Dirección General de Presupuesto, de establecer las medidas que garanticen el cumplimiento de lo establecido en el presente artículo.

Artículo 99.- Hasta tanto entre en vigencia el Sistema Nacional de Seguridad Social, la titularidad de una pensión por invalidez absoluta o por lesiones permanentes generará el mantenimiento vitalicio del seguro médico al cual tenía derecho el servidor durante su actividad.

Asimismo, se garantizará el mantenimiento del seguro médico al titular de una pensión por antigüedad que así lo desee. El hecho de renunciar al beneficio de las prestaciones sociales no exime al titular de la pensión en contribuir al régimen. 
$-37-$

\section{CAPÍTULO II \\ DISPOSICIONES FINALES}

Artículo 100.- El Presidente de la República en su condición de jefe de la administración pública, a propuesta de la Secretaría de Estado de Administración Pública, dictará las políticas y disposiciones reglamentarias que aseguren la debida aplicación y respeto a la presente ley y sus principios. Las demás autoridades ejercerán estas facultades en sus respectivos ámbitos de actuación.

Artículo 101.- En los convenios o contratos que los órganos y entidades sujetos a la presente ley celebren con entidades consultoras o profesionales ajenas a la administración pública para la aplicación de la presente ley, se establecerán cláusulas que obliguen a que esos contratados deban informarse y sujetar sus prestaciones a los lineamientos necesarios para mantener la unidad y coherencia de la organización estructural, procedimental y en materia de función pública que imparta la Secretaría de Estado de Administración Pública.

Artículo 102.- A los fines de la aplicación de la presente ley, se reconoce el status de carrera a todos los servidores públicos que al momento de la entrada en vigencia de la presente ley ostenten el status de servidores de carrera, amparados por un nombramiento del Poder Ejecutivo, o que habiendo obtenido el Certificado de Aprobación del Proceso de Incorporación al Sistema de Carrera Administrativa por parte de la Oficina Nacional de Administración y Personal (ONAP), la expedición de su nombramiento se encontrare en trámite.

Artículo 103.- Las instituciones de la administración del Estado deberán establecer en sus presupuestos las apropiaciones o previsiones presupuestarias necesarias para satisfacer:

1. Las remuneraciones adicionales, los complementos económicos del cargo, los incentivos y los beneficios marginales;

2. Las previsiones para conceder indemnizaciones en los casos previstos por la presente ley; y para el pago de vacaciones en caso de desvinculación del servicio;

3. Un fondo especializado para financiar la capacitación y entrenamiento en servicio de los servidores públicos, de acuerdo con la programación elaborada por el INAP.

\section{CAPÍTULO III \\ DEROGACIONES}

Artículo 104.- La presente ley deroga y sustituye la Ley No.14-91, del 20 de mayo de 1991, de Servicio Civil y Carrera Administrativa, y su Reglamento de Aplicación No.8194, del 29 de marzo de 1994, así como la Ley No.120-01, del 20 de julio del 2001, que establece el Código de Ética del Servidor Público, y cualquier otra disposición legal o reglamentaria en cuanto le sea contraria.

Artículo 105.- La presente ley deroga, además, los Literales p) y q) del Artículo 4 y el 
$-38-$

Párrafo I del Artículo 9, en lo que respecta a la Ofícina Nacional de Administración y Personal, de la Ley No.496- 06, del 28 de diciembre del 2006, que crea la Secretaría de Estado de Economía, Planificación y Desarrollo.

DADA en la Sala de Sesiones de la Cámara de Diputados, Palacio del Congreso Nacional, en Santo Domingo de Guzmán, Distrito Nacional, capital de la República Dominicana, a los once (11) días del mes de diciembre del año dos mil siete (2007); años $164^{\circ}$ de la Independencia y $145^{\circ}$ de la Restauración.

\section{Elba Lugo A. de Alcántara \\ Presidenta Ad-Hoc}

María Cleofila Sánchez Lora

Secretaria

Teodoro Ursino Reyes Secretario

DADA en la Sala de Sesiones del Senado, Palacio del Congreso Nacional, en Santo Domingo de Guzmán, Distrito Nacional, Capital de la República Dominicana, a los cuatro (04) días del mes de enero del año dos mil ocho (2008); años 164 de la Independencia y 145 de la Restauración.

\section{Reinaldo Pared Pérez \\ Presidente}

Rubén Darío Cruz Ubiera

Secretario

Dionis Alfonso Sánchez Carrasco, Secretario

\section{LEONEL FERNÁNDEZ}

Presidente de la República Dominicana

En ejercicio de las atribuciones que me confiere el Artículo 55 de la Constitución de la República.

PROMULGO la presente Ley y mando que sea publicada en la Gaceta Oficial, para su conocimiento y cumplimiento.

DADA en Santo Domingo de Guzmán, Distrito Nacional, capital de la República Dominicana, a los dieciséis (16) días del mes de enero del año dos mil ocho (2008); años 164 de la Independencia y 145 de la Restauración. 


\subsection{Decreto no 524 de 21/07/2009 (República Dominicana)}

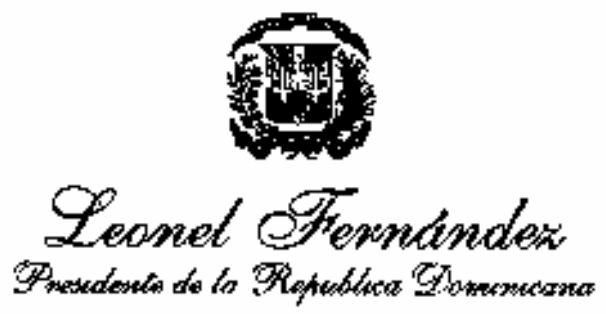

NC.MLRO 524-09

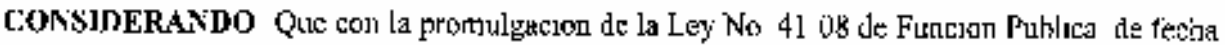

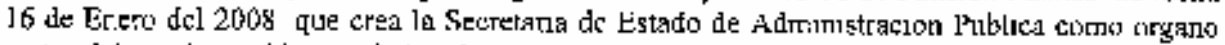

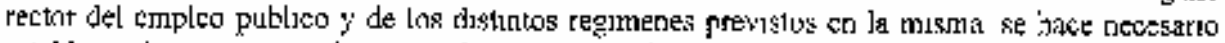

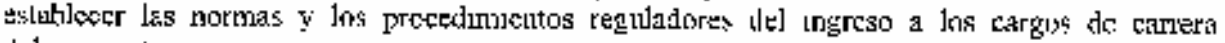

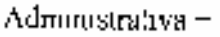

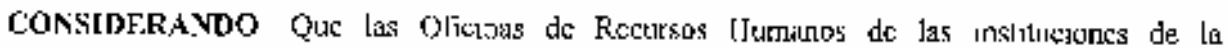

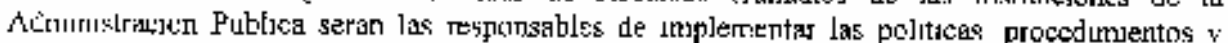

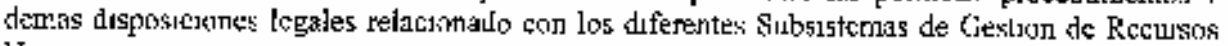
lituanosi

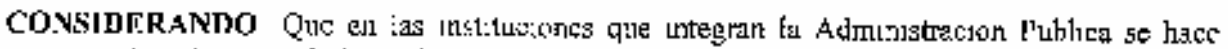

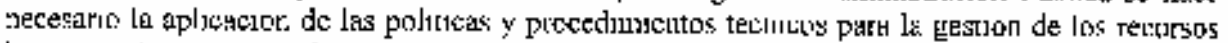

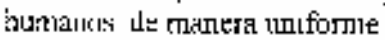

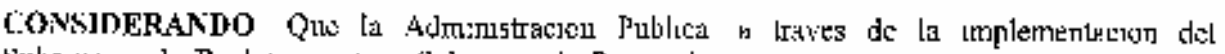

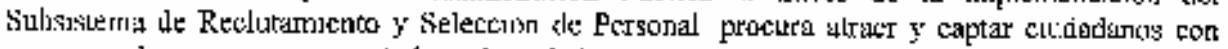

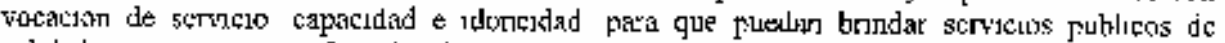

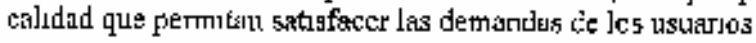

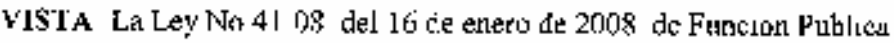

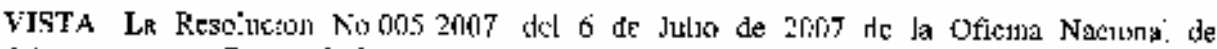

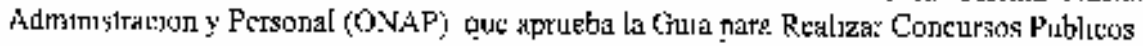

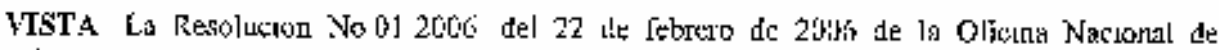

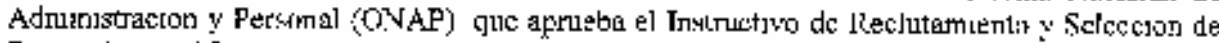

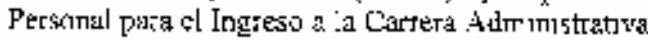

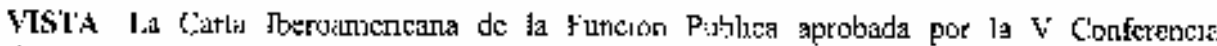

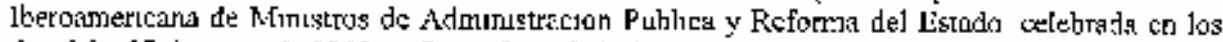

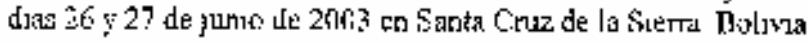




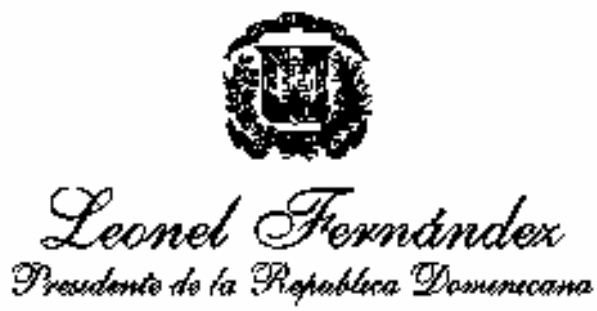

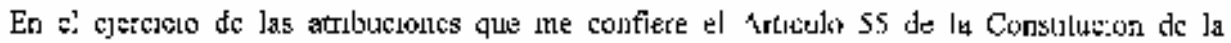

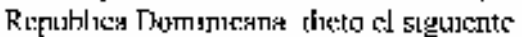

\section{REGLAHEYTO DF RFEIUTAMIENTO Y SELECCION DE PJIRSOVAT. EV LA A.DWIINISTRACION PLBLICA}

\section{CAPITE!IST \\ DJSPOSTCIONES GFNFRATES \\ OBJEITYO DLL RYCLAMEVTO}

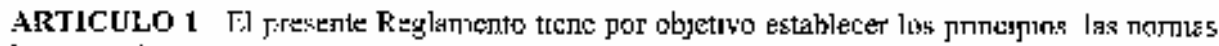

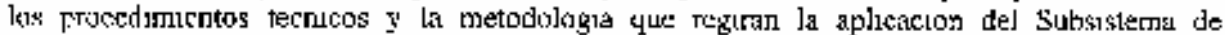

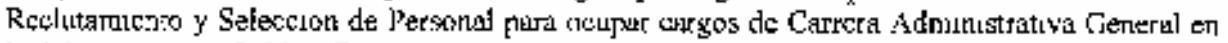

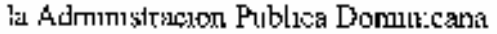

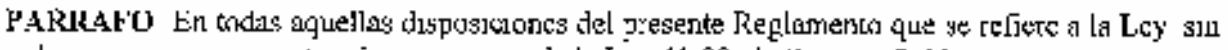

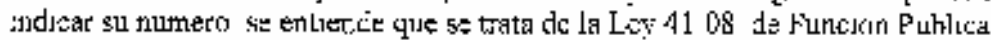

\section{AYIITO DE APLICACION}

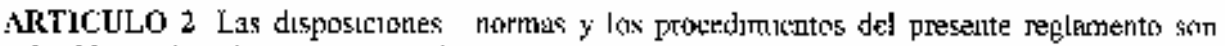

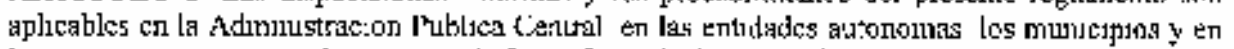

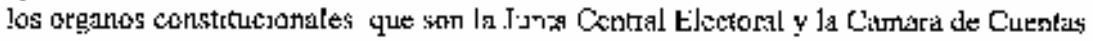

\section{EXCLLTSIONES}

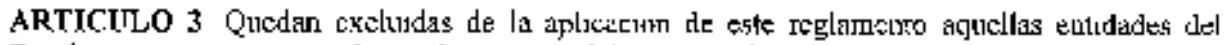

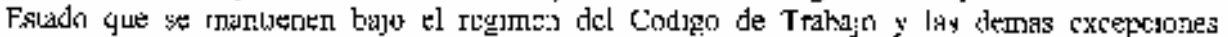

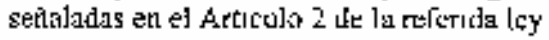

\section{PRIYCTPIOS RFCTORES DEL SLBSIS"TEHIA HE IRECLLTA HTTRTO Y SFI FCCION}

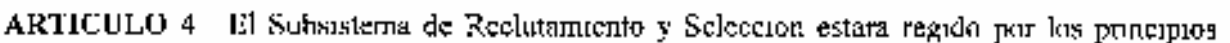
qugluelites 


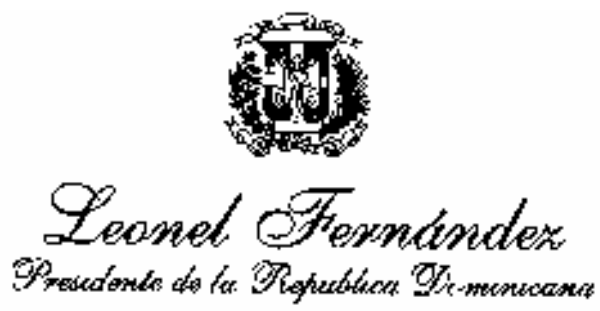

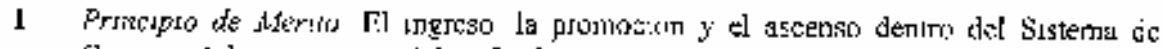

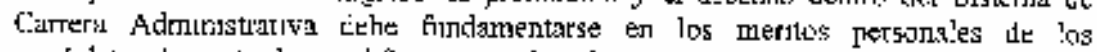
candrdatos dembs lrados en diferenter m.cd]os de comptelsucjon

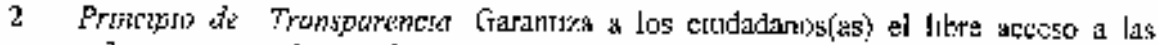

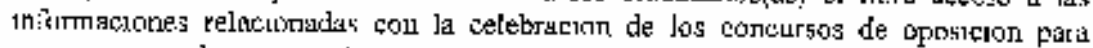

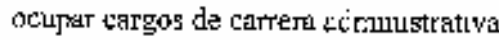

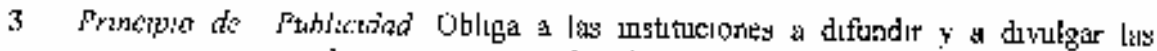

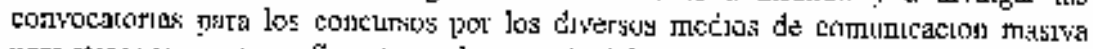

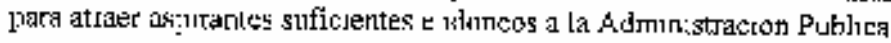

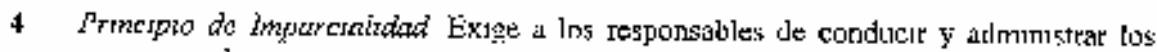

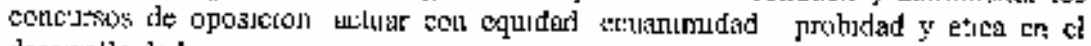
degarol lo de ios Tustros

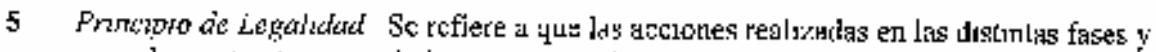

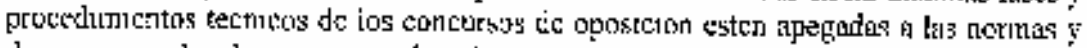

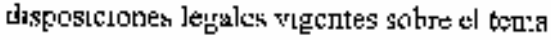

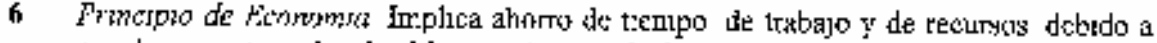

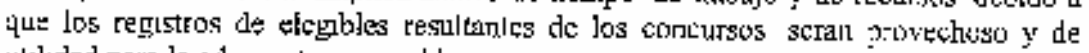

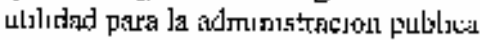

\section{GLOSARIO DL TERMTMOS}

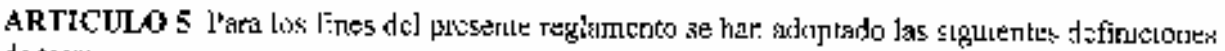
J: têJjistur:i

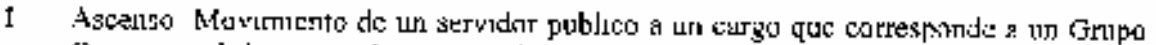

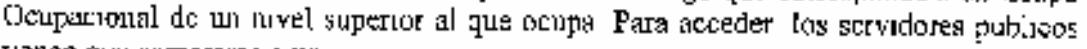

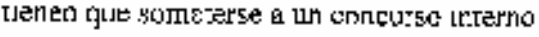

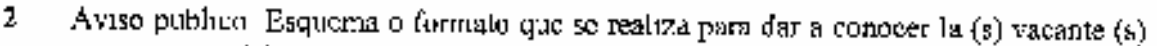

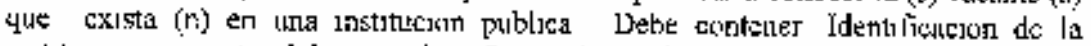

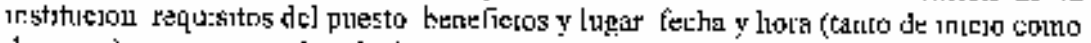

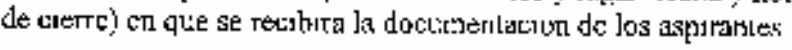




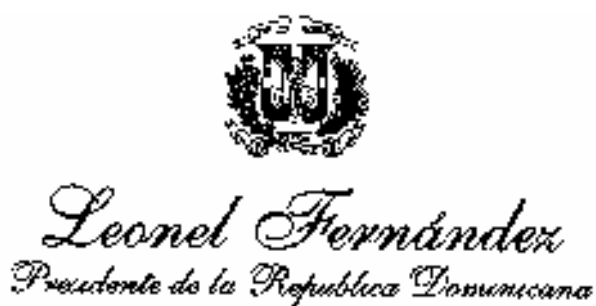

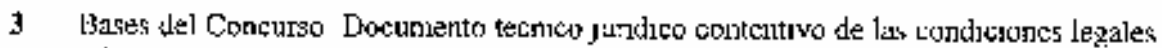

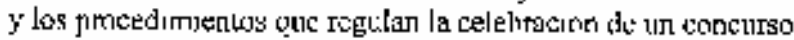

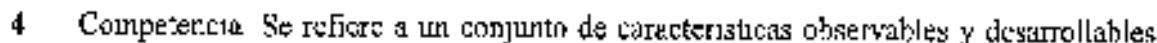

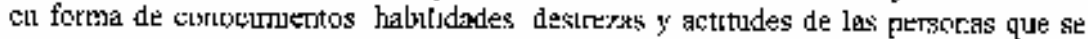

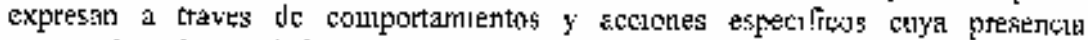

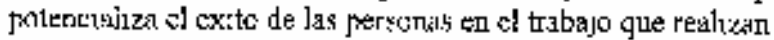

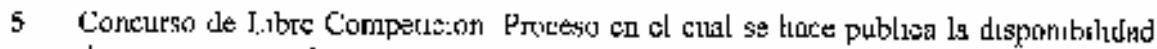

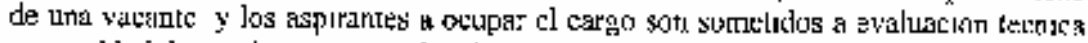

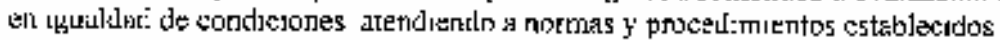

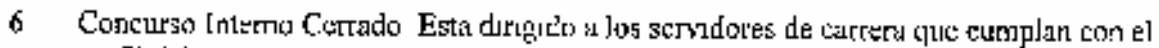

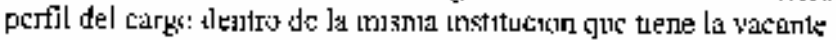

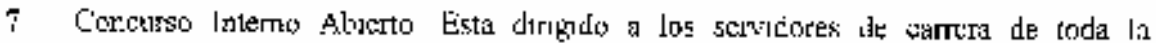

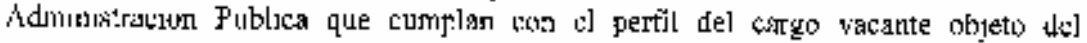
corguts:

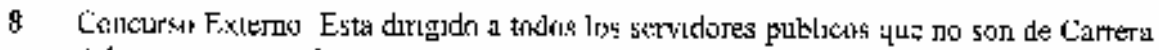

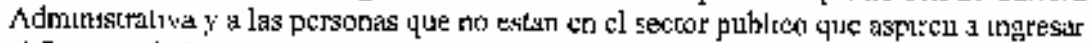
al BLstemia de Curretu

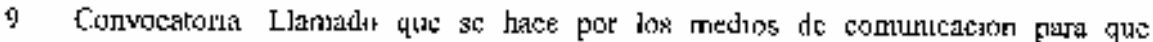

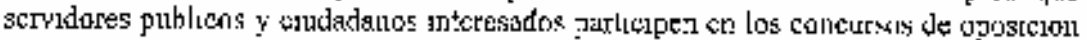
de cargos viphntes

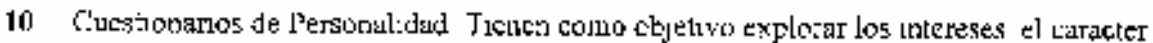

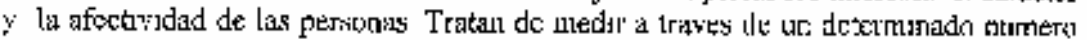

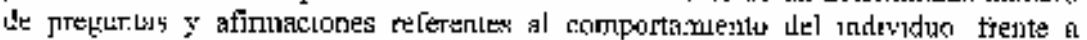

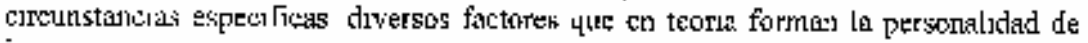
Sos Exil|tos

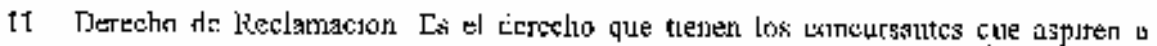

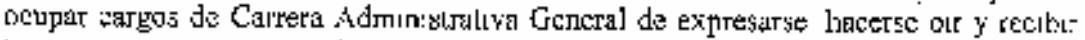

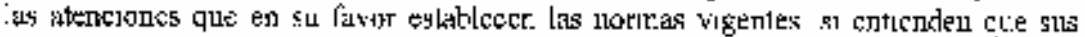

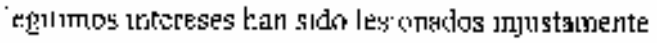




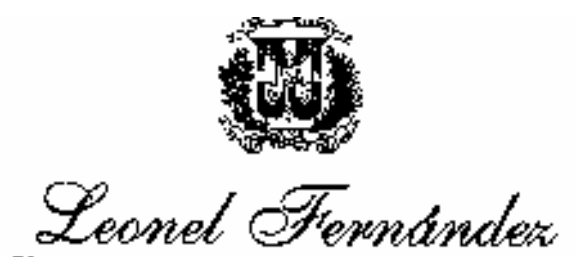

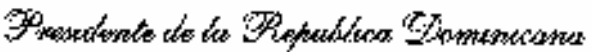

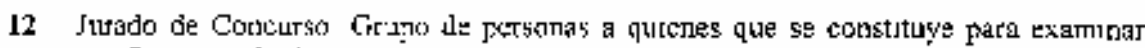

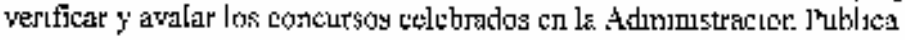

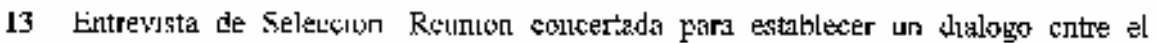

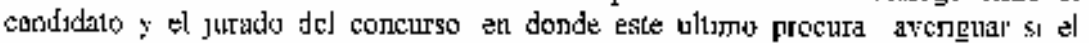

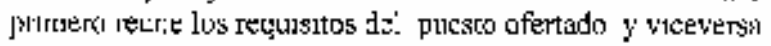

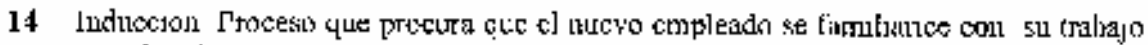

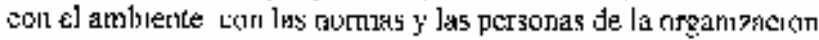

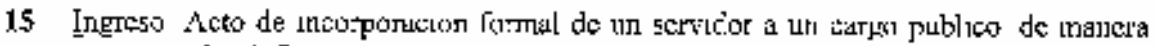
privisulal o defimatio

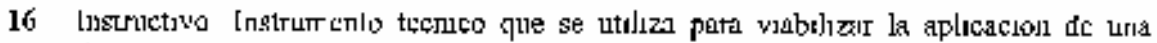

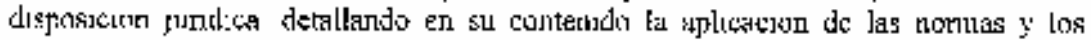
jrocedtritum|rs:

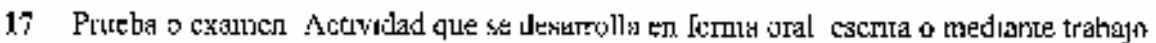

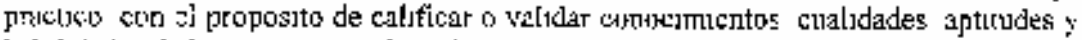

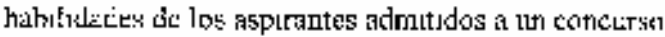

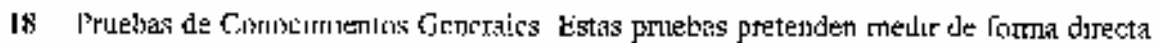

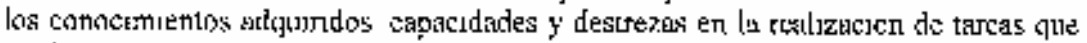

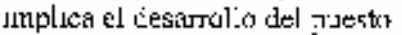

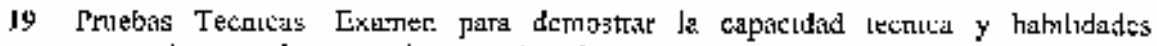
rquerid as para de termumado eqrao de trabuin

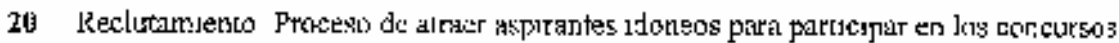

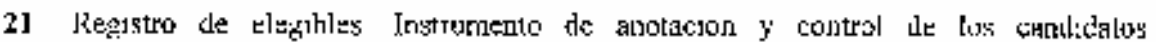

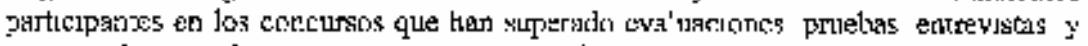
7o :

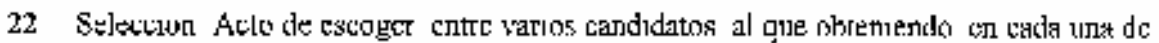

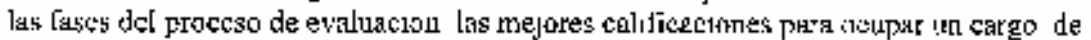

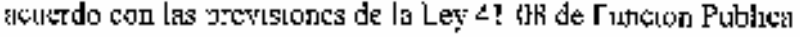




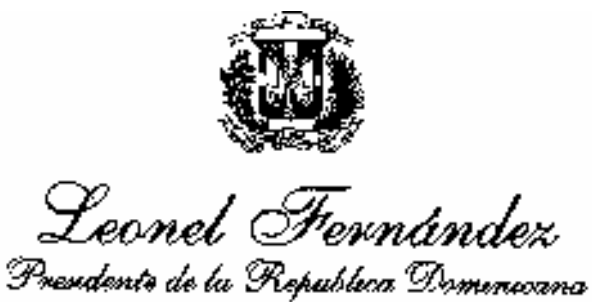

\section{DIRECCION Y ADHINISTRACLOY DEL SE BSISTRHLA DE RECLUTAHITEYTO Y SELECCIOS}

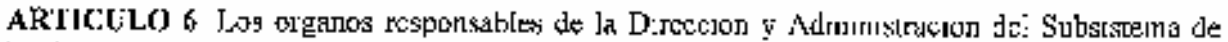

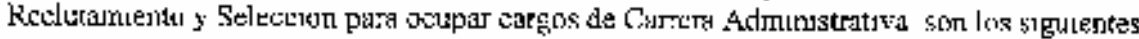

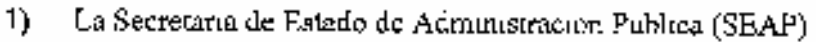

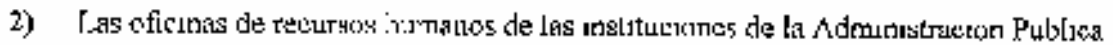

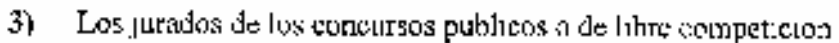

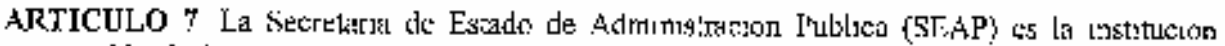

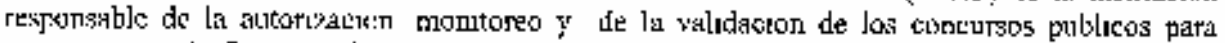

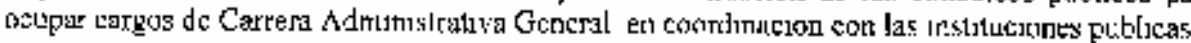

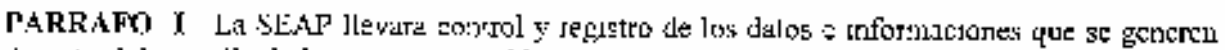

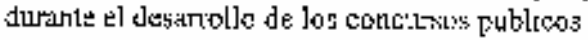

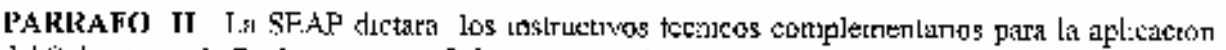

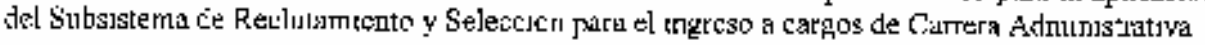

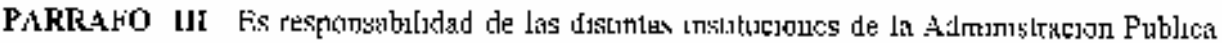

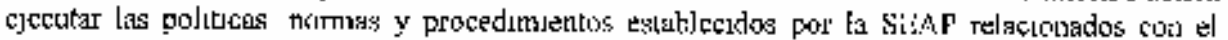

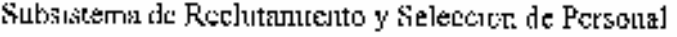

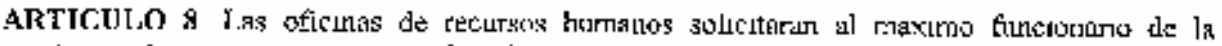

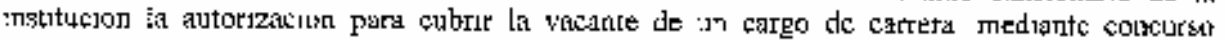
pirbieo.

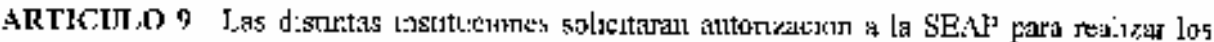

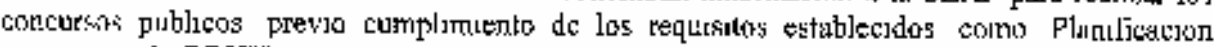

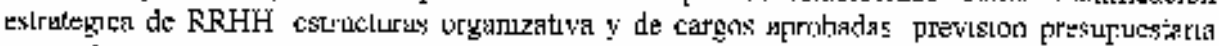

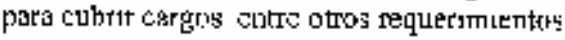

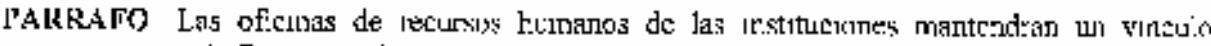

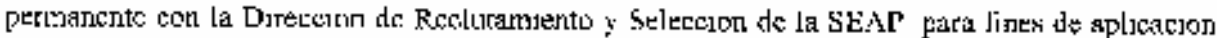

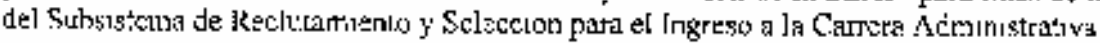




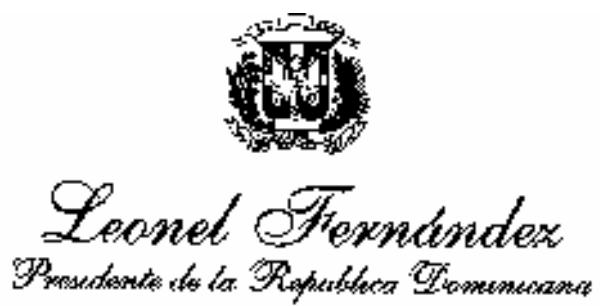

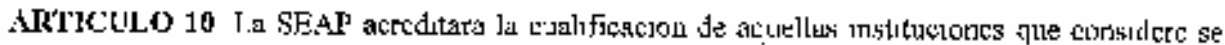

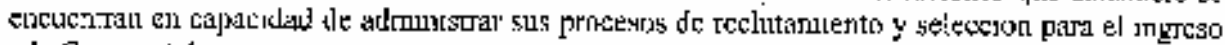
н la Cancea Admenstrati wa

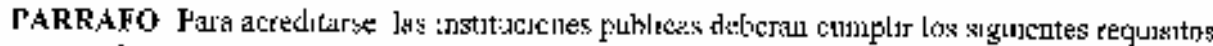

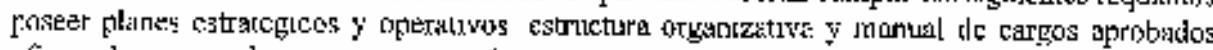

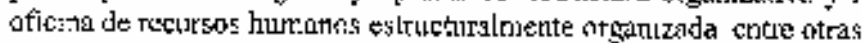

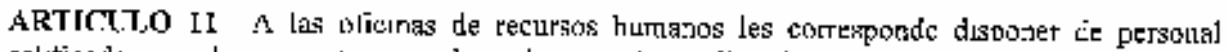

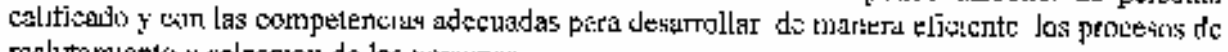

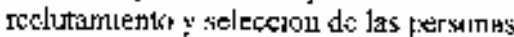

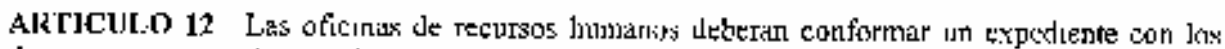

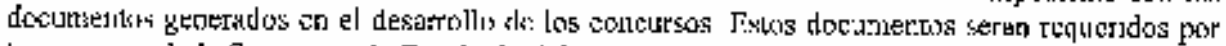

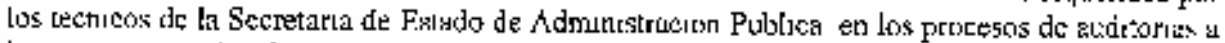
bo concut bos roaluzados

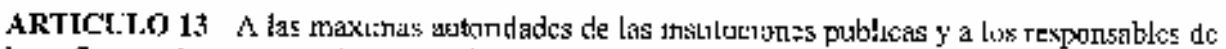

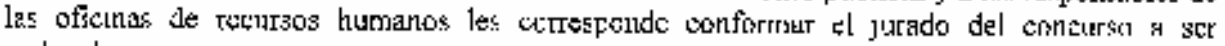
realizeds:

\section{CAFITLIITII}

\section{WLL INGRTSO AL SISI'GAA DE RARTERA AUMINISTRA TTHA GEYERAI}

\section{DE LOS RFQUISITOS GENERAIAS}

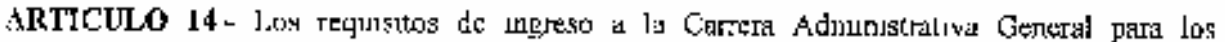

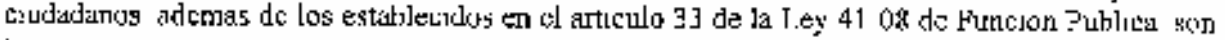

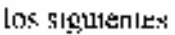

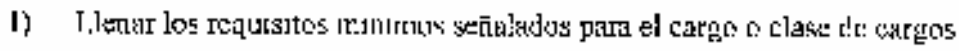

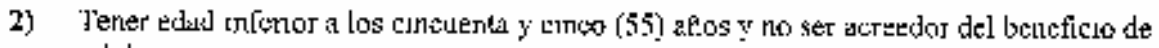
ומוis 


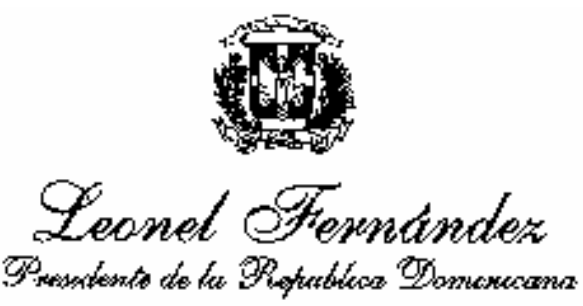

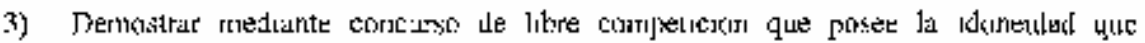
demedoda cargo o clase de carogos

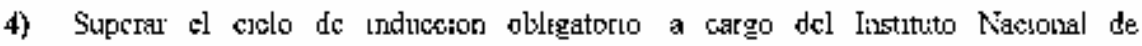

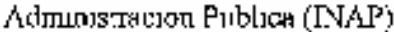

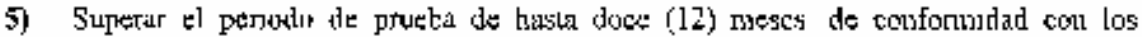
matiualey de caturis

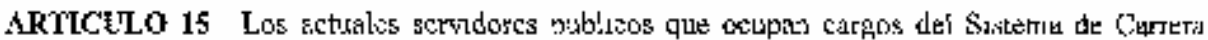

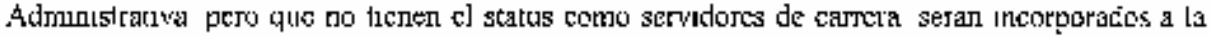

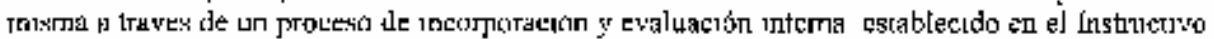

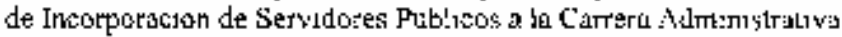

\section{DE LOS CONCITRSOS TNTERYOS PARA ASCTHEOS}

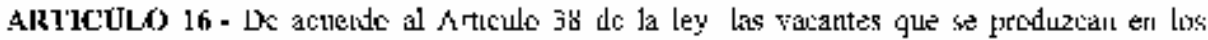

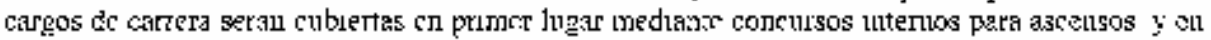

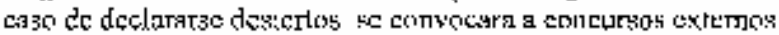

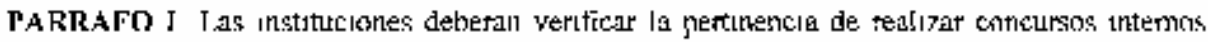

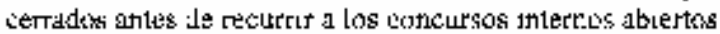

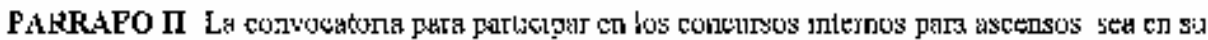

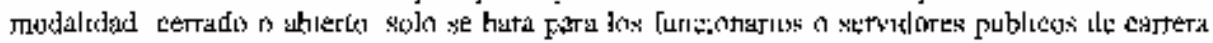
adrtonj:sitivit

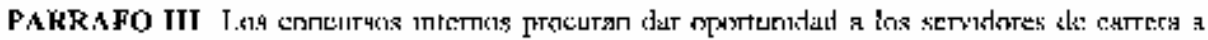
crever y desarrollare dentro del sistema de Carera

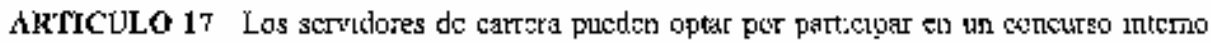

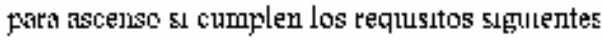

1! No posed nombremsento prorisonal

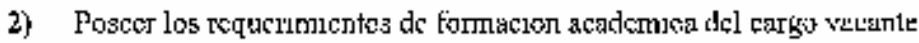




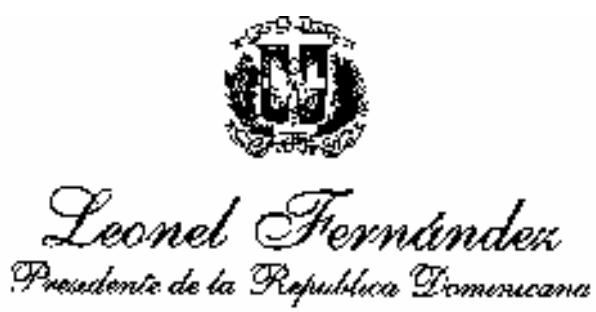

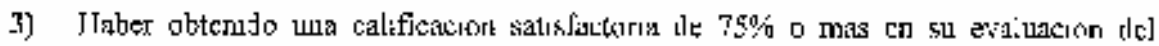
dersertipitio

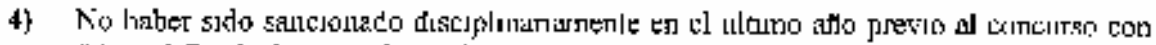
talca colı Ticates de scgundo grado

\section{DE LOS CONCURSOS EXTERYOS}

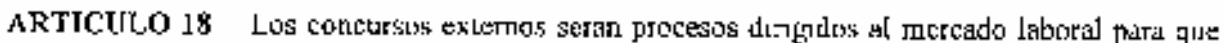

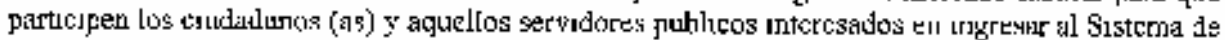

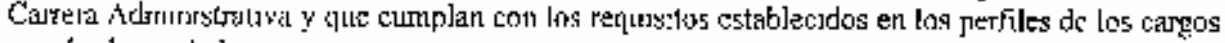
y en tas bases de lits esncutgos

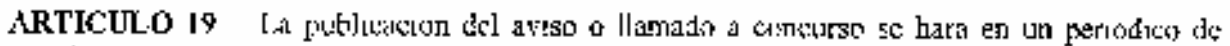

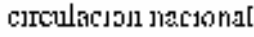

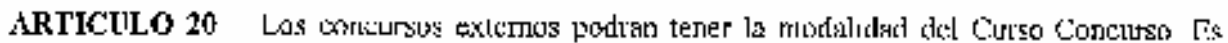

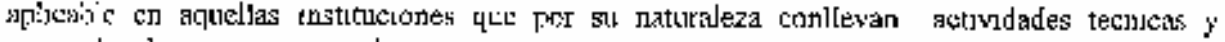

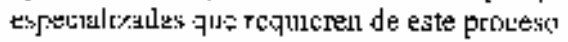

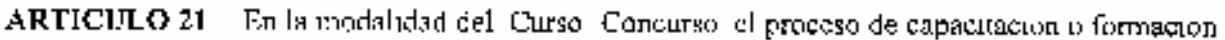

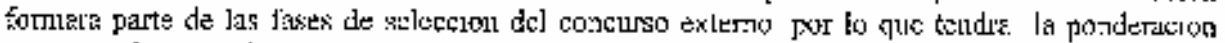
colropondustente en las hases dęl oncuso

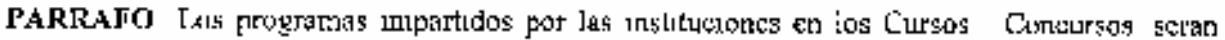

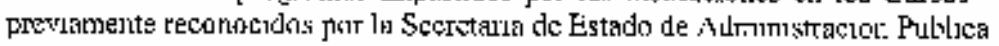

\section{DE LA PROGR 4WACION DE LOS CONCIRSOS}

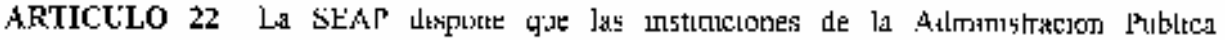

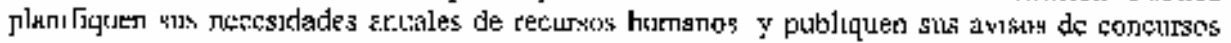

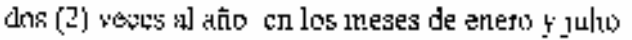

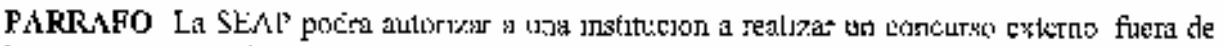

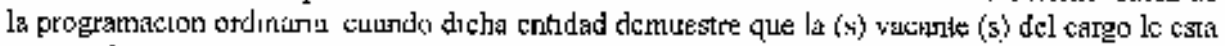

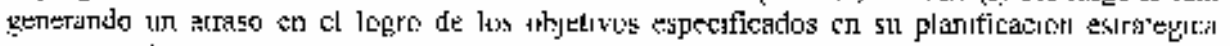
Irtst|cucirinst 


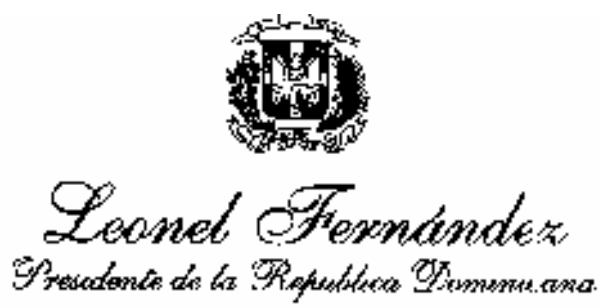

\section{DE. LAS CONYUCATORJAS Y PITRT.ICACTON DE LOS CONCUIROS}

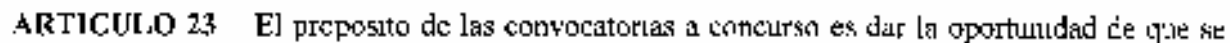

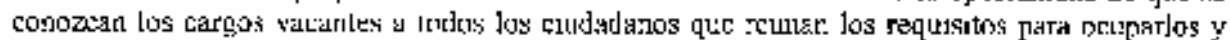

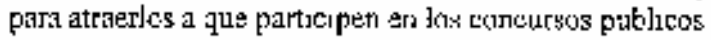

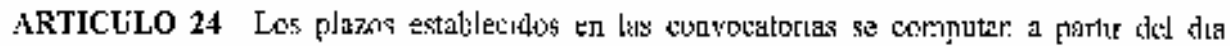

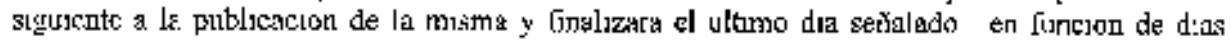

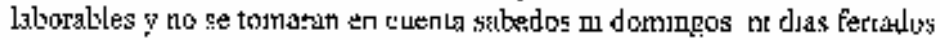

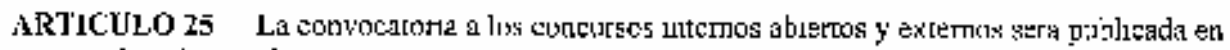

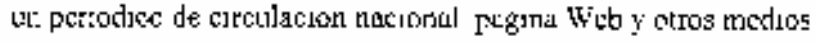

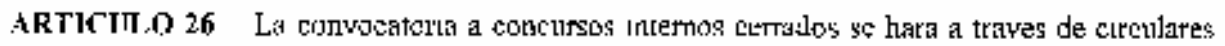
Fut_cason en liss murales intanct wointes sfiches

\section{DE LAS BASES UE LOS COYCLRSOS}

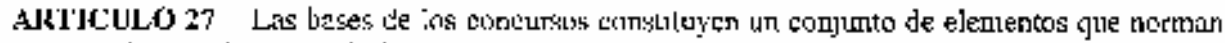

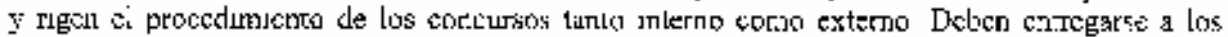

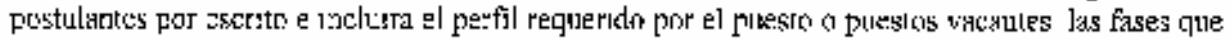

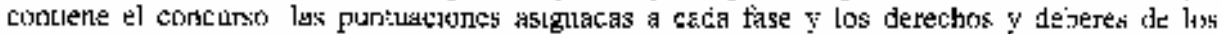

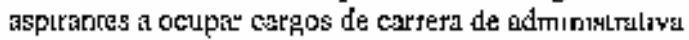

\section{THFL THADO DE LOS CONCURBOS}

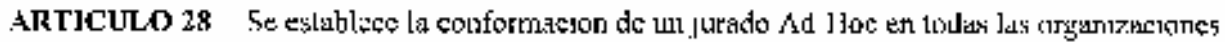

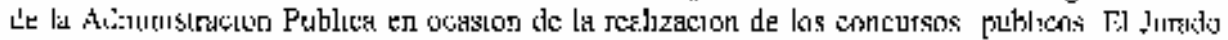

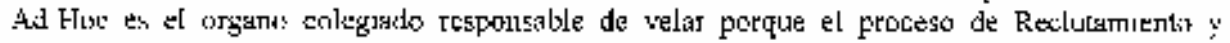

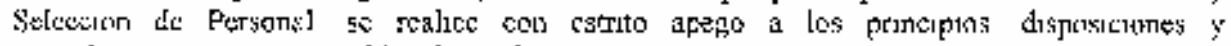

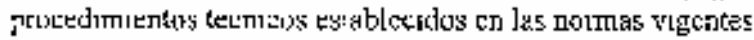

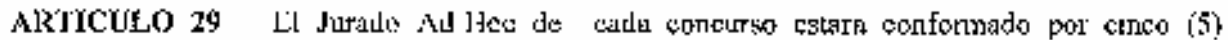

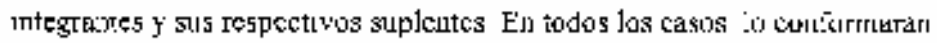




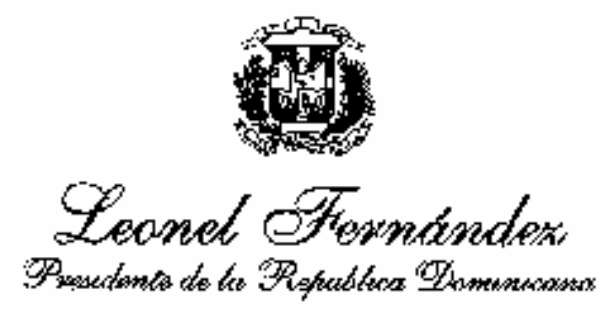

1 Fil litulat de la joststuch

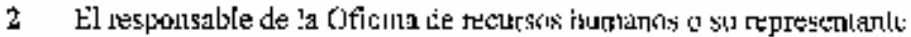

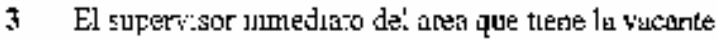

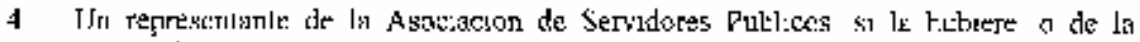
sociediat eıvil

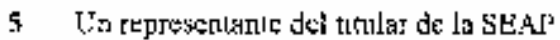

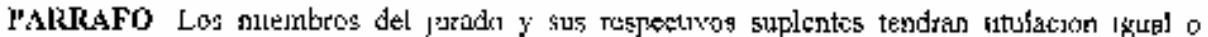

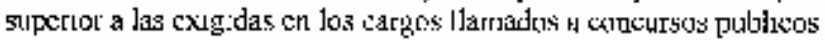

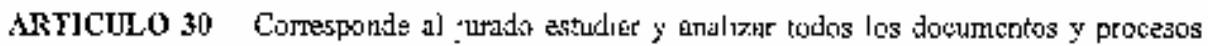

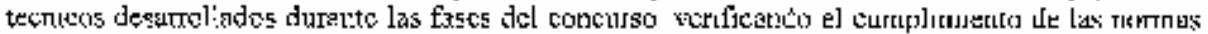

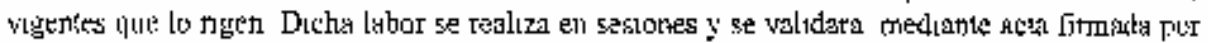
los tolegrantes del mismo

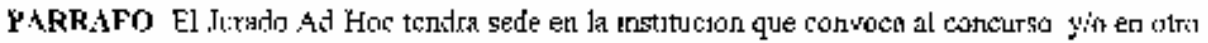

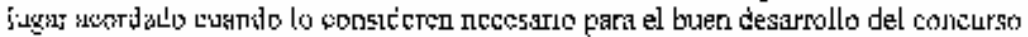

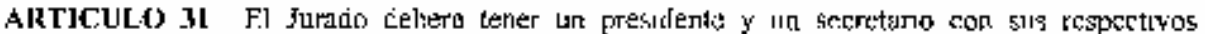

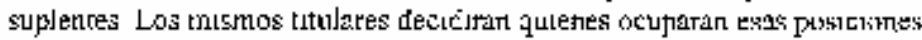

ARTICLLO 32 Comesponde al presidente del jurado ropesentir ail organo aooldar la

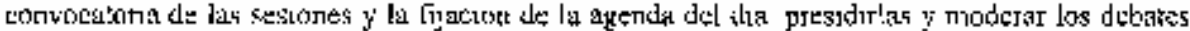

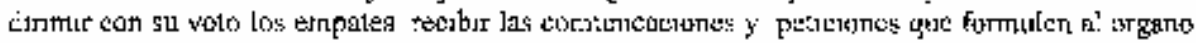

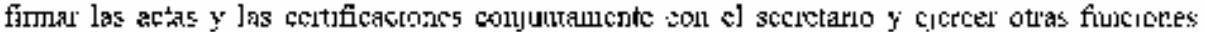

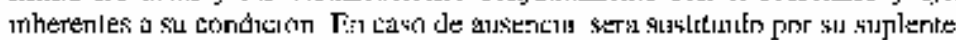

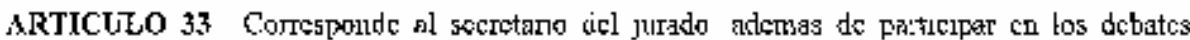

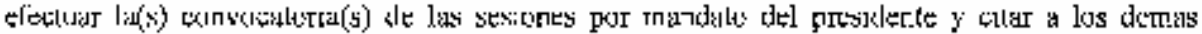

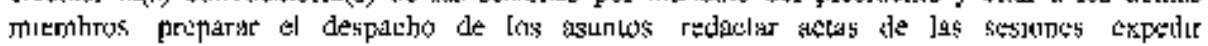

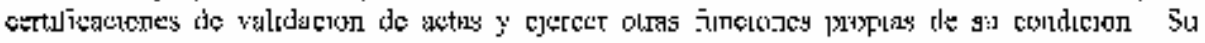

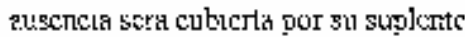




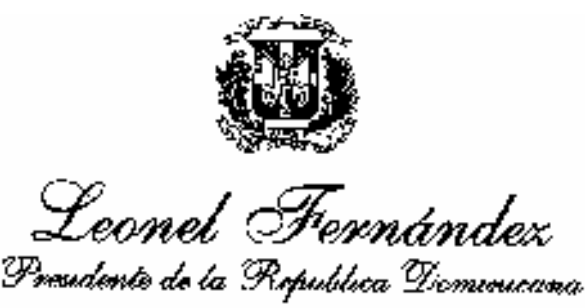

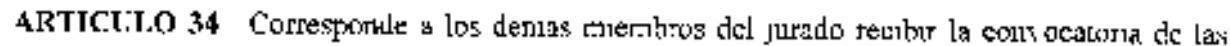

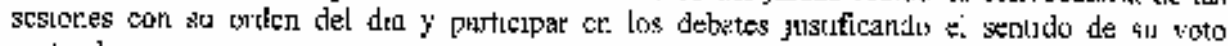
parıcit:ar

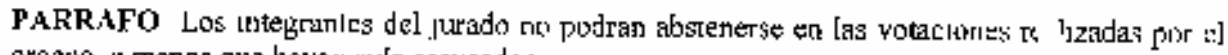
argigo u mecoos que hayar siclo recusados

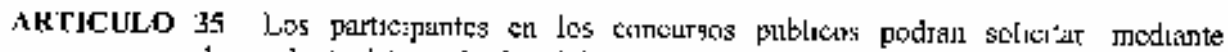

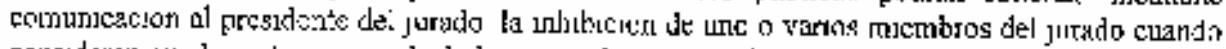

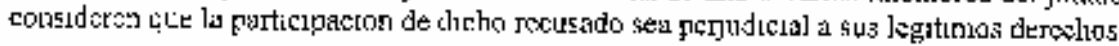

\section{Dए LAS FASTS DE SHLECCIOY}

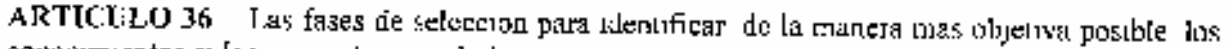

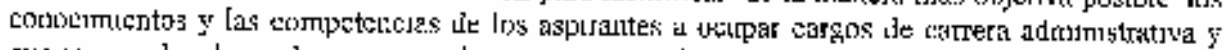

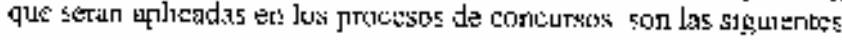

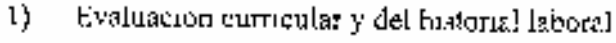

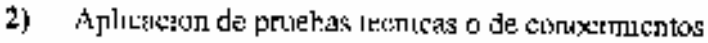

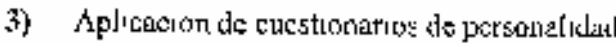

4) Aplicacion de prucbas de ejecucter de laborea

5) Presentacjon de proyering de taisa|a

6) Fentroristiaz de selerciol

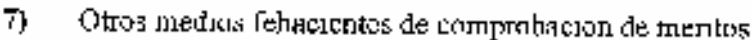

DF JA PONDFAACIOY DE LAS FASES DT SELECCION

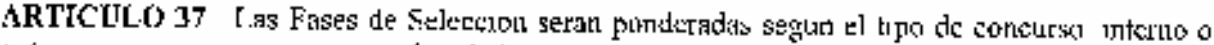

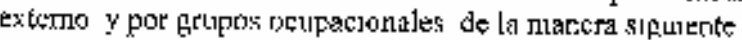

Comcienos Intirna: 
Fincs

I) Finm:Lipn hoademea

21 linaluarien de] Desempelto:

3) Pruebs Tecmo:

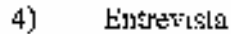

Concusas Extemos

$$
\text { Türie- }
$$

1) Forracion Achtemuca

2) Experichcid ]

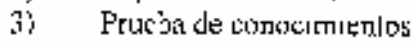

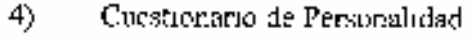

5) Fnlreviena

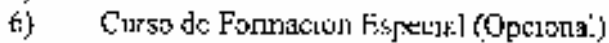

Panderyan

De $10 \%$ i $15 \%$

De 20 "li a 30 \%

Le 25" in a $35 \%$

Do $15 \%$ is $20 \%$

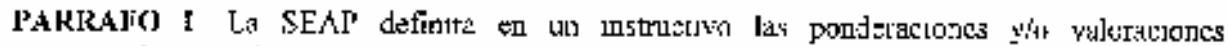

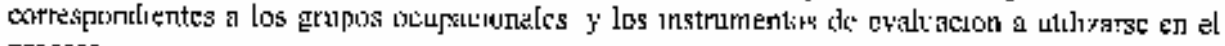
proceso

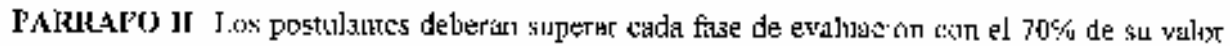

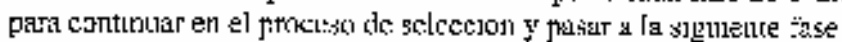

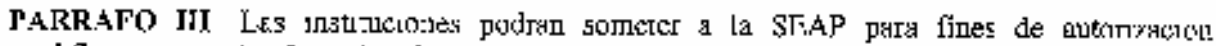

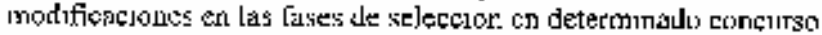

\section{DE LAS RORMLS PARA LA SEJECCIOY DE CANDTATOS}

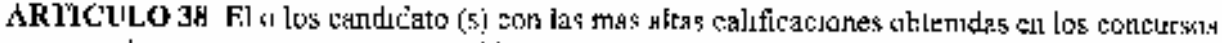

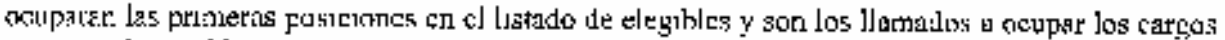

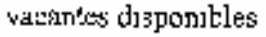

FARRAFO En caso de empate citse cos o mis candidatos con la misma puntugcion el ت

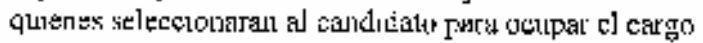




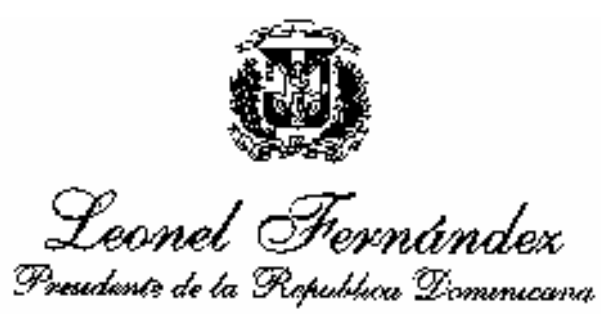

\section{THE LOS CONCLIROKS DECLARADOS DESIERTOS}

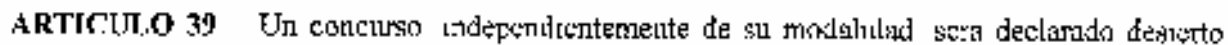
fer las fachnes nigurentes

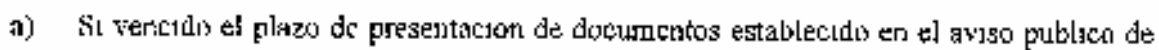

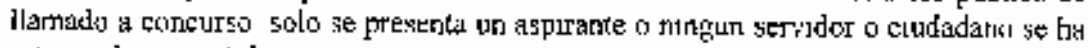
intereseco en postuj]

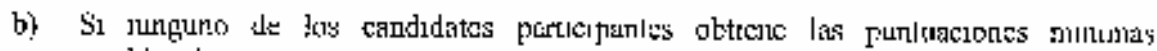
sotablecerdits

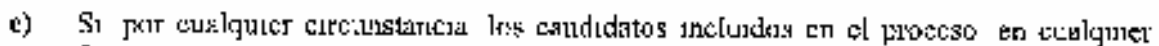

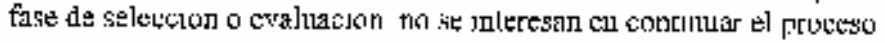

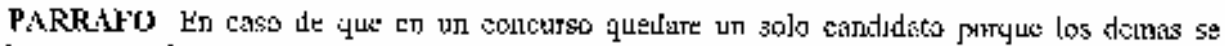

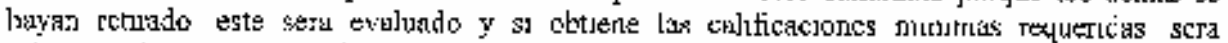
séecolonic para got par el sagrı

\section{JF IJOS CONCLRSOS DFCIARADOS YLLOS}

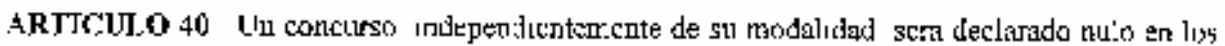

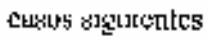

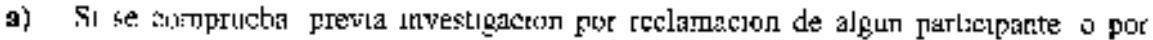

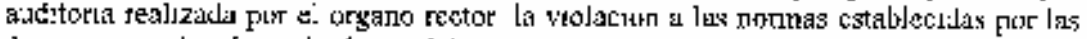

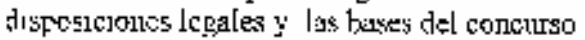

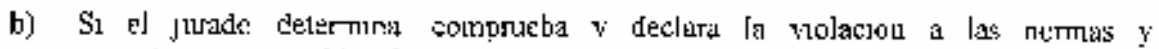

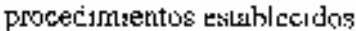

\section{DE LUS REITSTROS DF ELEGIBLES}

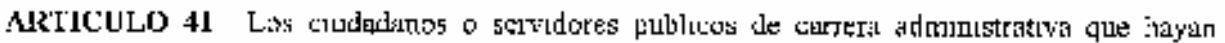

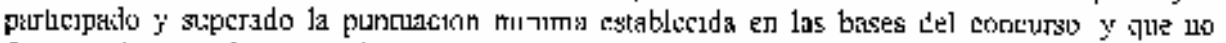

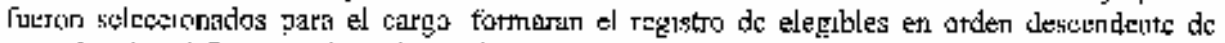

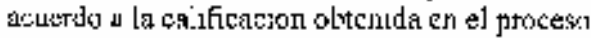




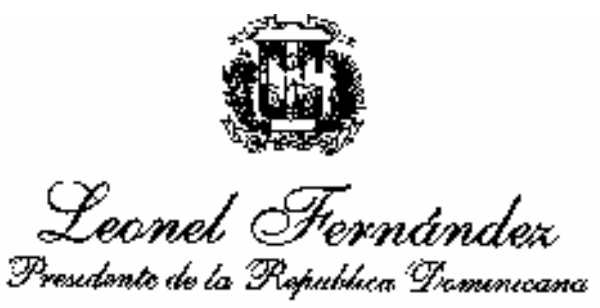

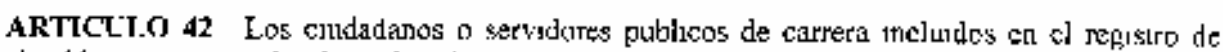
elegibles suth

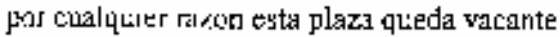

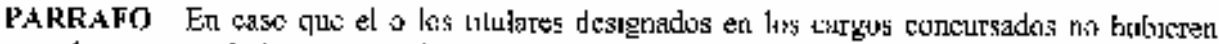

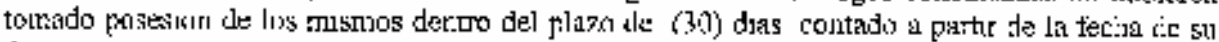

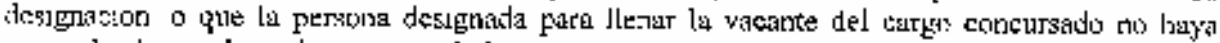

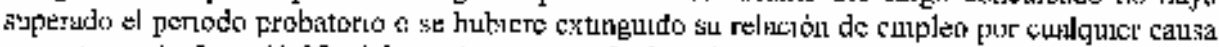

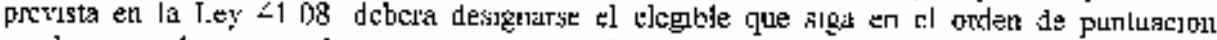

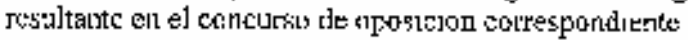

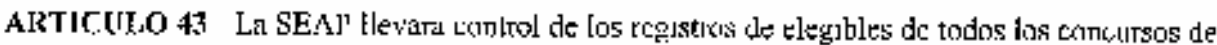

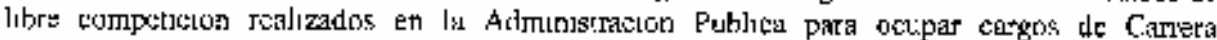

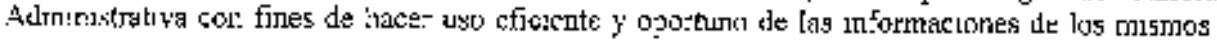

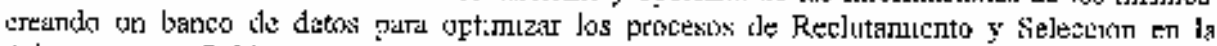
Mdrur':Blotentin Publea

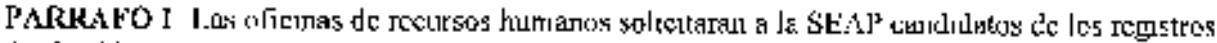
do cleghbles viderule;

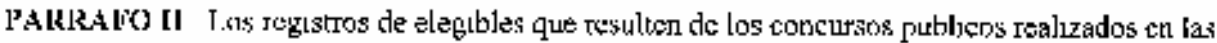

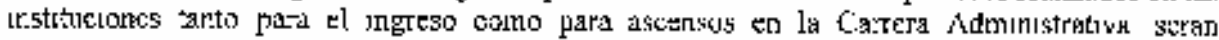

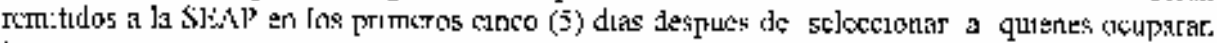

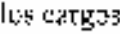

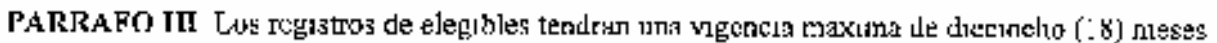

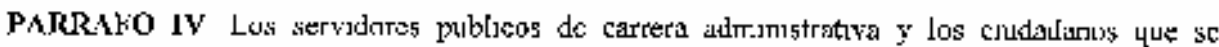

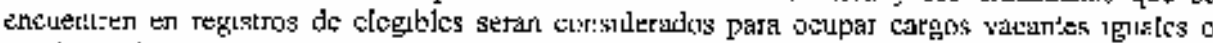

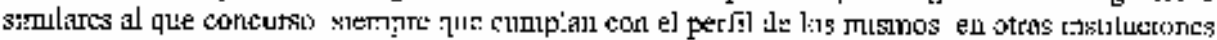

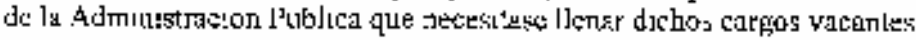

\section{CAPITLLO III}

\section{E: LOS MTRANISMOS DE MECLAHLAION}

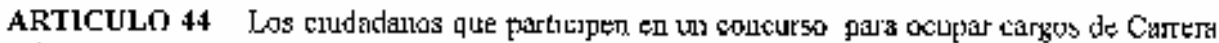

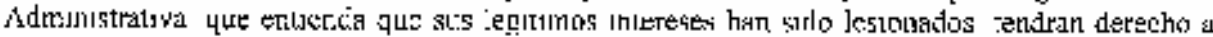




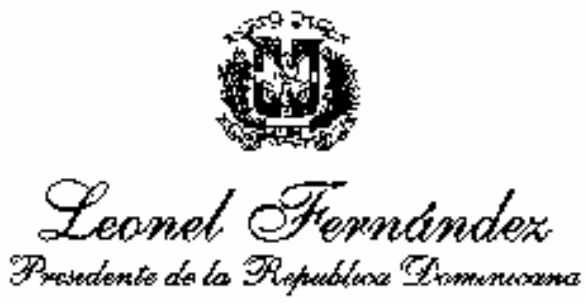

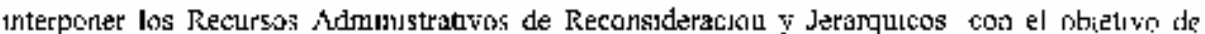

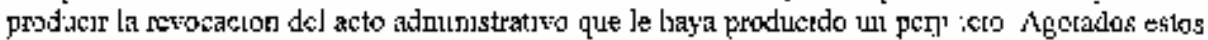

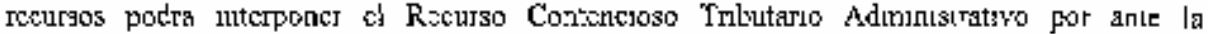

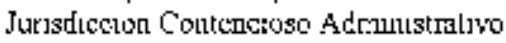

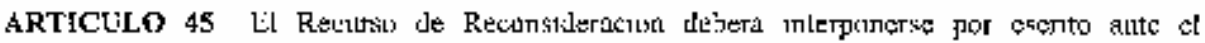

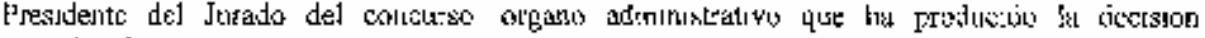

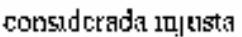

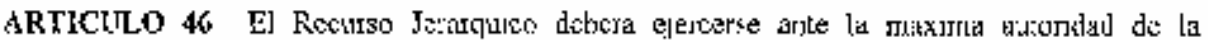

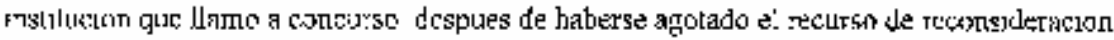

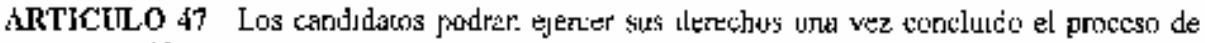
:

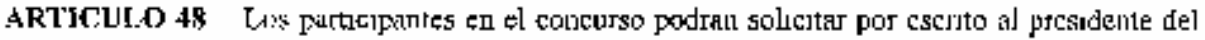

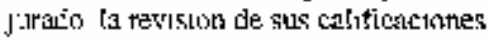

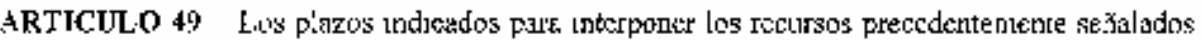

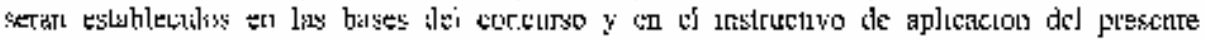
T:

\section{CAPJTELOTH}

\section{UE'L PLOCLSO UL INDEICCIOK}

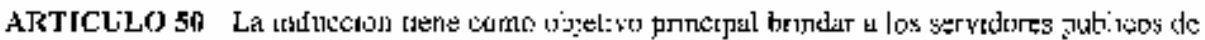

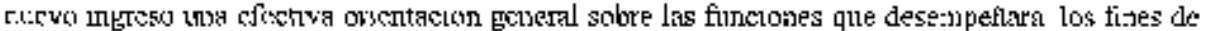

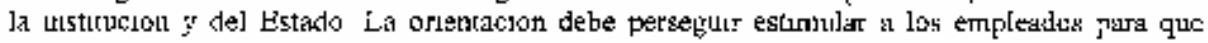

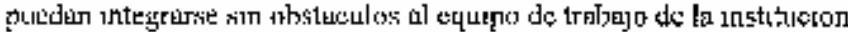

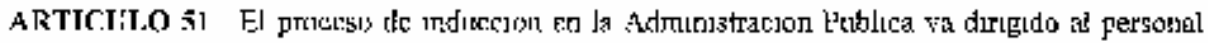

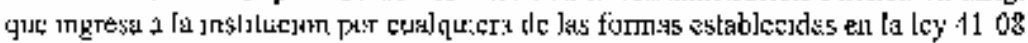

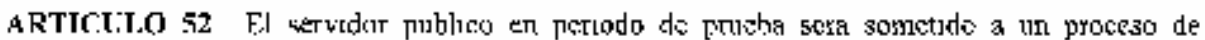
untusenon ol cual congtara de dos (2) fases

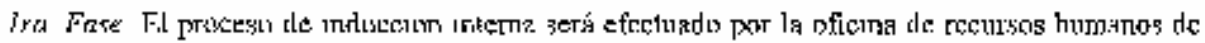

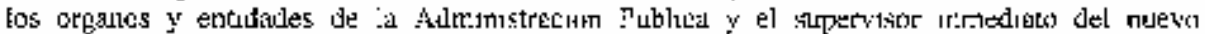
soluder donde se les dara a conocer 


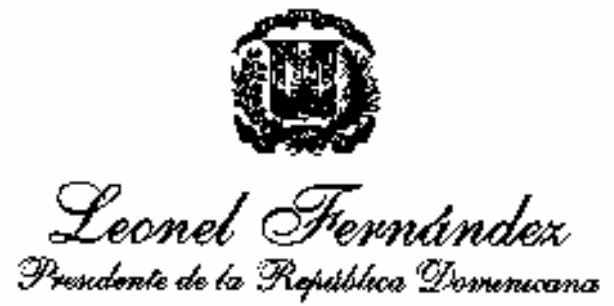

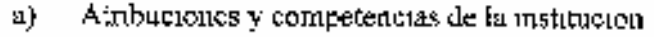

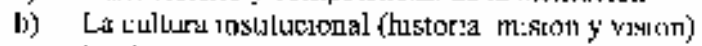

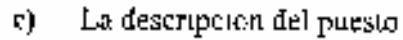

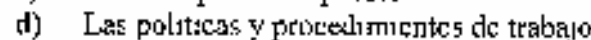

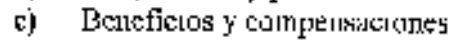

f) Replanento Jnterna

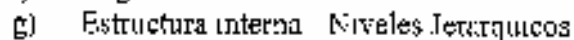

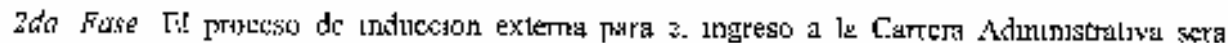

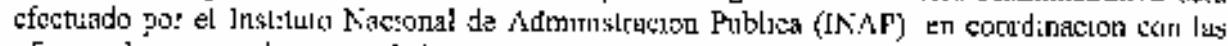

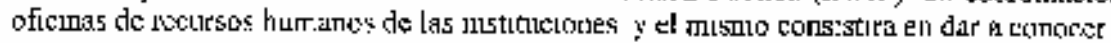

a) ITnะ yision general del liztad,

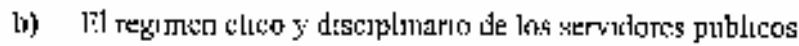

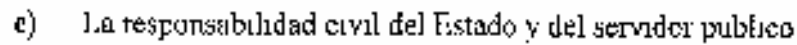

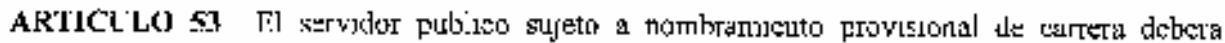

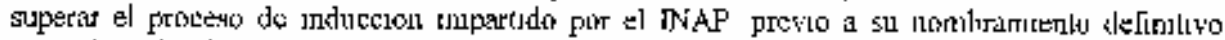

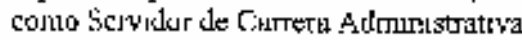

\section{CAPITULOY}

\section{LOS TIPOS DF. VOMRTAMILNTOS PARA CARCOS DL CAIHERA ADMUNISTKATIYA}

\section{DE LOS NOMERRA.HIE YTOS PROYLSIONAIFE EY PE.HIONO DE PRUEEA}

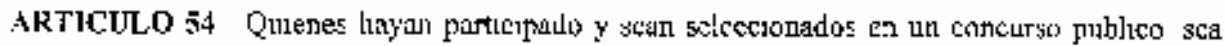

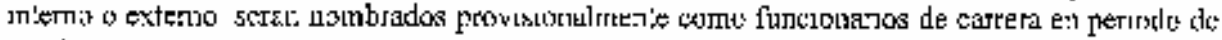
EmIL노ำ

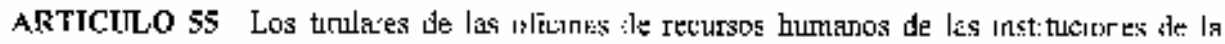

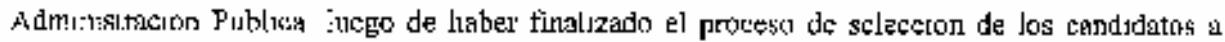

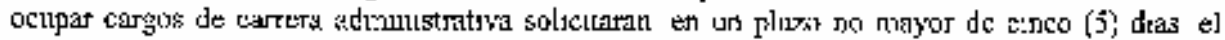

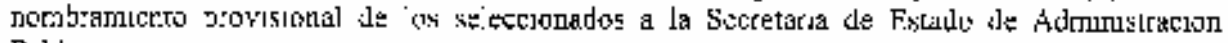
Publeca 


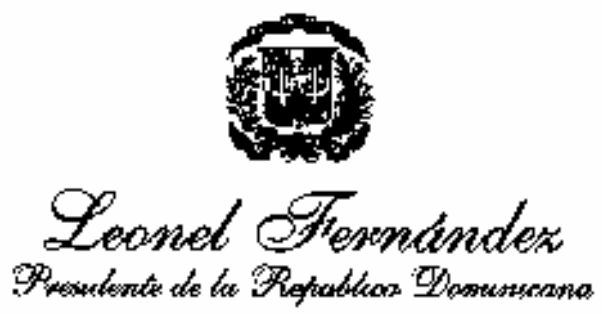

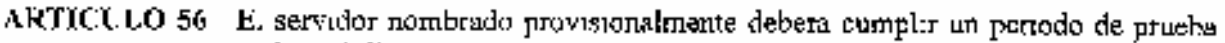

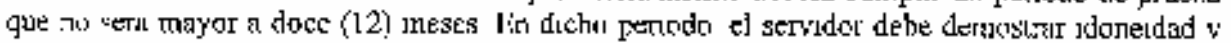

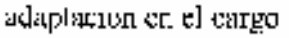

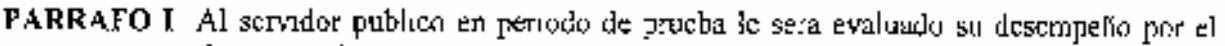

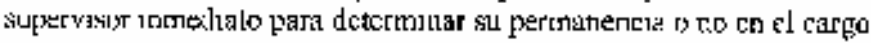

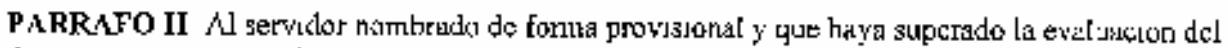

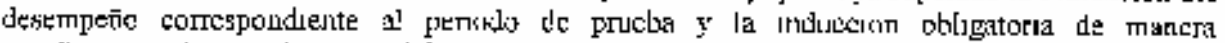

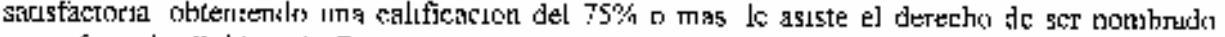
vomo Serrador Publico de Cumsta

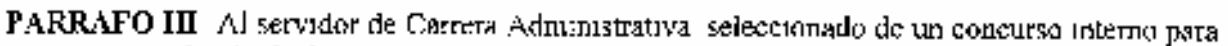

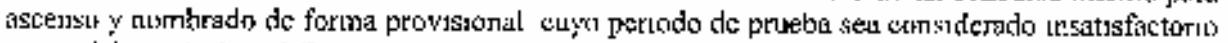

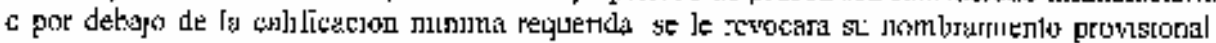

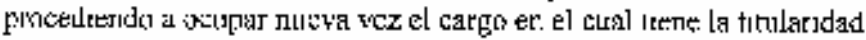

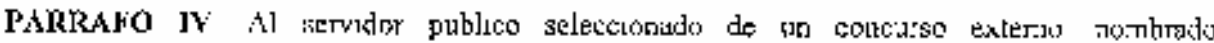

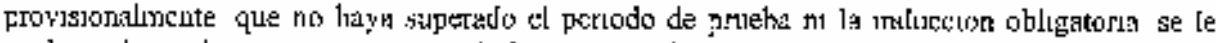

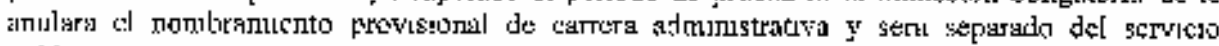
fublico

\section{DE LOS YUWHRAMIENTOS DE CARFERA}

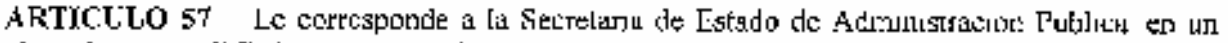

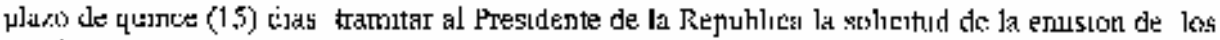

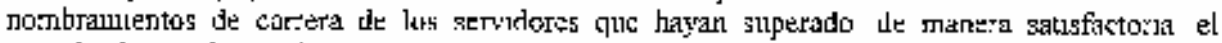

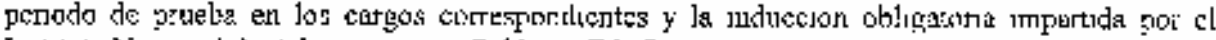

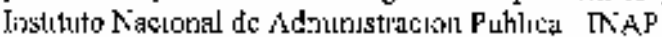

\section{DE LOS NOHARAHIFNTOS TFMPGRHLES}

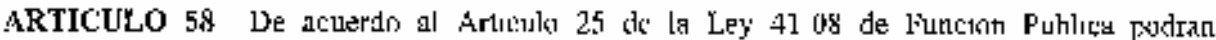

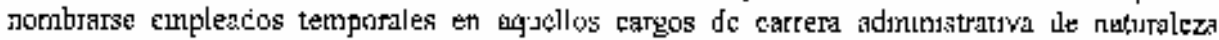

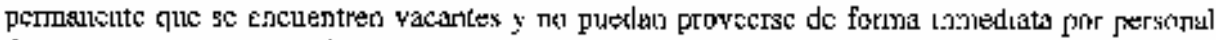

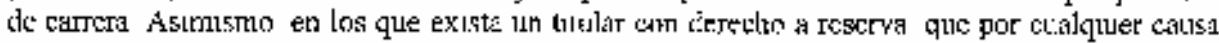

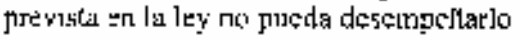




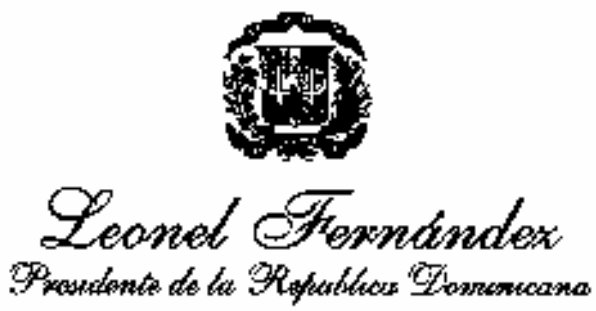

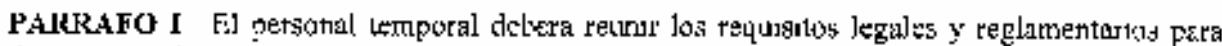

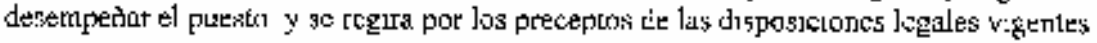

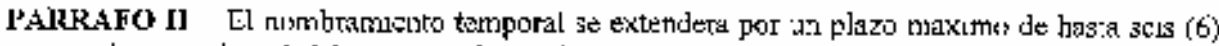

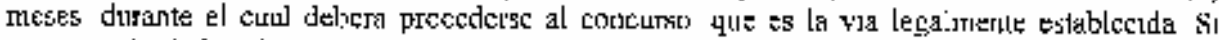

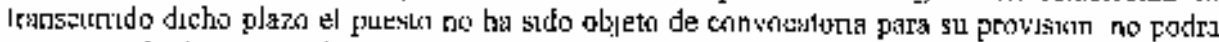

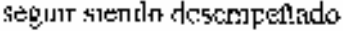

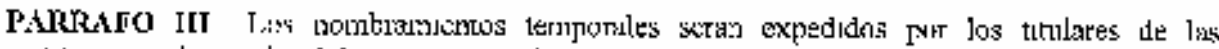

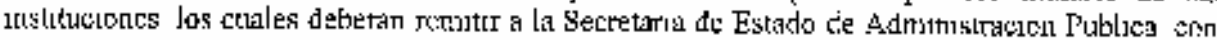

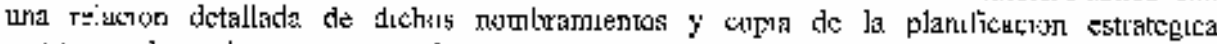

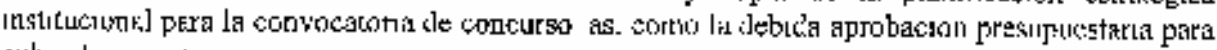
cutsir lit womile

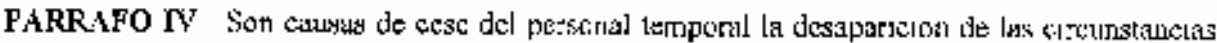

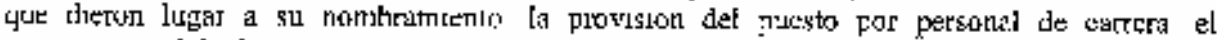

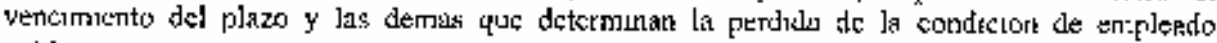
publists

\section{CAFITLIOOTI \\ DISPGSICIONTS FTMALS}

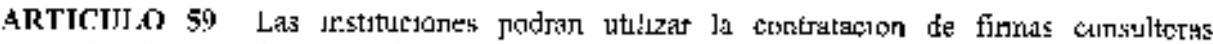

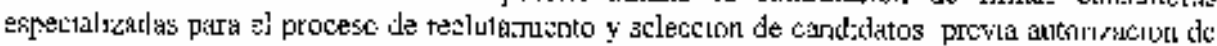

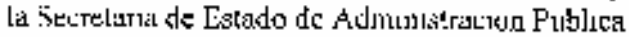

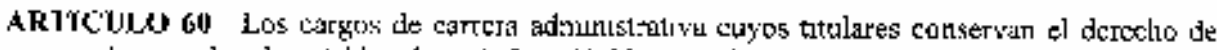

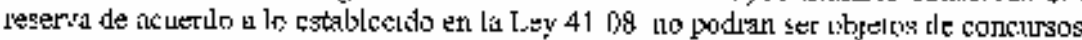

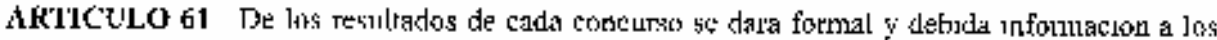

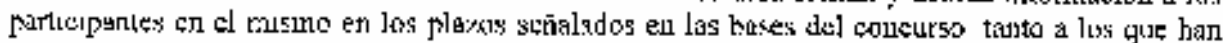

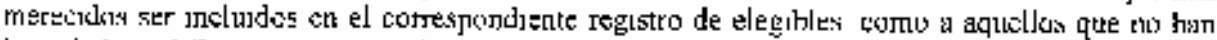

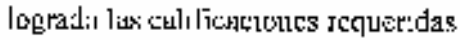

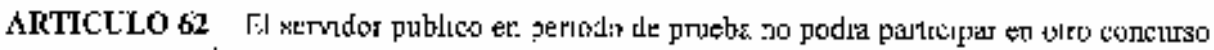

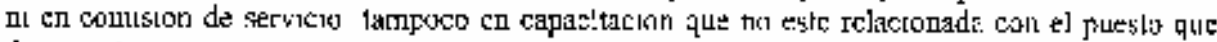
degcmipein 


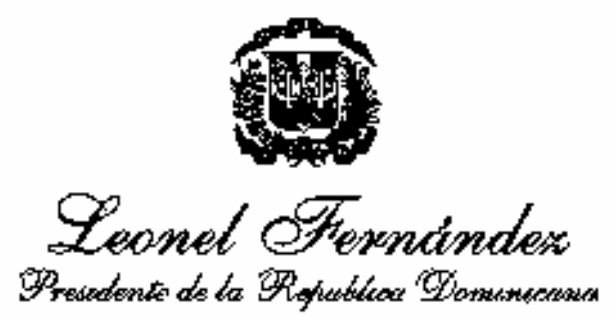

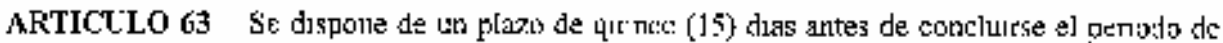

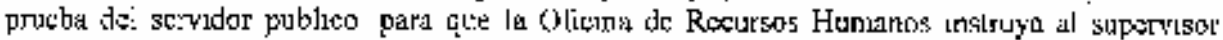

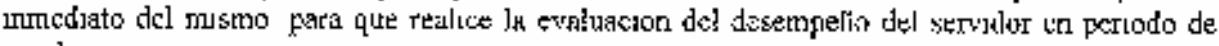
prusibs

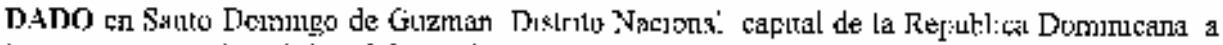

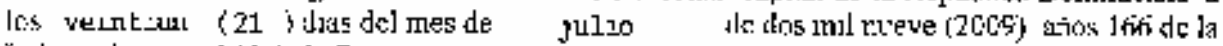

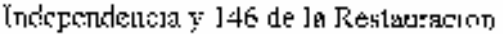

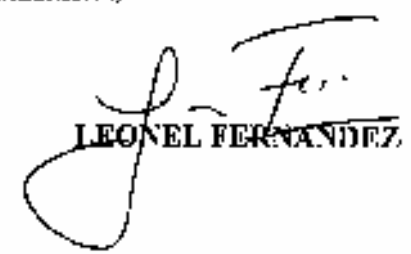

